2005

\title{
Law as Design: Objects, Concepts, and Digital Things
}

Michael J. Madison

Follow this and additional works at: https://scholarlycommons.law.case.edu/caselrev

Part of the Law Commons

\section{Recommended Citation}

Michael J. Madison, Law as Design: Objects, Concepts, and Digital Things, 56 Case W. Rsrv. L. Rev. 381 (2005)

Available at: https://scholarlycommons.law.case.edu/caselrev/vol56/iss2/5

This Article is brought to you for free and open access by the Student Journals at Case Western Reserve University School of Law Scholarly Commons. It has been accepted for inclusion in Case Western Reserve Law Review by an authorized administrator of Case Western Reserve University School of Law Scholarly Commons. 


\title{
LAW AS DESIGN: OBJECTS, CONCEPTS, AND DIGITAL THINGS
}

\author{
Michael J. Madison ${ }^{\dagger}$
}

\section{INTRODUCTION}

This is an Article about things in law. By "things" I mean tangible objects and intangible concepts, invisible physical substances and intangible "virtual" things, the Roman res and the common law chattel personal, and the colloquial "thing." It is an inclusive, elastic definition, not a strict one, and I use the word "thing" conscious of its lack of rigor. ${ }^{1}$ I do so for a simple reason. Things are important to the

$\dagger$ Associate Professor, University of Pittsburgh School of Law. Email: madison@law.pitt.edu. Copyright (C) 2005 Michael J. Madison. Earlier versions of this paper were presented to the 2003 Annual Meeting of the American Intellectual Property Law Association; the 2004 Intellectual Property and Communications Law Scholars Roundtable at Michigan State University College of Law; a faculty colloquium at the University of Pittsburgh School of Law; the 2004 Annual Meeting of the Law and Society Association; and the Fourth Annual Intellectual Property Scholars Conference, hosted by the DePaul University College of Law. Thanks to participants at each for invaluable comments and suggestions. Thanks as well to Barton Beebe, Tom Cotter, Brett Frischmann, James Gibson, Sonia Katyal, Jay Kesan, Adam Mossoff, Josh Sarnoff, Gordon Smith, and George Taylor for comments, counsel and encouragement, and to some improbable sources of insight on legal scholarship—Jeff Brenzel, Niles Eldredge, Natalie Jeremijenko, Carl Johnson, Peter Kindlmann, and Peter Machamer-for their suggestions.

1 Bill Brown notes the obscure character of the term "thing" itself, "both at hand and somewhere outside the theoretical field, beyond a certain limit, as a recognizable yet illegible remainder or as the entifiable that is unspecifiable. Things lie beyond the grid of intelligibility the way mere things lie outside the grid of museal exhibition, outside the order of objects." Bill Brown, Thing Theory, 28 CRITICAL INQUIRY 1, 5 (2001). Others are more precise. See, e.g., MARCEL MAUSS, THE GIFT: THE FORM AND REASON FOR EXCHANGE IN ARCHAIC SOCIETIES 50 (W.D. Halls trans., 1990) (1925) (identifying "thing" with the Roman res); E.J. Lowe, Things, in The OXFORD COMPANION TO PHILOSOPHY (1995) ("'Thing', in its most general sense, is interchangeable with 'entity' or 'being' and is applicable to any item whose existence is acknowledged by a system of ontology, whether that item be particular, universal, abstract, or concrete."); Frederick Pollock, What Is a Thing?, 10 L.Q. REV. 318, 318-21 (1894) (describing a thing variously as "whatever can be separately perceived," what is "distinct and measurable," what is "recognized by the usage of mankind," and that "which can, in the widest sense, be owned"). Though most definitions distinguish between the object and its representation, Carol Rose suggests that these are one and the same. Things are both what we see, and what we describe. Things are stories. See CAROL M. ROSE, Seeing Property, in PROPERTY AND PERSUASION: ESSAYS ON THE HISTORY, THEORY, AND RHETORIC OF OWNERSHIP 267, 285-89 (1994); cf. Thomas J. Palmeri \& David C. Noelle, Concept Learning, in THE HANDBOOK OF 
law in ways that cross disciplinary boundaries and engage multiple theoretical perspectives. The law has no all-purpose theory of things. But it should. ${ }^{2}$ This Article is a step in that direction.

Things change. For the most part, though, until very recently, the law has accepted things as given. The question has been what to do with them. As the Legal Realists taught us, the answer generally has been that the law deals with rights and, specifically, with rights between people, not rights in things. ${ }^{3}$ Thingness is prior. The law is post. That sequence appears to be changing. Law and thingness emerge together in a variety of ways that I describe below. Property theorists have recently raised the problem of things in the law, recognizing the paradox that in an era of increasing dephysicalization of the artifacts of our lives, thingness may matter more than ever. ${ }^{4}$ Similar expressions of concern are part of contemporary discourse in intellec-

Brain Theory and Neural Networks 252 (M.A. Arbib ed., 2003) (discussing "concepts" as fundamental building blocks of human knowledge); Stephen Laurence \& Eric Margolis, Concepts and Cognitive Science, in CONCEPTS: CORE READINGS 3 (Stephen Laurence \& Eric Margolis eds., 1999) (same).

2 My project echoes recent thing inquiries in other disciplines. See BLL. BROWN, A SENSE of Things: THE OBJeCt MATTER OF AMERICAN LITERATURe (2003) (exploring America's fascination with things and the difficulty American literature had in dealing with objects at the turn of the century); LEARNING FROM THINGS: METHOD AND THEORY OF MATERIAL CULTURE STUDIES (David Kingery ed., 1996) (gathering works from diverse scholars and emphasizing the importance of a multidisciplinary approach for analyzing objects); MATERIAL CULTURES: Why SOME ThINGS MATTER (Daniel Miller ed., 1998) (collecting essays showing how artifacts illustrate social values and contradictions); THINGS (Bill Brown ed., 2004) (collecting essays by scholars from diverse fields inquiring into the nature and importance of things); Andreas Reckwitz, The Status of the "Material" in Theories of Culture: From "Social Structure" to "Artefacts," 32 J. THEORY SOC. BEHAVIOR 195 (2002) (analyzing the role of material objects in social theories).

3 See A.M. Honoré, Ownership, in OXFORD EsSAYS IN JURISPRUDENCE 107, 128-30 (A.G. Guest ed., 1961) (expressing skepticism that thing is a useful construct for investigating ownership).

4 See Anita Bernstein, The Representational Dialectic (With Illustrations from Obscenity, Forfeiture, and Accident Law), 87 CAL. L. REV. 305, 310 (1999) ("[T] he physical object occupies an unbudging place in legal doctrine." (citing Rosemary J. Coombe, The Cultural Life of Things: Anthropological Approaches to Law and Society in Conditions of Globalization, 10 AM. U. INT'L J. L. \& POL'Y 791 (1995))); C.M. Hann, Introduction: The Embeddedness of Property, in PROPERTY RELATIONS: RENEWING THE ANTHROPOlOGICAL TRADITION 1 (C.M. Hann ed., 1998); Michael A. Heller, The Boundaries of Private Property, 108 YALE L.J. 1163 (1999); Clarisa Long, Information Costs in Patent and Copyright, 90 VA. L. REV. 465, 474 (2004); Thomas W. Merrill \& Henry E. Smith, What Happened to Property in Law and Economics?, 111 YALE L.J. 357, 359, 384-85 (2001); J.E. Penner, The "Bundle of Rights" Picture of Property, 43 UCLA L. REV. $711,799-818$ (1996); Rose, supra note 1, at 269, 282 n.59; Jeanne L. Schroeder, Death and Transfiguration: The Myth that the U.C.C. Killed "Property," 69 TEMP. L. REv. 1281, 1285-86 (1996); Emily Sherwin, Two-and Three-Dimensional Property Rights, 29 ARIZ. ST. L.J. 1075, 1086 (1997); Timothy P. Terrell \& Jane S. Smith, Publicity, Liberty, and Intellectual Property: A Conceptual and Economic Analysis of the Inheritability Issue, 34 EMORY L.J. 1, 25-32 (1985). The notion of property as relations between persons with respect to things derives from Kant. See IMMANUEl KANT, THE METAPHYSICS OF MORALS 49-86 (Mary Gregor ed. \& trans., 1996) (1785). 
tual property law (the continuing role of first sale and exhaustion doctrines, for example), in commercial law (the law of software licensing and of secured financing, for example), and in antitrust law (in the question of allegedly anticompetitive marketing restrictions, such as tying, for example). The concern is largely inchoate. Scholars and courts struggle to apply the traditional sequence (thing first, law second) to the new, integrated order. They have had only modest success. We ought to be asking a different set of questions and seeking a different set of answers. We ought not to focus exclusively on rights in things. Instead, to assure that we have a regulatory toolkit of appropriate scope, we should examine the origins of things. My question is the cousin of the philosopher's "What is a thing?"5 In law, where and how do we find things? What makes a thing a thing? ${ }^{6}$

Traditionally, the notion of the "legal" thing has been practically and conceptually distinct from the "real" thing. In patent law, for example, there is the actual device that the inventor developed, and there is the legally distinct thing that the patentee owns, which the law knows as the patent claim. In the Hart/Fuller debate over the hypothetical "No vehicles in the park," the question was which "actual" things should be treated as legal "vehicles" for purposes of the rule.

5 The philosopher E.J. Lowe distinguishes four uses of "is":

the 'is' of attribution ('Socrates is wise', 'Grass is green'), the 'is' of identity ('Napoleon is Buonaparte', 'Water is H20'), the 'is' of instantiation ('Mars is a planet', 'A horse is a mammal'), and the 'is' of constitution ('This ring is gold', 'A human body is a collection of cells').

E.J. LOWE, KINDS OF BEING: A STUdY IN INDIVIDUATION, IDENTIrY AND THE LOGIC OF SORTAL TERMS 3 (1989). Lowe argues that the "is" of identity and instantiation are logically more fundamental than the others. Id. at 4, 28-42. He also notes the "is" of existence, though he argues that there are not different kinds of existence, but only different kinds of things that exist. Id. I visit the ontological question in Part III.

6 Conceptually similar efforts to comprehend the legitimacy and authority of concepts and objects by analyzing how they are produced include Jay P. Kesan \& Rajiv C. Shah, Deconstructing Code, 6 YALE J.L. \& TECH. 277 (2003-2004); Douglas A. Kysar, Preferences for Processes: The Process/Product Distinction and the Regulation of Consumer Choice, 118 HARV. L. REV. 525 (2004); Katrina Miriam Wyman, From Fur to Fish: Reconsidering the Evolution of Private Property, 80 N.Y.U. L. REV. 117 (2005); see also Landgon Winner, Upon Opening the Black Box and Finding It Empty: Social Constructivism and the Philosophy of Technology, 18 SCI., TECH., \& HUM. VALUES 362, 368-73 (1993) (critiquing the absence of evaluation in social constructivist literature and noting that what a thing is matters).

7 On the Hart/Fuller debate in contemporary context, see Steven L. Winter, Transcendental Nonsense, Metaphoric Reasoning, and the Cognitive Stakes for Law, 137 U. PA. L. REV. $1105,1172-80$ (1989). The debate is significant in itself, and I return to it in Part III. Focusing on its linguistic implications at times obscures its connection to an underlying disagreement over the relationship of systems of law to morality and over criteria for judging those systems. In Hart's framework, law responded to the world (that is, the world as it is, in its core sense), and people responded to the law. A thing, then, was what people used and experienced. Moral judgments came later. See H.L.A. Hart, Positivism and the Separation of Law and Morals, 71 HARV. L. REV. 593 (1958). Fuller replied that the relationship between law and morality was more complex, even interdependent, and he insisted, accordingly, that the understanding of a legal thing depended not only on its context, but also on its purpose. Lon L. Fuller, Positivism 
At the margins, there are exceptions to the law's sense of taking real things for granted. At the margins, things may be regulated for health and safety purposes. ${ }^{8}$ But this is the exception, rather than the rule. On the whole, if we encounter problems with real things, we leave them alone. We regulate what people do.

As I describe in more detail in the next Part, "real" things and "legal" things are increasingly blended. ${ }^{9}$ The authority of the real thing and the authority of the legal thing overlap to the point of being indistinguishable. Real things can be manipulated just as we can manipulate legal things (leading to the suspicion, common to philosophers and physicists for a much longer time, that real things are more manipulable than they seem). ${ }^{10}$ Legal things are increasingly taken for granted. Copyrights and patents, for example, are increasingly seen as perfectly robust and self-evident things that justify their own scope.

and Fidelity to Law-A Reply to Professor Hart, 71 HARV. L. REv. 630, 663 (1958).

8 Examples include regulation of telecommunications facilities to assure consumer access to emergency services, access for law enforcement purposes, and access for disabled users. Jay P. Kesan \& Rajiv C. Shah, Shaping Code, 18 HARV. J.L. \& TECH. 319, 338 (2005). Kesan and Shah include these among what they characterize as "numerous" examples of "technologyforcing regulation." Id. That category, however, includes examples of regulation intended to prompt technological development, as well as design mandates themselves.

9 The philosopher W.V.O. Quine argued that the notions of the analytic (the "real" or the "true") and the synthetic (the "manufactured") express two points on a continuum. See W.V.O. QUINE, Ontological Relativity, in ONTOLOGICAL RELATIVITY AND OTHER ESSAYS 26 (1969) [hereinafter QUINE, Ontological Relativity] (specifying the circularity of any alleged universal ontology of kinds); W.V.O. QUINE, Two Dogmas of Empiricism, in FROM A LOGICAL POINT OF VIEW 20 (2d ed., 1961) [hereinafter QUINE, Two Dogmas of Empiricism].

As an empiricist I continue to think of the conceptual scheme of science as a tool, ultimately for predicting future experience in light of past experience. Physical objects are conceptually imported into the situation as convenient intermediaries-not by definition in terms of experience, but simply as irreducible posits comparable, epistemologically, to the gods of Homer.

Quine, Two Dogmas of Empiricism, supra, at 44. "The myth of physical objects is epistemologically superior to most in that it has proved more efficacious than other myths as a device for working a manageable structure into the flux of experience." Id. Thus the question is to describe the truth or falsity of statements rather than to prove the existence of things or objects themselves. Bruno Latour later articulated a related thesis, that modernity imposed an artificial distinction between inanimate objects and human subjects, in BRUNO LATOUR, WE HAVE NEVER BEEN MODERN 10-1 1 (Catherine Porter trans., 1993) (1991). See also THEODOR W. ADORNO, NEGATIVE DialectiCs 189-94 (E.B. Ashton trans., 1973) (1966) (arguing against the subordination of the object in traditional epistemology and phenomenology).

${ }^{10}$ Thus the lament, "Things are seldom what they seem, Skim milk masquerades as cream; Highlows pass as patent leathers; Jackdaws strut in peacock's feathers." W.S. GILBERT \& ARTHUR SUlLIVAN, Things Are Seldom What They Seem, in H.M.S. PINAFORE (first performed May 25, 1878). A related claim has been made by legal scholars. See Dan Hunter, $C y$ berspace as Place and the Tragedy of the Digital Anticommons, 91 CAL. L. REV. 439, 442-46 (2003); Mark A. Lemley, Place and Cyberspace, 91 CAL. L. REV. 521, 523-25 (2003) (both describing the inadequacies of "real space" metaphors to capture interests in cyberspace legal disputes). 
Patents are explained via reference to ordinary dictionaries. ${ }^{1}$ Copyright infringement is characterized as "stealing." 12

As this line blurs, it makes sense to blend the tools of real-thing analysis and legal-thing analysis, that is, to think about legal things using the tools developed for real things (Where do they come from? Are they real? How do we know them?) and to think about real things using tools for legal things (What is the character of their legitimacy and authority?). One way to do this might be to examine how changes to real things do and should influence the constitution of legal things: What limits should exist on the regulation of real things? But this understates the contingent character of real things. I suggest that we should interrogate the construction of things more generally. The transition from legal thing to real thing, and the reverse, is often transparent or automatic. To focus on one without likewise analyzing the other is to tell only half the story. We have for centuries been concerned with the two questions of existence and identity ("What is real?" and "What is not?"13). It may be time for the law to recognize that these are not necessarily two questions, but one.

I borrow observations from metaphysics, epistemology, semantics, social psychology, and sociology, among other disciplines, but without "doing" any of them. Philosophers, linguists, and other social scientists may not sanction this method. ${ }^{14}$ The method is, by contrast, a presentation of how themes in those disciplines are recognized by the law, as the law borrows them and simplifies them for its purposes, with much of the intellectual messiness that often characterizes the legal system. "Things" are classically understood as instances, tokens, or artifacts of a particular category, and the classical question seeks the criteria or conditions that qualify this thing for membership. What conditions characterize the category? Does this thing possess those conditions? A variety of intellectual traditions have investigated this question; we have philosophical "realists" and "idealists," empiricists and pragmatists, materialists and constructivists. There is the linguistic turn, focusing on the relationship between the thing and language. All of these traditions, in one way or another, argue that the sources of evidence for this question are more or less objective and

1 See Phillips v. AWH Corp., 415 F.3d 1303, 1318 (Fed. Cir. 2005) (en banc) (approving use of dictionaries in claim construction); Joseph Scott Miller \& James A. Hilsenteger, The Proven Key: Roles and Rules for Dictionaries at the Patent Office and the Courts, 54 AM. U. L. REV. 829 (2005).

12 See Jessica Litman, Sharing and Stealing, 27 HaStings COMM. \& ENT L.J. 1 (2004).

13 See Walter Benjamin, The Work of Art in the Age of Mechanical Reproduction (1936), in LLLUMINATIONS 217 (Hannah Arendt ed. \& Harry Zohn trans., 1968).

14 I acknowledge the risk of criticism for disciplinary abuse. See Brian Leiter, Intellectual Voyeurism in Legal Scholarship, 4 YALE J.L. \& HUMAN. 79, 80 (1992). 
are more or less broad. Some would look to the essential properties of the category and to the presence or absence of those properties in the thing. Some would look to the function of the thing, or its purpose, or its use, or to its role in linguistic or other social conventions, patterns, or practices. Others would look to the relationship between the thing and prototypical tokens, and still others would look to the relationship between the thing and known exemplars. Some traditions deny the objectivity of the question itself. For reasons philosophical or empirical, categories may be as contingent as their conditions of satisfaction.

Investigating and applying each of these methods to the law would take volumes, and I have only a handful of pages. Fortunately, the law is neither so diverse nor so methodologically precise. There are, I believe, five basic approaches to things represented in various legal traditions, each of which borrows bits and pieces from the foregoing inventory. One approach is the ontological sense of things. Things are real and independent of the legal system (thing-by-nature). ${ }^{15}$ They are defined by their (equally real) properties. The task for legal institutions is to define those properties and then to investigate in a particular dispute whether those properties are present. Alternatively, things may be constituted, that is, they are not "real" in an antecedent sense. Things are not found. They are made. The question is how. They may be made by their makers (thing-by-design). They may be made via private bargains (thing-by-contract). They may be made via some social process or practice (thing-by-practice). Or things may be made by law, purely as a function of public policy (thing-by-policy). Law itself may make the things that society needs and wants.

If we look at thingness in this light, the implications of the analysis become clearer. Moving from beginning (things as found by law) to end (things as constituted by law), we can see that options for regulating thingness move from few to many. A system that treats things as independent and fixed has little choice but to recognize things and to

is Of course, before we wonder about their origins and significance, we need to be sure that things exist. Philosophers do not take the answer for granted. Though they do not quite argue (any longer) that things do not exist, there is a rich debate regarding the metaphysical primacy of the particular. Compare P.F. STRAWSON, INDIVIDUALS: AN ESSAY IN DESCRIPTIVE METAPHYSICS (1959) (arguing that the particular, rather than the concept, is the paradigm logical subject), and E.J. Lowe. The Metaphysics of Abstract Objects, 92 J. PHIL. 509, 522-23 (1995) (arguing for a metaphysical understanding of objects), with ROBERT B. BRANDOM, ARTICULATING REASONS: AN INTRODUCTION TO INFERENTIALISM 123-55 (2000) (arguing in favor of privileging inference (use of concepts) over reference (use of singular terms); objects, or singular terms, exist in light of logical linguistic conditional conventions of the form, "If $\mathrm{X}$ is a dog, then $X$ is a mammal"). Cf. JaCQues BarzUn, A STROll WITH WILliam James 58-65 (1983) (commending focus on the concrete and particular, rather than the abstract; "the things of worth are all concretes and singulars"). 
look elsewhere to influence how they are used. A system that treats things as creatures of public policy has innumerable options for defining and manipulating things. That flexibility may be welcome from the lawmaking perspective, but from the perspective of legitimacy and authority, it creates difficulties. Thingness matters, both to us and to law, because things are durable and stable. Having standards for thingness that are manipulable in the service of public policy is a short step from having no standards; and without standards, it is difficult to say that we have things at all-especially in a world where such a conclusion is flatly inconsistent with our everyday intuition. Policy-based thingness may be the most pliable but least authoritative approach that the law might choose.

In the middle lie what may be the most interesting regulatory choices-areas where thingness is constrained in one way or another, but where those constraints offer distinct regulatory advantages and drawbacks, and raise comparable questions about legitimacy. My point is not to argue that one model is better than any other, either in general or in a particular context. My point is simply that legal regulators have these choices to make, and that their choices have implications for legitimacy and authority. All too often, thingness is either taken for granted by law or becomes the object of regulation, without regulators being aware that this is what is happening.

This Article is organized around presentation and evaluation of the five methods of thing-making that I referred to above, which I characterize as thing-by-nature, thing-by-design, thing-by-contract, thing-by-practice, and thing-by-policy. Each one is manifest in contemporary legal practice. Each derives from one or more important philosophical, psychological, and/or economic analytic traditions-again, using each of those labels in a less than perfectly rigorous sense. I illustrate each framework with examples drawn primarily from copyright, patent, and trademark law, but the analysis links intellectual property concerns to antitrust concerns, to commercial law, and to tangible property, among other things. Each analytic framework is given its own Part below. The sequence is designed crudely to mirror the extent to which a thing may be a function of itself, of its creator, of individuals or firms closest to it, and/or of those that give it context. Part III deals with natures, Part IV with designers, Part V with contracts, Part VI with culture, and Part VII with welfare. Part II, which follows this Introduction, briefly reviews the character of the social, technical, and legal changes that warrant framing the examination as I have. 
There is an important set of questions that is subsidiary to "what makes a thing a thing?," including: Is this a thing? What kind of thing is it? Which thing-if there is more than one available-should we focus on, and how should the question be decided? When does "thingness" matter? When does physical thingness matter, and when does conceptual thingness matter? And do these differ? ${ }^{16}$ To an extent, each of them is considered below. Yet each of them is not truly new, and none of them is entirely distinct from the others. Each one involves challenges to age-old choices between trusting what we see rather than what we know, and between valuing what we construct rather than what we are given. Below, both illustrations and analysis bring out historical, thematic conflicts between art and nature, and between perception and cognition, that are bundled up in searches for legal things. This is not an argument about property as such, or about intellectual property, or about antitrust or commercial law. I have something to say about these and other specifics, but in combining arguments and examples from a host of nominally distinct doctrines and theories, I reach for a different, more general, and clearly more difficult point. I want to prompt a reexamination, at a fundamental level, of how law and society interact.

As the phenomenal world evolves, and as we change it, how we approach that world-our methods of studying and analyzing itshould evolve as well. I use the term "things" as an organizing principle, but I am conscious of its protean character. All of the connections among my doctrinal and theoretical examples may not yet be exposed; some of the connections I present below may prove mistaken. I am convinced, however, and describe in the next Part, that the times call for a novel view of the landscape. Ishmael, narrator of Melville's Moby-Dick, contemplated the headless carcass of a sperm whale, floating among the waves, and he considered that for years afterward, ships would avoid the spot of the dead whale for fear of breaking up on spurious "rocks": "There's your law of precedents; there's your utility of traditions; there's the story of your obstinate survival of old beliefs never bottomed on the earth, and now not even hovering in the air! There's orthodoxy!"17 To the importance of whales and things, metaphorical and otherwise, I now turn.

16 See supra note 10 and accompanying text.

17 Herman Melville, Moby-Dick, OR The Whale 309 (Northwestern Univ. Press 1988) (1851). I borrow the quotation from John T. Matteson, Grave Discussions: The Image of the Sepulchre in Webster, Emerson, and Melville, 74 THE NEW ENG. Q. 419, 440 (2001), a thoughtful discussion of representations of law in nineteenth century American literature. The cetacean metaphor is not so fanciful as all that. Moby-Dick is partly a narrative of epistemology. Should one accept the illusion (Ishmael's perspective) or pursue the truth (Ahab's)? I prefer Melville here only slightly to Borges, who reported on "a certain Chinese encyclopedia entitled 


\section{THE IMPORTANCE OF THINGS}

Things have always been special to us in law and culture, whether we have acknowledged it or not, because they have at least three important effects. One is retrospective. Things embody history and knowledge. One is prospective. Things communicate that history and knowledge to others and to future generations. The third is contemporary. The bridge between the retrospective and prospective influence of things lies in their authority, that is, in the behavioral and cognitive influence they exert over individuals and firms that buy, consume, and reuse things, and, importantly, the extent to which that influence may be challenged by (that is, mediated by) those individuals and firms. Things embody meaning. Felix Cohen resisted thingification precisely because, socially and legally, things are authoritative-they govern, exercising authority over our behavior by virtue of what they can, and cannot, be used for. Thingness thus has a symbolic and communicative function as well as a material function in any discipline or community in which particular tangible objects play roles. ${ }^{18}$ The relative permanence and stability of the thing helps to give it authority,

Celestial Emporium of Benevolent Knowledge" that recorded that

animals are divided into (a) those that belong to the Emperor, (b) embalmed ones, (c) those that are trained, (d) suckling pigs, (e) mermaids, (f) fabulous ones, (g) stray dogs, (h) those that are included in this classification, (i) those that tremble as if they were mad, (j) innumerable ones, (k) those drawn with a very fine camel's hair brush, (l) others, (m) those that have just broken a flower vase, (n) those that resemble flies from a distance.

JORGE LUIS BORGES, The Analytical Language of John Wilkins (1942), reprinted in OTHER INQUISITIONS: 1937-1952, at 101, 103 (Ruth L.C. Simms trans., 1964). Updating Melville, and prompted by Borges, Foucault wrote: "In the wonderment of this taxonomy, the thing we apprehend in one great leap, the thing that, by means of the fable, is demonstrated as the exotic charm of another system of thought, is the limitation of our own, the stark impossibility of thinking that." Michel FOUCAULT, THE ORDER OF THINGS: AN ARCHAEOLOGY OF THE HUMAN SCIENCES Xv (1970) (1966).

18 On the role of artifacts in mediating scientific communities, see Davis BAIRD, THING KNOWLEDGE: A PHILOSOPHY OF SCIENTIFIC INSTRUMENTS (2004); DIANA CRANE, INVISIBLE COLleges: Diffusion of KNOWLEdGe IN SCIENTIFIC COMMUNITIES (1972); DEREK J. DE SOLLA PRICE, SCIENCE SINCE BABYLON (1961). For discussions of the simultaneously oppressive and liberating possibilities of material culture in other contexts, see MIHALY CSIKSZENTMiHAlyi \& EugEne Rochberg-Halton, The MEANING OF THINGS: DOMESTIC SYMBOLS AND THE SELF (1981); DONALD MACKENZIE, KNOWING MaChINES: EsSAYS ON TeChNical Change (1996); Material Cultures: Why SOME THINGS MATtER (Daniel Miller ed., 1998); LANGDON WINNER, Do Artifacts Have Politics?, in THE Whale AND THE REACTOR: A SEARCH FOR LIMITS IN AN AGE OF High TECHNOLOGY 19 (1986); Arjun Appadurai, Introduction: Commodities and the Politics of Value, in THE SOCIAL LIFE OF THINGS: COMMODITIES IN Cultural PERSPECTIVE 3 (Arjun Appadurai ed., 1986); Margaret Jane Radin \& Madhavi Sunder, Introduction: The Subject and Object of Commodification, in RETHINKING COMMODIFICATION: CASES AND READINGS IN LAW AND CUlTuRE (Martha M. Ertman \& Joan C. Williams eds., 2005) [hereinafter RETHINKING COMMODIFICATION] (noting that asking how things are created is a way of asking how law constructs culture). 
mediated via the artifact itself, rather than through interpersonal communication or other institutions. ${ }^{19}$

The authoritative nature of things, like all authority, comes from somewhere. In an immediate, physical sense, that authority comes from materiality. Things exert a behavioral influence. Less directly, but no less importantly, things are authoritative because of their social roles. A thing is not a "thing" in a relevant sense unless the object is given a relatively stable, communicative existence. It is not enough that the object has material limitations. We must also refer to the object as the "thing" that it is or appears to be, and once we do so, we must act accordingly. That authority may arise organically, via practice. ${ }^{20}$ Not infrequently, though, that authority stems from legal recognition of thingness. Some would argue that the processing of practice by law is an iterative process that produces things. ${ }^{21}$ An object or

19 See AdRian Johns, The Nature of THE Book: PRINT AND KNOWLedge IN THE MAKING (1998). On how salient and stable objects enable collaborative activity, see Barbara Tversky \& Paul U. Lee, How Space Structures Language, in LECTURE NOTES IN COMPUTER SCIENCE; SPATIAL COGNITION, AN INTERDISCIPLINARY APPROACH TO REPRESENTING AND PROCESSING SPATIAL KNOWLEDGE 157, 163 (Christian Freska, et al. eds., 1998) (describing the role printing played by in the formation of scientific knowledge). The classic discussion of focal points as solutions to problems among group members is THOMAS C. SCHELLING, THE STRATEGY OF CONFLICT (1960).

20 See BRANDOM, supra note 15 , at 163-83 (analyzing one primary representational solution of ordinary language); see also ROBERT B. BRANDOM, MAKING IT EXPLICIT: REASONING, REPRESENTING, AND DISCURSIVE COMMITMENTS (1994) (discussing the relationship between meaning and use).

21 See Penner, supra note 4, at 807.

The beginning of wisdom here is to realize that there is not a world of "things" out there all ready to be appropriated as property. This was the spark of genius in Hohfeld's claim about property as a complex aggregate of legal relations. "Thing" here is a term of art which restricts the application of property to those items in the world which are contingently related to us, and this contingency will change given the surrounding circumstances, including our personal, cultural, and technological circumstances.

Id.; Schroeder, supra note 4, at $1285 \mathrm{n} .17$ ("We don't 'reify' intangibles, in the sense of treating that which is not 'naturally' a thing as a thing. Rather, the very concept of what is or is not a 'thing' is itself artificial-a matter of legal characterization or definition."); Sherwin, supra note 4 , at 1088 ("[T]he objects of property need not be physical things, they need only be sufficiently well-defined to retain their identity in a variety of settings. They must be legal things, the boundaries of which are not physical lines but legal rules expressed in a physical form."). This theory of things is conceptually related to Alan Hunt's constitutive theory of law. See ALAN HUNT, EXPLORATIONS IN LAW \& SOCIETY: TOWARD A CONSTITUTIVE THEORY OF LAW (1993) (arguing that law and society scholarship should investigate the extent that law constitutes social relationships). The constitutive theory is iterative, but maintains a conceptual distinction between law and its object that I suspect is disappearing, at least in part. The constitutive theme operates not only at these most conceptual of levels, see JAMES C. EDWARDS, THE AUTHORITY of Language: Heidegger, Wittgenstein, and the Threat of PHILOSOPhical. Nihilism (1990), but also at the most mundane. See GeOFFrey C. BowkER \& Susan Leigh Star, SORTING THINGS OUT: CLASSIFICATION AND ITS CONSEQUENCES (1999) (discussing the construction of classification systems); BRUNO LATOUR \& STEVE WOOLGAR, LABORATORY LIFE: THE CONSTRUCTION OF SCIENTIFIC FACTS 277 (1986) (describing laboratory practice); MARY POOVEY, HISTORY OF THE MODERN FACT: PROBLEMS AND KNOWLEDGE IN THE SOURCES OF 
concept is or is not a thing in this sense until the legal system says that it is. Legally, things do not simply spring forth by appropriation from the domain of the unowned and unclaimed. ${ }^{22}$ They arise via an iterative analytic process that produces their authenticity and legitimacy. ${ }^{23}$ Once we have determined that something is a thing, we must determine what sort of thing it is, that is, what kind of authority it has and the legitimacy of that authority.

This authoritative role extends to conceptual things as well as to physical things and, importantly, to those sorts of blended things that are of particularly modern legal concern. Trademarks, for example, are not things in an organic sense, but the organic production of meaning associated with a given symbol may give rise, legally, to the thing that we call a trademark. Even if the notion of trademark-asthing is not part of the conventional understanding of trademark law, Barton Beebe's semiotic analysis of trademarks confirms that the trend toward trademark-as-thing is specifically observable, and perhaps justifiable, in two classes of cases: (1) the "merchandising right" cases, in which the mark becomes a good in its own right, as in the case of marks of manufacturers of athletic apparel or professional sports teams; ${ }^{24}$ and (2) product design cases, in which the mark is indistinguishable from the tangible form of the product. ${ }^{25}$ In both con-

WEALTH AND SOCIETY (1998) (describing the evolution of numeric representations of wealth). The law struggles to keep up, but it has not succeeded. See, e.g., Feist Publ'ns, Inc. v. Rural Tel. Serv. Co., 499 U.S. 340, 350 (1991) (denying the possibility of copyright in facts on the ground that facts lack authorship).

${ }_{22}$ This is the classic but mistaken premise of property doctrine. See, e.g., Haslem v. Lockwood, 37 Conn. 500 (1871) (holding that a plaintiff can maintain a cause of action for trover against a defendant who appropriated a pile of manure that the plaintiff collected from droppings on the public street and left untended for a period of time).

${ }^{23}$ Law is ontologically subjective though epistemologically objective. JOHN R. SEARLE, THE CONSTRUCTION OF SOCIAL REALITY 8-13 (1995). A practical example (I resist the temptation to call it a real world example) is the copyrightability of things manufactured by players within the confines of virtual reality environments: this is thingness created by practice, validated by law. See F. Gregory Lastowka \& Dan Hunter, The Laws of the Virnual Worlds, 92 CAL. L. REV. 1 (2004). The non-legal antecedent of this point is BENJAMIN, supra note 13 (questioning the continuing vitality of value-based distinctions between original works of art and mechanically-produced reproductions).

${ }^{24}$ See Barton Beebe, The Semiotic Analysis of Trademark Law, 51 UCLA L. REV. 621, 657-61 (2004); see also Stacey L. Dogan \& Mark A. Lemley, The Merchandising Right: Fragile Theory or Fait Accompli?, 54 EMORY L.J. 461 (2005) (arguing that the so-called merchandising right is fragile as matters of both trademark doctrine and policy); Jessica Litman, Breakfast with Batman: The Public Interest in the Advertising Age, 108 YALE L.J. 1717, 1728-29 (1999) (criticizing this trend).

${ }_{25}$ See TrafFix Devices, Inc. v. Mktg. Displays, Inc., 532 U.S. 23 (2001) (holding that patentability of device in which plaintiff claimed a trademark interest was strong evidence of its functionality); Beebe, supra note 24, at 661-67. 
texts, the mark-as-thing serves as its own authority, validated by a legal regime that permits it to do so. ${ }^{26}$

The weight of the authority of things varies, like the weight of legal authority. The traditional character of the authority of a thing depends largely on the ex post regulatory regime to which the thing belongs. A thing that is part of the regime of trade secret law is less authoritative than a thing that is part of the patent regime, because the trade secret regime permits most attempts to "reverse engineer" the trade secret-take apart the device to learn how it works-and the patent regime does not. A book, which can be resold by a lawful purchaser, is less authoritative than a computer program, the use of which is frequently limited to the authorized "licensee."

If and when law and design merge in physical and conceptual senses, following metaphoric and in some cases literal blending that I describe below, what happens to this authority? Either the authority of law may be reduced, or the authority of things may increase. ${ }^{27}$ Technical controls embedded in the design of physical artifacts, blessed by courts under a variety of legal regimes, facilitate the creation of "things" that regulate behavior in the sense that they constrain how people use or experience those things, but are not subject to regulatory review equivalent to the review accorded legal regulation. For example, not only may a traditional "book" be lawfully resold without the consent of the copyright owner, but its intellectual content likewise may be reused, under the fair use doctrine or under doctrines distinguishing idea from expression and similar from dissimilar copying. An electronic book that embeds technology-based copy and use controls need not be exposed to these vagaries of ex post copyright. ${ }^{28}$ The dividing line here is not sharp, but it is clear that in the latter

26 See also Kenneth Vandevelde, The New Property of the Nineteenth Century: The Development of the Modern Concept of Property, 29 BUFF. L. REv. 325, 328-29, $341-48$ (1980) (noting dephysicalization of American property law during the nineteenth century, and the rise of "conceptual imperialism" and physicalist fictions); Robert G. Bone, Hunting Goodwill: $A$ History of the Concept of Goodwill in Trademark Law 86 B.U. L. REv. (forthcoming 2006) (on file with author) (describing pre-Realist view of goodwill as a natural, property-like "thing" recognized by trademark law and arguing that goodwill-as-thing gets in the way of proper policy goals of trademark law, which is consumer protection).

${ }^{27}$ Emily Sherwin notes the costs of what she calls three-dimensional things, that is, fully or partly specified things, in contrast to two-dimensional, or unspecified, things. The specifications may be arbitrary, may interfere with or constrain government regulation (such as redistributive goals), and are resistant to change. See Sherwin, supra note 4, at 1099.

28 The phenomenon has been characterized by some in terms of enabling and disabling technologies. Analog technologies enable. By their nature, they allow for disassembly and tinkering for access to the knowledge they embody. Digital technologies disable, because they can be easily configured to limit that access. See Bob Colwell, The Coolest Thing on Earth, 10 COMPUTER, Nov. 2002, at 74 (reminiscing about the virtues of the Heathkit "build your own" computer kit). 
class of cases, law and design merge. Property interests are now conventionally understood as forms of governance. ${ }^{29}$ When governance and artifact are combined, the thing itself regulates. We move from ex post regulation via law to ex ante regulation via thing. Recent claims alleging that peer-to-peer networks wrongfully allow individuals to share or swap songs may be recast as arguments about the thingness of the musical work and of the recording that embodies that work, or about the thingness of the record album, distinct from the recording of the particular song. ${ }^{30}$ There is the landscape of claims made under the anticircumvention provisions of the Digital Millennium Copyright Act, in which producers of entertainment products ${ }^{31}$ and of "ordinary" objects $^{32}$ argue that the "things" they produce are inherently technologically bound. A DVD can be played only on a CSS-enabled "DVD" player or disk drive. A computer printer can be used only with a designated ink cartridge. A garage door opener can be used only with a designated remote control. Consumers argue that unfairly restrictive controls have been superimposed on preexisting objects. Producers reply that the things themselves have been redesigned.

The basic question in these cases is the extent to which arguments over the thingness of the object should be divorced from how the object is used or experienced. The question extends beyond computer technology. Bioengineered seeds tolerate engineered pesticides but not others (are these different seeds, or the same seeds coupled with anticompetitive restraints?). ${ }^{33}$ "Disposable" cameras are labeled "single-use only" ${ }^{\text {"34 }}$ to prevent the development of aftermarkets in camera

29 See Yochai Benkler, Siren Songs and Amish Children: Autonomy, Information, and Law, 76 N.Y.U. L. REV. 23 (2001) (describing the role of private property rights in regulating the information economy); Morris R. Cohen, Property and Sovereignty, 13 CORNELL L.Q. 8 (1927); Henry E. Smith, Semicommon Property Rights and Scattering in the Open Fields, $29 \mathrm{~J}$. LEGAL STUD. 131 (2000).

30 See Metro-Goldwyn-Mayer Studios, Inc. v. Grokster Ltd., 125 S. Ct. 2764 (2005) (reversing summary judgment granted in favor of developer of file sharing software for copyright infringement); In re Aimster Copyright Litig., 334 F.3d 643, 648 (7th Cir. 2003) (affirming injunction against operator of file sharing system); Shubha Ghosh, Turning Gray into Green: Some Comments on Napster, 23 HASTINGS COMM. \& ENT. L.J. 563, 564-65 (2001) (discussing Napster's role as a new distribution network for songs, allowing users to rebundle songs as a new product).

31 See Universal City Studios, Inc. v. Corley, 273 F.3d 429 (2d Cir. 2001) (affirming injunction against "trafficking" in technology enabling circumvention of CSS system for DVD playback).

32 See Lexmark Int'l, Inc. v. Static Control Components, Inc., 387 F.3d 522 (6th Cir. 2004) (rejecting claims by makers of computer printers); Chamberlain Group, Inc. v. Skylink Techs., Inc., 381 F.3d 1178 (Fed. Cir. 2004) (similarly rejecting claims by makers of garage door openers).

${ }_{33}$ See Monsanto Co. v. McFarling, 363 F.3d 1336 (Fed. Cir. 2004) (affirming judgment against farmer who saved and planted "Roundup Ready" seeds in violation of agreement with producer).

${ }_{34}$ See Jazz Photo Corp. v. Int'l Trade Comm'n, 264 F.3d 1094 (Fed. Cir. 2001) (rejecting 
bodies. Ink cartridges for computer printers include the warning, " $\mathrm{Li}$ censed For Single Use Only" to prevent the cartridges from being refilled by consumers or others. ${ }^{35}$ Can these "single-use" cameras and cartridges be remanufactured, that is, used twice?

That question plays unfairly with the words "can" and "use," but in each of these examples, there is an implicit or explicit claim being made that one ought not to be able to use or reuse these "things" in ways that violate their inherent "thingness"-whatever that is. ${ }^{36}$ The cases thus conceptually link problems that have been pointed out in isolation by a disparate group of scholars. Margaret Jane Radin and Julie Cohen each have discussed the linkage of machine-based and contract-based regulation of information. ${ }^{37}$ Glen Robinson has suggested that servitudes that forbid unauthorized use or disposition of chattels should ordinarily be enforceable, basing his argument largely on the law of computer software licensing. ${ }^{38}$ Annelise Riles has championed a call for humanistic legal scholarship to expose the workings of physical and conceptual "black boxes" in law, which she calls "the technicalities of law"-devices that work because of the knowledge that is built into them, rather than because of the knowledge that must be applied to them. ${ }^{39}$

patent infringement claims by manufacturer of "single-use" cameras against importer of remanufactured cameras).

${ }^{33}$ See Hewlett-Packard Co. v. Repeat-O-Type Stencil Mfg. Corp., 123 F.3d 1445, 145354 (Fed. Cir. 1997) (rejecting patent infringement claims against remanufacturer of ink cartridge, but suggesting in dicta that sale with a "restriction having contractual significance" might change the result); $c f$. Arizona Cartridge Remanufacturers Ass'n v. Lexmark Int'l, Inc., 421 F.3d 981, 986-88 (9th Cir. 2005) (finding that patent law permits printer cartridge manufacturer to sell cartridges subject to reuse restrictions, where restrictions were printed on packaging and customers assented by opening packages).

${ }^{36}$ Randal Picker characterizes a related problem as "the extent to which we are willing to reengineer these scope-of-permission goods [multiple variants of goods defined by access restrictions and/or added and disabled features] - to re-scope them-to enable entry." Randal C. Picker, Unbundling Scope of Permission Goods: When Should We Invest in Reducing Entry Barriers?, 72 U. CHI. L. REV. 189, 189-90 (2005). Anupam Chander argues that focusing on thingness opens a discussion regarding distributional issues. See Anupam Chander, The New, New Property, 81 TEX. L. REv. 715, 720-21 (2004). In the case of digital goods, Dan Burk notes the equivalence of designed things, shrink-wrap limitations on the use of things, and technological controls embedded in software. See Dan L. Burk, Legal and Technical Standards in Digital Rights Management Technology, 74 FORDHAM L. Rev. 537, 546-47 (2005).

${ }^{37}$ See Julie E. Cohen, Overcoming Property: Does Copyright Trump Privacy?, 2002 U. ILL. J.L. TECH. \& POL'Y 375; Margaret Jane Radin, Online Standardization and the Integration of Text and Machine, 70 FORDHAM L. REV. 1125 (2002); cf. Margaret Jane Radin, Regime Change in Intellectual Property: Superseding the Law of the State with the "Law" of the Firm, 1 U. OTTAWA L. \& TECH. J. 173, 187 (2003-2004) [hereinafter Radin, Regime Change] (discussing the implications of regulation by machine rather than by contract).

38 See Glen O. Robinson, Personal Property Servitudes, 71 U. CHI. L. REv. 1449 (2004).

39 Annelise Riles, A New Agenda for the Cultural Study of Law: Taking on the Technicalities, 53 BUFF. L. REV. 973, 975-76 (2005); see also BAIRD, supra note 18, at 162-65 
The changes implicit in these arguments are not merely (or even primarily) shifts from the tangible to the intangible-and back again -wrought by technology. The conceptual and physical evolution is both broader and more subtle. In an earlier era, and focusing on the legal objects of constitutional takings doctrine, Radin characterized the issue as "conceptual severance," that is, the ability of courts to narrow the scope of a property interest in order to heighten the severity of a government regulation. ${ }^{40}$ Today, however, the analytic arrow may point instead to aggregation, rather than severance, and it may point to physical changes as well as to conceptual ones. In each instance, it is not perfectly clear whether the regulatory referent has changed (so that the proper regulatory regime should shift), or whether the referent has not changed but the context of the regulation has (so that the regime should remain the same, but the manner in which the rule is applied should change). In some instances, one changes or the other does. In many instances, it may be both. To the extent that legal institutions take the thing as given and consider how to regulate it, they miss a significant opportunity to regulate via the construction and evolution of the thing itself. They also miss the ability to constrain improper regulation by nonlegal institutions involved with creating and changing thingness. There are, I think, at least five

(describing "black-boxing" as the movement of knowledge from outside the machine (you have to know how to use the machine) to inside it (you can use the machine anyway, without that knowledge, meaning that knowledge becomes tangible and portable across space and discipline)); BRUNo LATOUR, PANDORA'S HOPE: ESSAYS ON THE REALITY OF SCIENCE STUDIES 304 (1999) [hereinafter LATOUR, PANDORA'S HOPE] (describing how the evolution of science and technology brings opacity, that is, complexity that is made invisible by its own success); BRUNO LATOUR, SCIENCE IN ACTION: How TO FOLLOW SCIENTISTS AND ENGINEERS Through SOCIETY 2-3 (1987) (describing the use of black boxes); Langdon Winner, Upon Opening the Black Box and Finding It Empty: Social Constructivism and the Philosophy of Technology, 18 SCI., TECH., \& HUM. VALUES 362 (1993) (arguing that black boxes are expressions of the interactions of social networks and institutions).

40 Margaret J. Radin, The Liberal Conception of Property: Cross Currents in the Jurisprudence of Takings, 88 COLUM. L. REV. 1667, 1677 (1988). Thomas Merrill argues, instead, that takings cases are characterized by limits of a sort. See Thomas W. Merrill, The Landscape of Constitutional Property, 86 VA. L. REV. 885 (2000) (characterizing takings and due process cases according to "patterning" approaches to what constitutes a constitutional property interest in ways that limit opportunities for conceptual severance). Copyright law reflects similar efforts to define the copyrighted work either extremely narrowly or extremely broadly, to suit the purposes of the plaintiff and the court. Compare Castle Rock Entm't, Inc. v. Carol Publ'g Group, Inc., 150 F.3d 132, 138 (2d Cir. 1998) (locating copyright in the entire television series "Seinfeld"), and Metro-Goldwyn-Mayer, Inc. v. Am. Honda Motor Co., 900 F. Supp. 1287, 1293 (C.D. Cal. 1995) (locating copyright in the James Bond character "as expressed and delineated in Plaintiffs' sixteen films"), with Bridgeport Music, Inc. v. Dimension Films, 383 F.3d 390 (6th Cir. 2004) (protecting a recording of an arpeggiated chord, three notes, struck closely together, as a copyrighted work). 
sorts of transformations appearing in the world around us, with important implications for the law.

The first is clearly and purely technological. To borrow a term from Herbert Simon, both computer technology and biotechnology have increased our practical awareness of the "decomposability" and dynamism of things, ${ }^{41}$ particularly (but not only) tangible things, and our ability to use that decomposability and dynamism for an extraordinary range of ends. ${ }^{42}$ Complex systems are known to be often "decomposable" into simpler, distinct subsystems that are more comprehensible. Features can be added. Features can be removed. Is the feature a thing? Is the reconfigured object a thing? Moore $v$. Regents of the University of California, ${ }^{43}$ a property rights contest between a patient whose spleen was surgically removed and physicians who profited from patents based in part on the patient's tissues, is an early example of how this sort of "decomposability" creates problems for the law. Is the spleen a cognizable thing or not? The court did not decide the case on this basis, and it consciously

41 HeRBert A. SIMON, The Architecture of Complexity: Hierarchic Systems, in THE SCIENCES OF THE ARTIFICIAL 183, 197-201 (3d ed. 1996). In Simon's thinking, a decomposable system is a complex system that can be effectively described as a set of subsystems, where the interaction within subsystems is independent of one another. "Near decomposable" systems involve subsystems whose interactions are weak, but are not negligible. Both concepts are introduced to illustrate how the hierarchies implicit in complex systems can be broken down so that the systems themselves can be understood. "The fact then that many complex systems have a nearly decomposable, hierarchic structure is a major facilitating factor enabling us to understand, describe, and even 'see' such systems and their parts." Id. at 207. Any computer network, program, protocol, dataset, or combination thereof can be reduced from its most abstract, human-readable interpretation to its most elemental binary interpretation. That is a central feature of modern computing. Digital "information" can be sliced almost endlessly into "bytes" and "bits," for processing purposes, and into "packets," for Internet transmission purposes. Bits, bytes, and packets can be disassembled and reassembled; objects and files can be broken down and rebuilt at almost any scale. In digital form, a book literally and simply may be a collection of individual words. The neologism "Napsterization," after the infamous Napster file sharing system, is sometimes applied to the widespread, uncontrolled disassembling and reassembling of digital things.

42 Bill Brown speculates that concern with things blossomed in cultural studies in the 1990s just as it did in the 1920s for reasons related to technology-based changes in the proximity of people to objects. In the 1920 s, it was film; in the 1990 s, it was computers. Distance, in both cases, approximates value. See Brown, supra note 1, at 16 . It would be impossible to catalog all of the types of decomposability that we are now capable of. One particularly interesting example is the AURA technology developed at Microsoft Research, by which consumers could use portable handheld computers, combined with bar code scanners, to create a usermaintained database of information keyed to Uniform Product Codes (UPCs). See Marc A Smith, et al., Object AURAs: A Mobile Retail and Product Annotation System, 2004 Proc. 5TH ACM CONF. ON EleCtRONIC COM. 240 (2004). (The author Bruce Sterling refers to a similar, speculative combination of RFID technology and consumer control over object metadata as an "Internet of Things." Bruce Sterling, Risky Business, WIRED, Aug. 2005, at 74.) What "is" the product specified by the UPC? The information given in the manufacturer-compiled database? Or the information compiled by consumers? Both?

43793 P.2d 479 (Cal. 1990). 
avoided the temptation to resolve the case in the patient's favor on the basis of his property interest in the spleen. ${ }^{44}$ But as James Boyle argued, the case really does revolve around the thingness of the spleen. ${ }^{45}$ Confrontations between law and dynamic thingness are unavoidable.

Going a step further, we now increasingly possess the power technically to manipulate those subsystems not only to embed ordinary design choices into our things but consciously to embed very specific policy choices as well. Examples include protean systems of "Digital Rights Management" of digitized copyrighted and other works of information, such as those built into DVD players, computer printers, and garage door openers, ${ }^{46}$ as well as seeds designed for maximum production when used with compatible, engineered pesticides. ${ }^{47}$ In principle, "decomposability" now allows us not only to remove the spleen but also to engineer the removal so that the patient can monitor subsequent disposal or reuse of the tissue.

A second development is the spillover of this kind of lexicoarchitectural regulation of human conduct $^{48}$ to a broadening array of "ordinary" or "everyday" things, both physical and conceptual. We have the computer printer that requires an ink cartridge produced by the same manufacturer and the garage door opener designed to function only with the original manufacturer's remote control. There is the experimental automobile with a "hood" that can be opened only by an authorized service representative of the car's manufacturer. ${ }^{49}$

44 Id. at 490.

45 See James Boyle, Shamans, Software \& SpleEns: Law and the Construction OF THE INFORMATION SOCIETY 102-07 (1996).

46 See Susan P. Crawford, The Biology of the Broadcast Flag, 25 HASTINGS COMM. \& ENT. L.J. 603, 647-51 (2003) (describing the code/law "petri dish" that supports innovation in digital networks).

47 Not only have researchers produced "Roundup Ready" seeds that are specifically resistant to "Roundup" pesticides, but they have also made progress toward production of selfpolicing seeds that produce a sterile crop. V-GURTS (varietal or variety-level GURTS, or Genetic Use Restriction Technologies), commonly known as Terminator seeds, are genetic restriction technologies that restrict or control the reproductive capacity of plants, producing sterile seeds. The seeds were controversial when their commercial introduction was threatened, and their marketing has been limited, at least so far. See Keith Aoki, Neocolonialism, AntiCommons Property, and Biopiracy in the (Not-So-Brave) New World Order of Intemational Intellectual Property Protection, 6 IND. J. GLOBAL LEGAL STUD. 11, 54 (1998). "Terminator" technology physically instantiates comparable limitations on saved seed imposed on farmers via "bag-tag" licenses printed on seed packaging. For a discussion of judicial treatment of such "one-time-use" licenses, see infra note 250 and accompanying text.

48 See Lawrence Lessig, The Zones of Cyberspace, 48 STAN. L. REV. 1403 (1996); Joel R. Reidenberg, Lex Informatica: The Formulation of Information Policy Rules Through Technology, 76 TEX. L. REV. 553 (1997). James Gibson has christened this "technolegical" regulation, to note how thingness can complement law, as well as substitute for it. James Gibson, ReReifying Data, 80 NOTRE DAME L. REV. 163, 167-68 (2004).

49 See Jorn Madslien, Girl Power Softens Volvo's Edges, BBC NEws, Mar. 3, 2004, 
The components of an automobile can now be interlinked via computer microcode, essentially turning the automobile into a hardware platform for an automotive operating system. ${ }^{50}$ This benefits the consumer who wants to design her own automobile by specifying interoperable "modules" (brakes, suspension, and transmission, for example) designed to run on the car's operating system. It also benefits the manufacturer that wants to protect aftermarkets for parts and service, by controlling the design of the operating system and controlling access to it. ${ }^{51}$ Consumers may have to fight for the legal right to repair their own vehicles. ${ }^{52}$ The phenomenon of regulation-by-artifact is hardly new. An entire discipline-Science and Technology Studies (STS)—has grown up around examining the social consequences of technology. What appears to be changing is the degree to which technology permits social consequences, originally theorized to be the consequence of engineering decisions, ${ }^{53}$ to be part of the design process itself.

http://news.bbc.co.uk/go/em/fr/-/2/hi/business/3528757.stm. The design is ostensibly aimed at women, who are stereotypically disinclined to bother with their own car repairs. So as not to leave a one-sided impression of how the world of things is changing, consider a parallel development in the automotive universe: Ford (the parent of Volvo, as it happens) is demonstrating a concept vehicle that incorporates a Wi-Fi antenna, so that in effect, the car becomes an Internetenabled device or, more precisely, a node on a peer-to-peer file sharing system. Drivers and passengers could upload and download digital files and store them on a memory device built into the car. See Mike Wendland, SUV's Wi-Fi System Lets Drivers Leave CDs at Home, DETROIT FREE PRESS, June 24, 2004, http://www.freep.com/money/tech/mwend24_ 20040624.htm.

so See Norman Mayersohn, Beyond the Programmable Car, Automotive INDUS., Aug. 1999, at 40; Manufacturers Aim for Change in Electronics, AUTOMOTIVE INDUS., Apr. 6, 2001, at 5. Automotive subsystems have been controlled by computerized Electronic Control Units, or ECUs, for years. The contemporary shift involves a reduction in the number of ECUs (thus standardizing the control protocols) and a simultaneous expansion in the number of systems controlled by each one.

${ }^{51}$ Cf. Davidson \& Assocs. v. Jung, 422 F.3d 630 (8th Cir. 2005) (finding that the Digital Millennium Copyright Act (DMCA) prohibits reverse engineering of software platform for multiplayer video game in order to construct more stable equivalent); Storage Tech. Corp. v. Custom Hardware Eng'g \& Consulting, Inc., No. Civ.A. 02-12102RWZ, 2004 WL 1497688 (D. Mass. July 2, 2004) (barring technology owner from repairing device manufactured by plaintiff because doing so would involve "circumvention" of software owned by plaintiff), vacated, 421 F.3d 1307 (Fed. Cir. 2005). Interestingly, while the Federal Circuit rejected Storage Technology Corp.'s effort to limit third-party repairs to its computers, the court relied heavily on the fact that the software license delivered with the computers was drafted so that it was "tied to the piece of equipment on which the software resides. Thus, the authorized use is tied to a particular machine, rather than a particular person." Storage Tech. Corp. v. Custom Hardware Eng'g \& Consulting, Inc., 421 F.3d 1307, 1317 (Fed. Cir. 2005).

52 That precise principle has been raised in the proposed Motor Vehicle Owner's Right to Repair Act. See H.R. 2735, 108th Cong. (2003); S. 2138, 108th Cong. (2004).

53 See, e.g., JACQUes Ellul, THE TeChNOlogiCal SOCIETY (John Wilkinson trans., 1964) (1954); LATOUR, supra note 9; LeWIS MUMFORD, TECHNICS AND CIVILIZATION (1934); Langdon Winner, Do Artifacts Have Politics?, 109 DaEDALUS, Winter 1980, at 121. The notion of control-by-design dates at least to Jeremy Bentham's proposal for a panoptic prison. JEREMY 
Third is the blurring of distinctions between physical thingness and legally significant conceptual categories that include assent, property, antitrust, copyright, and patent, among others. Antitrust law looks to the domination of markets. In some markets, control of the thing is tantamount to control of the market. A court that defers to the design of the thing yields application of antitrust principles to the authority of the designer. In the copyright context, Julie Cohen has observed and objected to this sort of deference:

Precisely because copyright does not subsist in things, the things in which copies of works are embodied take on neariconic significance. Rights in the work and rights in the thing merge to constitute a sort of $\ddot{u} b e r$-copyright, a property right delineated as absolute sovereignty over the disposition and use of both work attributes and thing attributes. . . Rights in the work and rights in the thing become conflated, and strict controls are imposed upon access to and use of the thing to guard against perceived vulnerability of rights in the work. ${ }^{54}$

A manufacturer might design a device that automatically decays after a single use. Under nearly all circumstances, barring health or safety concerns, the law would defer to that choice, and in the event the device were the subject of a patent, the law might even bar the user from reconstructing the object, that is, from making it anew. ${ }^{55} \mathrm{~A}$ manufacturer might instead design a nondecaying, multiple-use thing labeled "single-use only." The manufacturer's anticompetitive motivation is likely the same, but using a label rather than a design may be less wasteful and may appear to intrude less on consumer autonomy. ${ }^{56}$ On the one hand, but for precisely that reason, it seems foolish to evaluate the latter choice under an "assent" framework rather than

Bentham, The PANopticon Writings (Miran Bozovic ed. Verso 1995) (1791).

${ }^{34}$ Cohen, supra note 37 , at 379.

ss See infra notes 114-19 and accompanying text for a discussion of the "right to repair" rule in patent law. For a comparative evaluation of technological and contractual "product degradation," see Randal C. Picker, Copyright and the DMCA: Market Locks and Technological Contracts, in ANTITRUST, PATENTS \& COPYRIGHT: EU AND US PERSPECTIVES (Francois Leveque \& Howard Shelanski eds., 2005).

56 See Robinson, supra note 38 , at $1467-68$ (making precisely this argument regarding servitudes on chattels). The conclusion here depends on the prevailing conception of personal autonomy. On the one hand, and as the text assumes, a consumer who is aware of a restrictive notice may choose to disobey the restriction; a consumer confronted with a restrictive design may not be aware of the design constraint, though there is the option not to use the item at all. On the other hand, the consumer may reflexively obey the notice but may not be aware of the sense in which the design constrains choice. In the second construction, the design restriction is superior to the restrictive notice in preserving personal autonomy. 
under property or antitrust or patent law principles. On the other hand, a court that endorses the label-and the trend in the cases is to do $\mathrm{so}^{57}$-enables the manufacturer successfully to collapse a series of traditional, distinct legal regimes into one, which is the thing itself.

The fourth shift is the assimilation to tangible things of legal forms developed for intangible things. The central illustration here is the phenomenon of licensing, which is migrating up a semantic ladder from the purely conceptual to the purely physical. ${ }^{58} \mathrm{~A}$ copyright or a patent can be licensed. Under current practice, a computer program (a semiphysical thing that depends on copyright and patent law for legal protection) can be licensed. It may shortly be the case that "ordinary" tangible objects, with no particular connection to underlying intellectual property interests, can likewise be licensed. There is the HewlettPackard printer cartridge, labeled so that it is not "licensed" for more than one use. ${ }^{59}$ There is a woodworking jig sold under a "shrinkwrap" license that is worth quoting in full:

The purpose of the TemplateMaster ${ }^{\text {TM }}$ is to clone itself. Therefore we are verifying your honesty that only you will use the tool and you will not be passing it around to others to use for free. It is exactly the same as the "shrink-wrap" agreement that comes with almost all computer software. Please help us fight "tool piracy.",60

It is far from certain that licenses of tangible objects would be enforceable under current law, even if a buyer were to "assent" to them. What is noteworthy in the examples is the collapse of a distinction. If computer software can be licensed, can anything be licensed? The doctrinal answer likely would be that copyright law makes software different. But the software industry has not rested its case on copyright, nor on the law of assent. In Adobe Systems, Inc. v. One Stop Micro ${ }^{61}$ the software developer Adobe Systems argued that its soft-

57 What I call a trend is discernible by combining cases from several different sources, including enforcement of shrink-wrap and click-wrap agreements, which are mere notices in all but pure form, and trespass to chattels cases. See, e.g., Monsanto Co. v. McFarling, 363 F.3d 1336 (Fed. Cir. 2004); Bowers v. Baystate Techs., Inc., 320 F.3d 1317 (Fed. Cir. 2003); Register.com, Inc. v. Verio, Inc., 356 F.3d 393 (2d Cir. 2004); eBay, Inc. v. Bidder's Edge, Inc., 100 F. Supp. 2d 1058 (N.D. Cal. 2000).

${ }^{38} C f$. Hunter, supra note 10 (decrying the uncritical application of real property legal theory and metaphor to intangible property issues); Lemley, supra note 10 (same).

59 The label partly responds to a patent law concern, see supra note 35 and accompanying text, but nothing in or on the cartridge links the "license" to that concern. Neither the cartridge nor its packaging is marked with a patent number.

${ }^{60} \mathrm{FAQ}$ [for Stots Corporation, manufacturer of woodworking jigs], http://www.stots. com/faqs.htm (last visited Oct. 3, 2005).

61 84 F. Supp. 2d 1086 (N.D. Cal. 2000). 
ware license was enforceable against a defendant who unbundled and resold Adobe's programs without Adobe's permission. This was so, not because the defendant had agreed to it (in fact, there was no assent), and not because the inherent reproducibility of software requires more precise producer control over its use, but because it was the very nature of computer software that it be licensed..$^{62}$ The license was built into the nature of the thing.

Fifth, and last, is the widely discussed trend to reify the physical thing-like characteristics of concepts and intangible "information" phenomena, such as computer programs, computer networks, and information-oriented inventions and other intellectual creations. Computer networks are "places" or "things," and unauthorized access to them will support claims for trespass of a sort that echo claims for trespass to real property. ${ }^{63}$ Copyrighted music and satellite and cable television signals can be "stolen" or "pirated."64 A business method is no less an invention than an industrial machine, and it is no less patentable. ${ }^{65}$ The Realist scholar Felix Cohen warned of the thingification of concepts that enables courts to avoid considering the policy consequences of their decisions, ${ }^{66}$ a concern that applies to natural and artificial objects as well as to the purely social. It remains to be seen whether thingification is as wholly bad as Cohen intimated, but the phenomenon is with us still.

It is not the case, I suspect, that all five of these changes have happened, or even that they all are happening to the same degree. They are related tendencies in law and culture that offer entrées to a different way of looking at problems clustered familiarly around the notion of relations between people. Where the Legal Realists asked, when and how should the law regulate one person in her dealings with an-

62 See id. at 1090-92.

63 See Register.com, Inc. v. Verio, Inc., 356 F.3d 393 (2d Cir. 2004); eBay, Inc. v. Bidder's Edge, Inc., 100 F. Supp. 2d 1058 (N.D. Cal. 2000). David McGowan insists that these courts did not really see Internet facilities as physical places; at most, courts were using placeoriented language metaphorically, rather than as bases for their decisions. See David McGowan, The Trespass Trouble and the Metaphor Muddle, 1 J.L. ECON. \& POL'Y (2005). The blending of the metaphorical and the physical is precisely the point. The problem is not that courts cannot tell the difference. They clearly can. But they do not see a compelling reason to do so.

${ }^{64}$ See McRoberts Software, Inc. v. Media 100, Inc., 329 F.3d 557, 568 (7th Cir. 2003); 321 Studios v. Metro Goldwyn Mayer Studios, Inc., 307 F. Supp. 2d 1085, 1103 (N.D. Cal. 2004).

${ }^{65}$ See State St. Bank \& Trust Co. v. Signature Fin. Group, Inc., 149 F.3d 1368 (Fed. Cir. 1998)

${ }^{66}$ See Felix S. Cohen, Transcendental Nonsense and the Functional Approach, 35 COLUM. L. REV. 809, 814-17 (1935) (declaring that it is wrong for courts to declare the existence of a "pre-existent Something" as the basis for assigning and enforcing property rights). Modern concern over "commodification" of information captures a related but narrower concern. See generally Radin \& Sunder, supra note 18. 
other?, the evolving blending of relations and things suggests that we should again ask, when and how should the law regulate what can and cannot be done with a thing? Together these developments might be characterized metaphorically as a substantial blending of software (the subjective, intangible, or conceptual) and hardware (the objective, the physical, or the concrete). Treat the law as a computer. A "classical" view of law applied software (that is, law) ${ }^{67}$ to hardware (that is, physical reality). Just as a contemporary technologist understands that there is no meaningful conceptual distinction between computer hardware and computer software, ${ }^{68}$ a contemporary understanding of law requires accepting metaphorically an equivalent disappearance of boundaries. There once was, à la Dr. Seuss, a Thing One and Thing Two. Today we are witnesses to the fluidity of thingness, the increasing lack of givenness of both material and conceptual things. ${ }^{69}$

67 Cf. A. Michael Froomkin, Article 2B as Legal Software for Electronic ContractingOperating System or Trojan Horse?, 13 BERKELEY TECH. L.J. 1023 (1998) (characterizing proposed Article $2 \mathrm{~B}$ of the Uniform Commercial Code as a bug-ridden operating system for a computer). The same point might be made using a biotechnology metaphor. Jim Chen notes that a seed is simultaneously a chattel and a container for a genome, and that genome itself is both a cumulative record of the organism's evolutionary history and an instruction set for building and operating another chattel. See Jim Chen, Webs of Life: Biodiversity Conservation as a Species of Information Policy, 89 IowA L. Rev. 495, 565 (2004).

68 Theory and technological reality are closing in on one another. The technology known as Field Programmable Gate Arrays (FPGAs), sometimes known as "systems on a chip," can be used in computer chips to configure hardware resources to implement functionality, as if those resources were software. Xilinx (http://www.xilinx.com) and Altera (http://www.altera.com) are industry leaders. See Bill Roberts, Software or Silicon?, ElECTRONIC BUS., Oct. 2003, at 17; Altera Corp. v. Clear Logic, Inc., 424 F.3d 1079 (9th Cir. 2005) (affirming legal right of Altera to tie chip design services to sale of designed integrated circuits).

69 Thingness matters not only at the creation of things, but also at their destruction, see Joseph L. SaX, Playing Darts with a Rembrandt: Public and Private Rights $\mathbb{N}$ CULTURAL TREASURES (1999) (reviewing a variety of conflicts over privatization of culturally significant artifacts); Lior J. Strahilevitz, The Right To Destroy, 114 YALE L.J. 781 (2005), and during their existence. See Randal C. Picker, Rewinding Sony: The Evolving Product, Phoning Home and the Duty of Ongoing Design, 55 CASE W. RES. L. REV. 749 (2005). 
This is more than mere manipulation of language ${ }^{70}$ though there is undoubtedly authority in the language that we (and courts) use. The relationship between an object and its description is subject to redefinition in ways that significantly affect how the object exercises authority in law. But that redefinition is not endlessly malleable. It is limited by social structures and social conditions. How courts attach language to things has real-world influences and real-world consequences, and it is possible to understand the range in which courts work. The real world payoff, in other words, is the following. When courts and legislatures answer the questions, "Is this a thing?" and "What kind of thing is it?," they are simultaneously choosing legal and social practices to attach to that thing, both descriptively and prescriptively. Others have noted that the world of regulatory technology raises questions about the who of our material environment. ${ }^{71} \mathrm{My}$ concern is expressly the how. It is not enough to know the source of things. We need to understand the processes of things. Taking apart the construction of legal things-showing links between the technical and the social-can expose the true complexity of the regulatory pal-

${ }^{70} \mathrm{I}$ invoke semantics at this point only to counter the anticipated objection that my argument can be reduced to the point that language, including the language of things, generates and reinforces power-based relationships. The point does not go far enough. If the goal of analyzing things is to expose a power dynamic at work in their construction, it is not enough to complain about terminology. See Edward L. Rubin, Computer Languages as Networks and Power Structures: Governing the Development of XML, 53 SMU L. REv. 1447, 1465-67 (2000) ("When a new language is created, ... its creators are able to exercise political effects of a more comprehensive nature by the design decisions that they make."). We need to understand the specifics of the processes that the law uses. A computer language is not merely a medium of communication. It is simultaneously an object, that is, a thing, which in this case is potentially copyrightable. See Trotter Hardy, The Copyrightability of New Works of Authorship: "XML Schemas" as an Example, 38 Hous. L. REV. 855 (2001). Rubin tums from the diagnosis of thing-as-regulators to a solution based on a direct connection between the design process and interpretation of design by users, omitting the role of legal institutions in taking the designer's work and making it legally meaningful.

I use the term "semantics" here in the nontechnical sense as "analysis of meaning." On the formal distinction between semantics (meaning as something that sentences have) and pragmatics (meaning as something that people do) in linguistics and in philosophy, see Kent Bach, The Semantics-Pragmatics Distinction: What it Is and Why It Matters, in 1 THE SEMANTICS/Pragmatics INTERFACE From DifFERENT POINTS OF VIEW 65-84 (Ken Turner ed., 1999). Wittgenstein's distinction between semantics (the meaning of language) and pragmatics (the use of language) is discussed infra at notes 276-79 and accompanying text, in connection with Wittgenstein's "family resemblances" perspective on the application of language to objects.

7 See LAWRENCE LeSSIG, CODE AND OTHER LAWS OF CYBerSPACE (1999); James Boyle, Foucault in Cyberspace: Surveillance, Sovereignty, and Hardwired Censors, 66 U. CIN. L. REV. 177 (1997); Cohen, supra note 37, at 379, 382-83 (arguing that the problem of thingness is a problem of power). See generally Margaret Jane Radin, Regulation by Contract, Regulation by Machine, 160 J. INST. THEORETICAL ECON. 142 (2004) (describing the effect of mass standardized contracts and digital rights management systems on the distribution of intellectual property rights); Radin, Regime Change, supra note 37 (describing "sovereignty" of work controlled by Digital Rights Management technology (DRM)). 
ette, allow us more clearly to appreciate the virtues and drawbacks of the different shades of that palette, and to promote or resist changes in how the palette is applied. ${ }^{72}$ The following Parts of this Article explore the character of the mechanisms that produce contemporary things.

\section{THING-BY-NATURE}

If the premise of the Article is explicitly pragmatic, ${ }^{73}$ then the bulk of the Article shows that courts and legislatures have largely failed to learn the pragmatist lesson. By taking legal institutions at their word, I intentionally set aside the argument that focusing on things themselves is error. ${ }^{74}$ This Part begins, then, with the reminder that a great deal of our "things" jurisprudence takes up thingness ontologically, or to put the matter more colloquially, relies on a crude essentialist or Aristotelian approach to thingness. Aristotle observed that objects in the natural world could be understood, described, and classified according to their properties, the most fundamental or foundational of which were their "essential" substances. The Aristotelian tradition is alive and well in both law and philosophy, notwithstanding various calls to avoid categorizing and analyzing the world based on the way things "really" are. Things are what they naturally are, and that means they are what their properties specify them to be.

I (and in the examples I review below, courts) bundle together some issues that philosophers have been careful to distinguish. What I have labeled an "Aristotelian" or "essentialist" approach is a rough synthesis of an intellectual tradition that began with Plato and Aristotle, continued through Augustine and Descartes, and culminated in Kant. ${ }^{75}$ That tradition seeks to draw important distinctions based on

72 See Boyle, supra note 71, at 205 (pointing out the Lochnerian sense of technology, like the free market, as "just the way things are" and thus relatively immune to analyses of its coercive implications and effects).

${ }^{73}$ See Michael Sullivan \& Daniel J. Solove, Can Pragmatism Be Radical? Richard Posner and Legal Pragmatism, 113 YALE L.J. 687, 692-714 (2003) (book review) (defending a "thicker" form of legal pragmatism).

${ }^{74}$ For example, Arjun Appadurai argues that "even though from a theoretical point of view human actors encode things with significance, from a methodological point of view, it is the things-in-motion that illuminate their human and social context." Appadurai, supra note 18, at 5; see also Radin \& Sunder, supra note 18 (arguing that things themselves are neither optimistic nor pessimistic; it depends upon how they are used).

75 Eighteenth century Kantian and early nineteenth century Hegelian traditions postulated the existence of "things" with reference to objects existing outside the self, and in which both object and thing were essentially static. Kant's unknowable but essential "thing in itself" (or "things considered in themselves") ("noumenon"), distinguished from its knowable "appearance" (or "things considered as they appear") ("phenomenon"), presupposed the existence of an "object," the target of perception and representation and dependent on space and time. See Immanuel Kant, CritiQue of PURE ReAson at B295-B315 (Paul Guyer \& Allen W. Wood 
the nature of reality, whether that consists of the "true" nature of reality (that is, the ontological question of what "kinds" of things exist) or of our thought about that reality. Philosophers have asked whether a thing exists at all, that is, whether we can know the existence of the thing that is distinct from our knowledge of the thing. Aristotle held that "definition is of what a thing is and of a reality,"76 or in other words, that the world as it is and the world as we define it are congruent, the so-called correspondence theory of truth. The key to knowledge in the Aristotelian scheme was understanding the universal itself as a "thing." To define a substance meant to establish its essential attributes, among various accidental ones, and to establish especially the one attribute that caused the substance to be as it is. The problem was to discern the "right" attributes that must be specified in the definition ${ }^{78}$ so that while each attribute might singly apply to other things, as a whole they would apply only to this thing.

trans. \& eds., Cambridge Univ. Press 1998) (1781). Related distinctions between the material and immaterial, and between idea and expression made their way into copyright law, where they persist. See 17 U.S.C. $\S 102$ (a) (2000) (rejecting copyright in processes and methods); 17 U.S.C. $\S 202$ (2000) (distinguishing copyrighted work from its tangible medium).

76 ARISTOTLE, POSTERIOR ANALYTICS 90b30-31 (Jonathan Barnes trans., Clarendon Press 1975) (350 B.C.E.) [hereinafter ARISTOTLE, POSTERIOR ANALYTICS]; see also ARISTOTLE, METAPHYSICS 1011 b25 (W.D. Ross trans., Clarendon Press 1924) (350 B.C.E.) [hereinafter ARISTOTLE, METAPHYSICS] ("To say of what is that it is not, or of what is not that it is, is false, while to say what is that it is, or of what is not that it is not, is true"); ARISTOTLE, The Categories 12b5, 14bl5 (Harold P. Cooke trans.), in THE ORGANON (Harvard Univ. Press 1938) (350 B.C.E.) (describing correspondence between statements of affirmation or denial, and the matters of fact (pragmata) that are affirmed or denied); ARISTOTLE, On Interpretation 16a3 (Harold P. Cooke trans.), in THE ORGANON supra (describing thoughts as representations or likenesses of objects). On the distinction between Aristotle's argument concerning essences and the distinct notion of "Platonic essence," see Maureen B. Cavanaugh, Order in Multiplicity: Aristotle on Text, Context, and the Rule of Law, 79 N.C. L. REV. 577, 634-38 \& n.206 (2001).

77 "An 'experience' in the Aristotelian sense was a statement of how things happen in nature, rather than a statement of how something had happened on a particular occasion." PETER DEAR, Discipline and EXPERIENCE: THE MATHEMATICAL WAY IN THE SCIENTIFIC REVOLUTION 4 (1995).

78 ARISTOTLE, POSTERIOR ANALYTICS, supra note 76, at 96al5. See generally ARISTOTLE, METAPHYSICS, supra note 76, at 1017b 27, 1029a 27-28 and Books VII-IX.

79 In the Aristotelian scheme, the true character of reality is shown via subject/predicate assertions, in which features or properties of things are shown to inhere in individual substances. Things of some kind have certain features, or predicates. "Substance" is the most crucial among the ten different kinds of predicates, since it describes the thing in terms of what it most truly is, the essence of the thing, not predicated on anything else. The other nine categories (quantity, quality, relative, where, when, being in a position, having, acting on, and being affected by) describe features that distinguish this thing from others of the same kind. Used in combination, the ten kinds of predicate provide a comprehensive account of what any individual thing is.

Substance therefore represents both essence (its form, or its intelligible character) and substratum (matter) of a thing. A substance possesses attributes but is the attribute of nothing. There remains a distinction, however, between essence (what the thing is in itself, not common to anything else, or what is necessary for its individual existence or for membership in a specific kind) and form (the intelligible, verbalized character of the thing). The essence of a thing is 
Modern extensions of this tradition not only inquire into the "proper" classification of things, but they use our descriptions and experiences of things as guides for identifying the "correct" features of things. Ontological and epistemological questions depend on questions of language and practice. ${ }^{80}$ Aristotle posited the close connection between essence and form. In his examinations of language, Wittgenstein expanded the scope of the inquiry in order to include the problem of related linguistic forms used to describe apparently dissimilar phenomena. Though Wittgenstein shifted the inquiry from the question of objective features of the thing to the question of proximity to prototypes, ${ }^{81}$ in an importance sense, his "family resemblance" analysis of language and concepts follows an essentially Aristotelian model. A conceptual category is not defined by the "true" features that defined each member of the category so much as the category is populated by members that resemble, to a greater or lesser extent, "core" members. ${ }^{82}$ Semioticians ask the related question of whether we are dealing with a category of things, an abstraction, as it were, or a particular exemplar or embodiment, that is, a type or a token. ${ }^{83}$ Ma-

what is formulated as a universal in the mind and in language. See CHARLOTte WITT, SUBSTANCE AND ESSENCE IN ARISTOTLE: AN INTERPRETATION OF METAPHYSICS (1994); GARTH L. HALLETT, ESSENTIALISM: A WITTGENSTEINIAN CRITIQUE (1991) (providing a theoretical sampling of essentialism).

${ }^{80}$ Language and function tell us what the thing is; they do not constitute the thing itself. On this point, I distinguish the thing-by-nature model from the thing-by-practice model, described infra in Part VI.

81 See Carl S. Bjerre, Secured Transactions Inside Out: Negative Pledge Covenants, Property, and Perfection, 84 CORNELl L. REV. 305, 353-64 (1999) (summarizing fruits of modern research on role of metaphor in conceptual reasoning and connecting that research to Wittgenstein).

82 See LudWig WITtgenstein, Philosophical Investigations $\$ \$ 66-69$ (G.E.M. Anscombe trans., 1968) (1953) (describing the concept of "family resemblance" as "a complicated network of similarities overlapping and criss-crossing: sometimes overall similarities, sometimes similarities of detail"); George Lakoff, The Contemporary Theory of Metaphor, in METAPHOR AND THOUGHT, 202 (Andrew Ortony ed., 2d ed. 1993) (describing "feature based" view of concepts as running from Aristotle through Wittgenstein). For illustrations of the Wittgensteinian approach in legal analysis, see Craig A. Nard, A Theory of Claim Interpretation, 14 HARV. J.L. \& TECH. 2 (2000) (discussing the Federal Circuit's use of interpretative theories when interpreting patent claims); Daniel J. Solove, Conceptualizing Privacy, 90 CAL. L. REv. 1087 (2002) (applying a Wittgensteinian approach to the concept of privacy); Steven L. Winter, Transcendental Nonsense, Metaphoric Reasoning, and the Cognitive Stakes for Law, 137 U. PA. L. REV. 1105 (1989). The "family resemblance" analysis is significant elsewhere, of course, not only in its Aristotelian sense, particularly as the theory moves farther from individual mental states and closer to shared experience. See infra notes 275-82 and accompanying text (situating Wittgenstein in the context of thing-by-practice).

${ }^{83}$ My invocation of semiotics literature is deliberate, though as I note later, modern semiotics is generally more preoccupied with relations among signifiers and the signified, rather than with things themselves. The type/token distinction comes from Peirce: the schematic aspect of a symbol is its type; a written sign itself is a token. Similar formulations of the distinction between a universal and an instance from others include Saussure's distinction between langue 
terialist epistemology asks the question of nature in terms of what the thing does, rather than in terms of how we talk about it. ${ }^{84}$

The practice of the essentialist technique in American law is largely divorced from its philosophical underpinnings, meaning that courts seek the "truth" of the thing without being genuinely concerned with whether the thing really exists. In law, Aristotelian methodology is not truly an ontological or an epistemological exercise, but an echo that uses related methods to achieve the relative certainty, durability, and predictability that genuine ontology is supposed to provide. To theorists of legal language and statutory interpretation, the Hart/Fuller debate over the character of statutory interpretation and language in the law ${ }^{85}$ may be framed as an argument over "core" versus "contextual" meanings of language, with Hart allegedly defending the former position and Fuller allegedly defending the latter. Both, however, accepted the importance of contextual understandings of legal language. They differed over the moral implications of that experience. As to meaning itself, however, both perspectives are, in the end, "essentially" Aristotelian. ${ }^{86}$

Because of the intuitive appeal of the essentialist approach, or what I call thing-by-nature, legal examples are legion. What the thing "is," according to some set of properties (whether identified abstractly or contextually), determines the outcome of the case. At times, courts are quite direct in their adoption of thing-by-nature. At the purer metaphysical end of the spectrum, there is Sherwood $v$. Walker, ${ }^{87}$ in which the Supreme Court of Michigan concluded that a "barren cow is substantially a different creature than a breeding one" 88 and accordingly supported the right of the seller, who believed that the cow was

(language, or scheme) and parole (talking) and Chomsky's distinction between competence (schema) and performance (instantiation or actualization). For a comprehensive review of basic semiotic theory and its application to trademark law, see Beebe, supra note 24.

84 See Davis Baird, Thing Knowledge-Function and Truth, 6 TECHNE: J. OF THE SOC'Y FOR PHIL. \& TECH. 13, 15 (2002) ("I claim that an artifact bears knowledge when it successfully accomplishes a function."). For the proposition that Aristotelian categories are really functional, see PETER MCLAUGhlin, What FunCtions EXPLAIN: FunCtional EXPLANATION AND SELFREPRODUCING SYSTEMS 42-61, 211 (2001).

85 See supra note 7 and accompanying text.

${ }^{86}$ Maureen Cavanaugh argues that this result better reflects the pragmatism of Aristotle, by reconciling the intuition that concepts and language have core meanings with the inevitability and necessity of looking to functional results in reaching ultimate conclusions. See Cavanaugh, supra note 76, at 629-42 (describing a functionalist dimension to the Aristotelian view of identity). See generally James Boyle, The Politics of Reason: Critical Legal Theory and Local Social Thought, 133 U. PA. L. REV. 685 (1985) (critiquing the conceptual possibility of objectivist or essentialist understandings of legal language, but noting division among critical scholars between pure subjectivists and structuralists).

8733 N.W. 919 (Mich. 1887).

${ }^{88}$ Id. at 923. 
barren, to rescind the contract after learning that the cow was pregnant. ${ }^{89}$ Judge Friendly's famous opinion in Frigaliment Importing Co. v. B.N.S. International Sales Corp. is renowned for its masterful and contextual exposition of contract interpretation, yet at its core the case raises a question of the thing; it opens with the line, "The issue is, what is chicken?"90 Comparable ontological premises inform McBoyle v. United States" (is an airplane a "motor vehicle"?); Nix v. Hedden $^{92}$ (is a tomato a vegetable?); United States v. 103 Electronic Gambling Devices $^{93}$ (what is bingo?); and Avon Products, Inc. v. S.C. Johnson \& Son, Inc. ${ }^{94}$ (what is insect repellant?). Rules that expressly mandate outcomes based on classifications lend themselves to the same approach. Interpretations of United States tariff classifications are replete with "is this an X?" questions, based on the essential characteristics of how the imported thing is used. ${ }^{95}$ As Justin Hughes notes in his recent work on geographical indicators, the authentic origin of the thing is largely a matter of ex ante definition. ${ }^{96}$ A similar

89 The court later limited Sherwood to its facts in Lenawee County Board of Health $v$. Messerly, 331 N.W.2d 203 (Mich. 1982), holding that rescission for mutual mistake must be based on a claim that the error goes to a "basic assumption" underlying the contract, see $i d$. at 209. In other words, the court replaced one metaphysical inquiry with another.

90190 F. Supp. 116, 117 (S.D.N.Y. 1960).

9I 283 U.S. 25 (1931).

92149 U.S. 304 (1893).

93223 F.3d 1091 (9th Cir. 2000).

94984 F. Supp. 768 (S.D.N.Y. 1997).

95 See, e.g., Rollerblade, Inc. v. United States, 112 F.3d 481 (Fed. Cir. 1997) (boots for inline skates); Benziger v. United States, 192 U.S. 38 (1904) ("casts of sculpture"); Pistorino \& Co. v. United States, 607 F.2d 989, (C.C.P.A. 1979) (beam cutting machines); United States v. Colibri Lighters (U.S.A.) Inc., 47 C.C.P.A. 106, 109 (1960) (parts for lighters); H.J. Baker \& Bros. v. United States, 37 C.C.P.A. 52 (1949) (sunflower seed meal); Amorient Petroleum Co. v. United States, 607 F. Supp. 1484 (Ct. Int'l Trade 1985) (motor fuels); Pistorino \& Co. v. United States, 461 F. Supp. 331 (Cust. Ct. 1978) (models); ACME Marble \& Granite Co. v. United States, 324 F. Supp. 503 (Cust. Ct. 1971) (shrines); Moral Re-Armament, Inc. v. United States, 317 F. Supp. 261 (Cust. Ct. 1970) (fine art). On the legal standards for applying tariff classifications, see generally Anhydrides \& Chemicals, Inc. v. United States, 130 F.3d 1481 (Fed. Cir. 1997). Cf. United States v. McClain, 545 F.2d 988 (5th Cir. 1977) (examining whether imported artifacts were "stolen").

Using functional characteristics to determine the essential identity of the thing appears in trademark law. See TrafFix Devices, Inc. v. Mktg. Displays, Inc., 532 U.S. 23, 33 (2001) (defining unprotectible functionality under trademark law acconding to whether the feature "is essential to the use or purpose of the device or when it affects the cost or quality of the device"); Qualitex Co. v. Jacobson Prods. Co., 514 U.S. 159, 165 (1995) (same). It also appears in antitrust law. See Fraser v. Major League Soccer, L.L.C., 284 F.3d 47, $55-58$ (1st Cir. 2002) (analyzing "single entity" question using functional benchmarks, but deciding case on assumption that the league is not a single entity, for Sherman Act section 1 purposes); $c f$. Copperweld Corp. v. Independence Tube Corp., 467 U.S. 752, 771 (1984) (describing "unity of interest" standard to capture the degree of corporate and economic integration among nominally distinct entities).

96 See Justin Hughes, The Spirited Debate Over Geographic Limitations (2004) (unpublished manuscript, on file with author). Authentic Champagne, for example, comes only from the Champagne region of France. A British law defines "scotch whisky." See The Scotch Whisky Order 1990, 1990 No. 998 (Eng.) (implementing The Scotch Whisky Act 1988, itself 
approach tends to govern "new use" problems in copyright law, in which some novel technological form must be evaluated for its congruence to some controlling legal instrument that fails to mention that form. Courts in these cases have responded largely by resorting to techniques of definition rather than by relying on techniques of contract interpretation (draft ambiguous language against the drafter, for example). A new use is (or is not) covered by an existing license depending on whether the new medium "is" or "is not" the medium specified in the license. ${ }^{97}$

Thing-by-nature, and its concern with the "true" or "authentic" nature of the thing, also plays a central foundational role in legal doctrines and traditions that do not clearly rely on what the thing "is." In this sense, the essentialist tradition in law is an appropriate starting point not only philosophically, but also historically, in the sense that much of the common law was premised on the world as it was found. Judges and commentators organized the law around it. Blackstone, for example, took "things" as they were understood to be given, in the classical sense of "external things in the world." might be either real or personal; chattels might be "real" (such as leaseholds, attached to real estate), or "personal." Common law prohibitions on restraints on alienation ${ }^{100}$ and injunctions against waste ${ }^{101}$

the successor to legislation that extends back to the turn of the twentieth century).

${ }_{97}$ See N.Y. Times Co. v. Tasini, 533 U.S. 483 (2001) (what is a newspaper?); Random House v. Rosetta Books, 150 F. Supp. 2d 613 (S.D.N.Y. 2001) (what is a book?), aff'd, 283 F.3d 490 (2d Cir. 2002); Boosey \& Hawkes Music Publishers, Ltd. v. The Walt Disney Co., 145 F.3d 481 (2d Cir. 1998) (what is a motion picture?); Cohen v. Paramount Pictures Corp., 845 F.2d 851 (9th Cir. 1988) (what is television?). Other "new use" cases of this sort include Paramount Publix Corp. v. Am. TriErgon Corp., 294 U.S. 464 (1935) (sound recordings); Manners v. Morosco, 252 U.S. 317 (1920) (motion pictures); Bartsch v. Metro-Goldwyn-Mayer, Inc., 391 F.2d 150 (2d Cir. 1968) (television); Ettore v. Philco Television Broad. Corp., 229 F.2d 481 (3d Cir. 1956) (television broadcasts); L.C. Page \& Co. v. Fox Film Corp., 83 F.2d 196 (2d Cir. 1936) (motion pictures with sound); Kirke La Shelle Co. v. Paul Armstrong Co., 188 N.E. 163 (N.Y. 1933) (motion pictures with sound).

98 Fred Yen points out that in its dependence on the world around it, the common law carried on a natural law tradition inherited from Roman law. He notes that the Roman system was structured to interrogate the world as it actually was; the common law was structured so as to assume a given world, a world that was as aspirational as real. See Alfred C. Yen, Restoring the Natural Law: Copyright as Labor and Possession, 51 OHIO ST. L.J. 517,532 n.37 (1990).

${ }_{99}$ Blackstone further distinguished between personal property attendant to real property (chattels real), such as leaseholds, and chattels personal, that is, chattels considered purely as movable goods. The bulk of Blackstone's description of the latter is directed to animals.

100 See William BLACKSTONE, 2 COMMENTARIES *398. Joan Williams argues that the fixed hierarchy of relationships among legal estates expressed the fixed social structure that characterized feudal society. The character of an estate in land, like the character of one's place in the Great Chain of Being, was simply given. See Joan Williams, The Rhetoric of Property, 83 IOWA L. REV. 277, 290-91 (1998).

101 See William BlaCkSTONe, 3 COMMENTARIES *224 (describing common law rules against waste); see also WILLIAM BLACKSTONE, 2 COMMENTARIES *281-84 (defining waste). In 
reflected the sense that the world was as it was given naturally and, both socially and physically, should remain essentially so. ${ }^{102}$ Men and markets should behave accordingly. ${ }^{103}$

Manifestations of this sense of the natural condition of things showed up in hostility to encumbrances on moveable goods, including (among other places) prohibitions on unnecessarily multiplying the types of legal interests in property (corresponding to the civil law numerus clausus principle), ${ }^{104}$ on "equitable servitudes" in chattels that purported to prohibit how they could be used, ${ }^{105}$ and on marketing arrangements that would be condemned under modern antitrust law as species of "tying" and "resale price maintenance" because they limited the terms on which goods could be bought and sold. ${ }^{106}$ In this

the United States the law of waste turned away from protection of the identical "thing" to protection of the economic interests of the future property owner. See Melms v. Pabst Brewing Co., 79 N.W. 738, 738-39 (Wis. 1899).

102 See TheOdore F.T. Plucknetr, A CONCISE History of the COMMON LAW 540-41 (5th ed. 1956) (tracing the prohibition on restraints on alienation to the Statute Quia Emptores of 1290$)$.

103 As Lord Coke wrote:

And so it is if a man be possessed of a lease for yeares, or of a horse, or of any other chattel reall or personall, and give or sell his whole interest or propertie therein upon condition that the donee or vendee shal not alien the same, the same is void, because his whole interest and propertie is out of him ....

EDWARD COKE, INSTITUTES OF THE LAWS OF ENGLAND; OR, A COMMENTARY UPON LITTLETON $223, \S 360$ (1628).

104 See Thomas W. Merrill \& Henry E. Smith, Optimal Standardization in the Law of Property: The Numerus Clausus Principle, 110 YALE L.J. 1 (2000) (arguing that the structure of the common law of property incorporates the policies underlying the numerus clausus principle).

${ }^{105}$ On the natural law implications of rules regarding equitable servitudes in chattels, see Thomas F. Cotter, Pragmatism, Economics, and the Droit Moral, 76 N.C. L. REv. 1, 53-54 (1997) (characterizing equitable servitudes as a form of moral rights); John M. Kernochan, The Distribution Right in the United States of America: Review and Reflections, 42 VAND. L. REV. 1407, 1413-15 (1989) (comparing copyright's first sale doctrine).

106 The Commentaries of Chancellor Kent, first published in 1826, married the English common law to the American economy of the nineteenth century, in a way that both reflected and anticipated a construction of legal "things" via the demands of the market, rather than as given by God. See JAMES KENT, COMMENTARIES ON AMERICAN LAW (Charles M. Barnes ed., Little, Brown and Co., 13th ed. 1884) (1826). The physical dimension of property retained its classic treatment, both under the doctrine of waste, see JAMES KENT, Lecture 35, in 2 COMMENTARIES ON AMERICAN LAW, supra, at 340-55, and under the doctrine of bailment. See JAMES KENT, Lecture 40, in 2 COMMENTARIES ON AMERICAN LAW, supra, at 559-611. Kent, however, laid the foundation for legal distinctions between the legal integrity and the physical integrity of things, by connecting the value of things to their marketability (in Kent's terms, alienability), rather than to their natural forms. See GREGORY S. AlEXANDER, COMMODITY \& PROPRIETY: COMPETING VISIONS OF PROPERTY IN AMERICAN LEGAL THOUGHT 1776-1970, at $138-39,141-47$ (1997) (noting the transition from Blackstone's physicalist view of property as "things" to Kent's view of property as legal interests in both things (i.e., objects) and land). The evolution anticipated by Kent was complete by the end of the century. Commentators concluded with confidence that in American law, the common law prohibition on restraints on alienation of personal property had entirely merged with (and overtaken) the common law premise that 
spirit, Adam Mossoff argues that modern patent law owes a debt to natural law concepts in the common law of property. ${ }^{107}$ Similarly, Jeanne Schroeder argues that the "grasped object," both physical and metaphoric, remains a central metaphoric concern of commercial law. ${ }^{108}$ Thomas Merrill concludes that federal constitutional property questions in due process and in takings cases tend to follow a "patterning" approach in trying to determine the thingness of property. The law tends to prescribe a set of criteria that an interest must have to qualify as "property," though the patterns themselves differ in takings and due process cases.

Intellectual property law offers a rich palette of examples of essentialist premises. All of patent law might plausibly be reduced to a single question: What is "the invention" to be protected by the patent right? The evolution of American patent doctrine can be mapped by the techniques that Congress and courts have mandated for answering this question. In the nineteenth century, the Supreme Court confirmed in Winans $v$. Denmead" ${ }^{110}$ that a patent covered the "thing" described in the patent, regardless of its form. By the end of that century, patent law practice had moved toward peripheral claiming, that is, defining

property in a thing was defined by the character of one's "estate." The demands of commerce required the conclusion that the definition of a "thing" was that it was owned, and limitations on the alienability of that thing (the most important dimension of ownership) were presumptively invalid. See, e.g., JOSEPH J. DARLINGTON, A TREATISE ON THE LAW OF PERSONAL PROPERTY 33-35 (1891); JAMES SCHOULER, A TREATISE ON THE LAW OF PERSONAL PROPERTY 19-21 (5th ed., 1918). In important respects, this conclusion begs the question of thingness itself, which is the extent to which a restraint may be validly imposed by characterizing the property transfer as involving less than a fee simple absolute. Legal formalism based on a naturalistic view of things persisted, see, e.g., JOHN CHIPMAN GRAY, RESTRAINTS ON THE ALIENATION OF PROPERTY 27881 (2d ed. 1895) (presenting a formalist analysis that distinguishes the validity of restraints imposed under different estates), but defenders of the faith shifted the ground of the debate from thingness itself to the relationship between thingness and function. Compare Merrill L. Schnebly, Restraints upon the Alienation of Legal Interests: II, 44 YALE L.J. 1186, 1200-01 (1935) (arguing that the grantor of personal property should have the power to declare that the conveyance involved less than complete ownership and thus impose an enforceable condition on the grantee's use and disposition of the item), with Zechariah Chafee, Jr., Equitable Servitudes on Chattels, 41 HARV. L. REV. 945 (1928) (arguing that equitable servitudes on chattels ordinarily should not be enforced). Where thingness remains important in the law, it is typically the truth of the idea of the thing that is really paramount, rather than the truth of the thing itself. Philosophical distinctions between the two are not particularly important. A weak form of social construction theory applies in the end. Cf. Robinson, supra note 38, at 1483-85 (arguing that the policy justifications for the modern rule against restraints on alienation are empty, and that the rule rests not on a common law version of the numerus clausus principle of property law, but on an underlying assumption about the nature of objects).

107 See Adam Mossoff, Rethinking the Development of Patents: An Intellectual History, 1550-1800, 52 HAST. L.J. 1255 (2001).

108 Jeanne L. Schroeder, Some Realism About Legal Surrealism, 37 WM. \& MARY L. REV. 455, 491 (1996).

109 Merrill, supra note 40, at 927.

11056 U.S. (15 How.) 330, $342-43$ (1853). 
the scope of the patent according to the outer boundaries of the invention, rather than according to its central inventive characteristic. ${ }^{111}$ Congress confirmed that technique in the 1870 revision and recodified it in the 1952 Patent Act. As a result, the rule of Winans has been reinterpreted as early support for what we now know as the Doctrine of Equivalents. ${ }^{112}$ The change in claiming technique, however, has not changed the underlying character of the inquiry. By one device or another, the question for patentees and alleged infringers is whether the thing made, used, or sold by the latter is the very thing that is covered by the patent. The paradoxical nature of the question-its search for authenticity, coupled with ever more arcane rules for construing the relevant patent claims ${ }^{113}$-reinforces the sense that patentable things are constructed by the law, but that the law is striving to understand their essential or "true" character.

The process of claim construction is not the only place in patent law where essentialist reasoning dominates the search for the relevant thing. Patent law has labored to divine the distinction between "repair" and "reconstruction" of a patented invention by a customer who obtained a patented device legitimately, then wore it out. Since patent law grants the owner of a patent the exclusive rights to make and use the invention, a user of a patented device who repairs the device (by replacing a worn part, for example) might be accused of "making" that device anew. The Federal Circuit and predecessor courts have clung to the notion that the owner of the device may "repair" it so long as the device is not "spent" and maintains its original "identity," concepts that derive from the Supreme Court's early decision in Wilson $v$. Simpson. ${ }^{114}$ The analytic technique here is not precisely the

111 See Warner-Jenkinson Co. v. Hilton Davis Chem. Co., 520 U.S. 17, 35 (1997). Joshua Samoff views this history as support for an argument that the modern Doctrine of Equivalents in patent law originated as part of the practice of central claiming and has no relevance to a system of peripheral claiming. See Joshua Sarnoff, The Historic and Modern Doctrines of Equivalents and Claiming the Future: Part I (1790-1870), 87 J. PAT. \& TRADEMARK OFF. SOC'Y 441 (2005).

112 See Festo Corp. v. Shoketsu Kinzoku Kogyo Kabushiki Co., 535 U.S. 722, 723 (2002) (citing Winans for the proposition that "a patent's scope is not limited to its literal terms, but embraces all equivalents to the claims described").

113 See Phillips v. AWH Corp., 415 F.3d 1303 (Fed. Cir. 2005) (en banc).

11450 U.S. ( 9 How.) 109, 126 (1850) (finding no patent infringement where the defendant replaced knives that were part of the invention, where the nature of the invention demanded replacement of knives at periodic intervals; the "identity of the machine" was not altered); see also Morgan Envelope Co. v. Albany Perforated Wrapping Paper Co., 152 U.S. 425, 433 (1894) (finding no infringement by a defendant who sold paper usable in connection with a patented toilet paper fixture, "where the element made by the alleged infringer is an article of manufacture perishable in its nature, which it is the object of the mechanism to deliver, and which must be renewed periodically, whenever the device is put to use"). The leading modern case is Aro Manufacturing Co. v. Convertible Top Replacement Co., 365 U.S. 336 (1961) (finding no infringement by a defendant who replaced the worn fabric of a patented but worn automobile 
same as the one used in "new use" cases in copyright law. The question is not identity of media, but a different, though related issue of identity: does the machine as rebuilt by the alleged infringer share an "identity" with the machine patented by the patentee-or merely with the machine purchased by the alleged infringer in the first place? What, in short, is the essence of the patentee's invention? Is the reconstructed version the same thing?

Mark Janis points out that judicial adherence to the "identity" concept has been erratic, and it has been coupled with equally erratic (and sometimes simultaneous) adherence to the notion of "intent," as in, what did the parties to the original transaction intend regarding the scope of repair and reconstruction rights ${ }^{115}$ It is said, accordingly, that the patentee's patent interest is "exhausted" by an unrestricted sale of the patented item, such that the patentee has received a full reward on account of the sale. ${ }^{116}$ Nonetheless, strong echoes of adherence to some form of "identity" test persist, as suggested in the Federal Circuit's recent rulings in Husky Injection Molding Systems Ltd. $v . R \& D$ Tool Engineering Co., ${ }^{117}$ Jazz Photo Corp. v. International Trade Commission, ${ }^{18}$ and Bottom Line Management, Inc. v. Pan Man, Inc. ${ }^{119}$

convertible top). The related doctrine of exhaustion of the patent right is traceable to Adams $v$. Burke, 84 U.S. (17 Wall.) 453 (1873) (coffin lids) and Bloomer v. McQuewan, 55 U.S. (15 How.) 539 (1852) (planing machines).

115 See Mark D. Janis, A Tale of the Apocryphal Axe: Repair, Reconstruction, and the Implied License in Intellectual Property Law, 58 MD. L. REv. 423 (1999) (criticizing "spentness rhetoric" that distinguishes repair from reconstruction, because it encourages courts to consider the physical qualities of the subject devices in a vacuum, rather than using qualities as proxies for underlying expectations of patentee and purchaser).

116 See Jazz Photo Corp. v. Int'l Trade Comm'n, 264 F.3d 1094, 1105 (Fed. Cir. 2001). So that the rule is consistent with the territorial effect of the patent laws, the relevant sale must occur within the United States. See Fuji Photo Film Co. v. Jazz Photo Corp., 394 F.3d 1368 (Fed. Cir. 2005).

117291 F.3d 780 (Fed. Cir. 2002) (finding no infringement of plaintiff's patented injection molding system by supplying unpatented carrier plates to plaintiff's customers, for use in the system). The court distinguished three scenarios: first, possible reconstruction of a "spent" patented item (an inquiry that involves several factors, including the nature of the device, the patentee's intent, and the character of the market for servicing components of the item); second, replacement of a spent unpatented part, which never constitutes infringement; and third, replacement of an unspent unpatented part, which enables the patented machine or process to perform better or differently. This third category is "akin to [permissible] repair." Id. at 787.

118264 F.3d 1094 (Fed. Cir. 2001) (holding that reconditioning of bodies of patented "single-use" cameras does not involve infringing "reconstruction," since the reconditioning preserves the life of the original article, rather than making a substantially new article). The line between permitted repair of an unpatented part of the invention and unpermitted reconstruction of the entire thing reconstitutes the "nature of the thing" question in a different analytic framework. See, e.g., Kendall Co. v. Progressive Med. Tech., Inc., 85 F.3d 1570 (Fed. Cir. 1996); Sage Prods., Inc. v. Devon Indus., Inc., 45 F.3d 1575 (Fed. Cir. 1995).

119228 F.3d 1352 (Fed. Cir. 2000) (holding that a company that repaired the surfaces of 
A final example of essentialist or thing-by-nature approaches in intellectual property law comes from subject matter distinctions both within and between copyright and patent law. Based on the premise that a given form of inventive or creative activity should be regulated primarily by one system of law, we want to know what should be regulated by intangible property systems and what should be regulated by other systems. We also want to know which intangible property system applies.

Certain technologies raise especially acute problems of both sorts. The most obvious problem case involves the computer program: ${ }^{120}$ Is the program a form of copyrightable expression, or is it a patentable machine or process? What kind of "thing" is a computer program? The doctrine currently proposes that the answer is a Berra-esque "both"- a result that appears to derive from analytic and precedential processes that have focused mostly on the true character of computer programs. The earliest attempts to categorize computer programs arose in a technological era in which programs and the machines that ran them were tightly integrated. Courts nonetheless insisted on distinguishing physical (substrate) and intangible (inventive or creative) forms in which programs were embodied, and distinguishing "expressive" and "inventive" dimensions of the program from "natural" rules and from "ideas." The result is a barely coherent body of law defining the circumstances under which computer programs are patentable and copyrightable. In the search for the essential thingness of the computer program, the law has concluded that computer programs, by their nature, are simultaneously both intangible things and tangible things, patentable machines and copyrightable expression.

On the patent side, the early history of computer technology coincided with the Supreme Court's decision in Gottschalk v. Benson, ${ }^{121}$ which forbids the patenting of a computer program that is nothing more than an electronic representation of a mathematical algorithm. That is, a computer program is not a thing at all. It is math. ${ }^{122}$ That decision has been buried, if not overruled, by the Federal Circuit's

patented cooking plates was engaged in permissible repair, since the repair affected unpatented components).

120 The "useful article" doctrine in copyright law, which tries to distinguish function from expression, is a similar example of a subject matter distinction based on the nature of the thing. See 17 U.S.C. \& 101 (2000) (defining "pictorial, graphic, and sculptural works" and "useful article"); Poe v. Missing Persons, 745 F.2d 1238, 1242 (9th Cir. 1984) (asking whether the work is a swimsuit, or a work of conceptual art).

121409 U.S. 63 (1972).

122 See Pamela Samuelson, Benson Revisited: The Case Against Patent Protection for Algorithms and Other Computer-Program Related Inventions, 39 EMORY L.J. 1025 (1990). 
holding in State Street Bank \& Trust Co. v. Signature Financial Group, Inc. ${ }^{123}$ that a device or method (such as a computer program) is patentable if it naturally produces a specific, tangible, useful result. A computer program is now a machine, a tangible thing (in patentese, an "article of manufacture") so long as it generates a result. Patent law achieved roughly the same result via the early theory that a "general purpose computer" loaded with a computer program inherently became a distinct and thing-like "special purpose computer," entitled to patent protection. ${ }^{124}$ In this case, one thing turns into a different thing, and it becomes patentable along the way.

On the copyright side, the law likewise has tried to maintain a sense of the "true" nature of a computer program. Copyright law accepts computer programs as protectible works of authorship because they exist, as a matter of course, in "literary" form, that is, as recitations of text that instantiate copyrightable "expression." 25 Material excluded from copyright when it appears in novels and playsmaterial characterized as "merger" (the tight integration of idea and expression) and "scenes à faire" (the stock or standard representations)-is likewise excluded from protection when it appears in a computer program. ${ }^{126}$ The very nature of a computer program, in other words, is to be a literary work. The computer program is, however, also irreducibly functional, and so copyright has simultaneously and awkwardly tried to limit its scope with respect to "genuinely"

123149 F.3d 1368 (Fed. Cir. 1998).

124 A "general purpose computer in effect becomes a special purpose computer once it is programmed to perform particular functions pursuant to instructions from [particular] program software." WMS Gaming, Inc. v. Int'l Game Tech., 184 F.3d 1339, 1348 (Fed. Cir. 1999) (quoting In re Alappat, 33 F.3d 1526, 1545 (Fed. Cir. 1994) (en banc)); cf. In re Bernhart, 417 F.2d 1395,1400 (C.C.P.A 1969) ("[I]f a machine is programmed in a certain new and unobvious way, it is physically different from the machine without that program; its memory elements are differently arranged."); see Julie E. Cohen \& Mark A. Lemley, Patent Scope and Innovation in the Software Industry, 89 CAL. L. REv. 1, 10 (2001) (summarizing evolution of Federal Circuit's rules on patenting computer programs); $c f$. Lotus Dev. Corp. v. Borland Int'1, Inc., 49 F.3d 807 (1st Cir. 1995) (holding computer program "command hierarchy" unprotected by copyright law as a "method of operation"), aff'd by an equally divided Court, 516 U.S. 233 (1996).

125 This is the premise that underlies application of Judge Hand's abstractions test for evaluating infringement of dramatic works, such as plays, to computer programs. See Computer Assocs. Int'l, Inc. v. Altai, Inc., 982 F.2d 693 (2d Cir. 1992). In its effort to disassemble the computer program function-by-function in search of its expressive essence, the Altai case is generally contrasted with the earlier opinion of the Third Circuit in Whelan Associates v. Jaslow Dental Laboratory, Inc., 797 F.2d 1222 (3d Cir. 1986), which took a more holistic view of the program as work of authorship.

${ }^{126}$ See Computer Assocs., 982 F.2d at 714-17. The usefulness of the literary analogy has been thoughtfully explored in the context of broader examinations of computer programs. See Lloyd L. Weinreb, Copyright for Functional Expression, 111 HARV. L. REV. 1149, 1209 (1998) (characterizing doctrinal allocation of copyright interests in computer programs as based largely on convention). 
functional dimensions. ${ }^{127}$ A computer program may embody unprotected "methods of operation," 28 and competitors of the copyright owner have been given leeway to engage in the kind of reverse engineering of functional things that is afforded the owners of objects that embody trade secrets. ${ }^{129}$

Distinguishing the "natural" from the "artificial" with respect to a computer program dovetails with the broader intellectual property principle that limits legal protection to that which humans create, expressed in the patent law as the prohibition on patent protection for "products of nature."130 "Products of nature" cannot be patented unless they can be recharacterized as "things." As Judge Learned Hand concluded in Parke Davis v. H.K. Mulford, ${ }^{131}$ ruling that a purified form of the extracted substance known as adrenalin could be patented because "it became for every practical purpose a new thing commercially and therapeutically." 132 As flimsy as this argument is, it

${ }^{127}$ The author John Hersey dissented from the CONTU Report on the ground that computer programs were primarily and essentially functional. NAT'L COMM'N ON NEW TECHNOLOGICAL USES OF COPYRIGHTED WORKS, FINAL REPORT OF THE NATIONAL COMMISSION ON NEW TECHNOLOGICAL USES OF COPYRIGHTED WORKS 27-28 (1979); DAVID

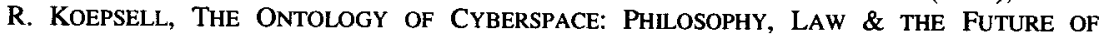
INTELLECTUAL PROPERTY (2000) (arguing, following John Searle, for a materialist interpretation of computer-generated objects, i.e., that they consist of ordinary objects (like electrical charges) in computer equipment, and therefore do not belong in the legal universe that regulates "expression"). The crude ontological approach to new technologies has led courts down some awkward paths with respect to the existence of infringing "copies" of copyrighted works. Compare MAI Sys. Corp. v. Peak Computer, Inc., 991 F.2d 511, 519 (9th Cir. 1993) (finding a temporary RAM reproduction of a computer program to be an infringing "copy"), with WhiteSmith Music Publ'g Co. v. Apollo Co., 209 U.S. 1, 17 (1908) (finding that a player piano roll did not comprise a "copy" of a copyrighted musical composition).

${ }^{128}$ See Lotus Dev. Corp., 49 F.3d 807; Dennis S. Karjala, Distinguishing Patent and Copyright Subject Matter, 35 CONN. L. REv. 439, 509-10 (2003) (arguing for a broad view of the functional dimensions of computer programs, and that "functional" expression generally should be categorically assigned to the patent system).

${ }^{129}$ See Sega Enters. Ltd. v. Accolade, Inc., 977 F.2d 1510 (9th Cir. 1992). Permission to reverse engineer copyrighted program code helps to reinforce the distinction between copyright and patent systems; in the latter, reverse engineering usually infringes. Enforcement of contractual arrangements that limit reverse engineering of copyrighted works weaken that distinction, by muddying the waters regarding the kind of "thing" a given work is. See Bowers v. Baystate Techs, Inc., 320 F.3d 1317 (Fed. Cir. 2003) (enforcing a contract term that prohibited software licensee from reverse engineering the licensed program).

130 See Funk Bros. Seed Co. v. Kalo Inoculant Co., 333 U.S. 127 (1948); O'Reilly v. Morse, 56 U.S. (15 How.) 62 (1853) (holding that abstract principles are not patentable subject matter); Richard S. Gruner, Intangible Inventions: Patentable Subject Matter for an Information Age, 35 LOY. L.A. L. REV. 355, $371-72$ (2002); Dan L. Burk, Software as Speech, 8 SETON HALL CONST. L.J. 683, 690 (1998).

${ }^{131} 189$ F. 95 (S.D.N.Y. 1911), aff'd, 196 F. 496 (2d Cir. 1912).

132 Id. at 103; see also Merck \& Co. v. Olin Mathieson Chem. Corp., 253 F.2d 156, 162 (4th Cir. 1958) (holding that a purified form of an existing natural product is patentable only if the new product differs from the old in kind, not merely degree). The origins of the term "manufacture" as a predicate for patent protection in these cases offers additional support for an essentialist reading of thingness in patents. See Allen Bloom, Designer Genes and Patent Law: A Good Fit, 26 N.Y.L. SCH. L. REV. 1041, 1043-44 (1981) (noting origins of the patent term 
has been adopted as a justification for allowing patents on isolated genetic sequences. A sequence of genetic codons chemically isolated from its chromosomal context can be patented because that "thing" does not exist as such in any natural state and therefore has been "made by man." 133 From such a denaturalizing, decontextualized perspective, under this regime anything may be, or become, a thing. ${ }^{134}$

For all of the flaws of an essentialist or thing-by-nature approach, from a policy standpoint the approach has some obvious and important virtues. The most important one is the relative stability and consistency of the things that it produces. Things usually are as they appear to be, and they usually should and do remain the same across contexts. If we conclude in one domain that a thing is a thing and a certain kind of thing, then it should retain that status if either we are or the thing is transposed to some other domain. To make this abstract example concrete, if I conclude that something is "television" for purposes of a copyright case, then it is likely right that this medium should be treated as "television" for antitrust law, telecommunications law, and commercial law. For example, whether broadband Internet service to the home is a "cable service" or a "telecommunication ser-

\footnotetext{
"manufacture" in customs cases levying import duties on manufactures and distinguishing raw materials).

${ }^{133}$ See Utility Examination Guidelines, 66 Fed. Reg. 1092, 1093 (Patent and Trademark Office Jan. 5, 2001); Linda J. Demaine \& Aaron Xavier Fellmeth, Reinventing the Double Helix: A Novel and Nonobvious Reconceptualization of the Biotechnology Patent, 55 STAN. L. REV. 303 (2002) (urging rejection of the "isolation and purification" standard for patentability). The proposition that genetic sequences are patentable according to their structure, rather than function, is heavily criticized in Robin Cooper Feldman, Rethinking Rights in Biospace, $79 \mathrm{~S}$. CAL. L. REV. 1 (2005).

${ }^{134}$ Compare Bayer AG v. Housey Pharm., Inc., 340 F.3d 1367 (Fed. Cir. 2003) (finding no patent infringement where imported result of foreign use of patentee's process was "information," not a product), with AT\&T v. Microsoft Corp., No. 01 Civ. 4872(WHP), 2004 WL 406640 (S.D.N.Y. Mar. 5, 2004) (holding that exporting a master copy of a computer program constituted exporting a component of a patented program-related invention, rather than "mold" for a component of the invention), aff'd on other grounds, 414 F.3d 1366 (Fed. Cir. 2005), and Eolas Techs. Inc. v. Microsoft Corp., No. 99 C 0626, 2004 WL 170334 (N.D. Ill. Jan. 15, 2004) (rejecting defendant's argument that it is not liable for sales of infringing computer programs, where each infringing copy was not embedded in tangible media), vacated in part, 399 F.3d 1325 (Fed. Cir.), cert. denied, 126 S. Ct. 568 (2005). The Eolas patent at issue in the last of these cases was later invalidated as a result of a reexamination proceeding in the Patent Office. See also SmithKline Beecham Corp. v. Apotex Corp., 365 F.3d 1306, 1329 (Fed. Cir. 2004) (Gajarsa, J., concurring) (concluding, in a bioscience context, that the patent failed to disclose patentable subject matter where there is no discrete "thing," since the technology involved a patented "thing" that was spontaneously and automatically created by production of a nonpatented thing), vacated and petition for reh'g en banc granted, 403 F.3d 1328 (Fed. Cir. 2005) (vacating opinion as to experimental use). For a recent objection to this approach, see Eileen $\mathrm{M}$. Kane, Splitting the Gene: DNA Patents and the Genetic Code, 71 TENN. L. REV. 707, 752 (2004) (urging application of the "law of nature" doctrine to bar patents on DNA sequences, partly on the ground that the "essential attributes" of the genetic code describe a fixed, universal, and timeless relationship).
} 
vice" under the Communications Act of 1934 implicates not only the scope of applicable telecommunications regulation, but also the character of competition policy. ${ }^{135}$ Philosophically speaking, a thing should not have a different existence simply because a different set of legal principles is applied. ${ }^{136}$

In addition, thing-by-nature is comparatively cheap. Legal regulation is relatively straightforward. ${ }^{137}$ Lawmakers only have to describe the here and now of an object, as opposed to perspectives on an object, and they are not required to anticipate how things may change in the future. Cognitively, there is a related universality and finality that appears to attach to definitions of things. This is especially true for definitions that appear in statutes, but it is equally relevant to judicial analysis. Clarisa Long makes this "cognitive economy" the centerpiece of her analysis of copyright and patent interests; ${ }^{138}$ Thomas Merrill and Henry Smith make a related argument in support of their theory that property law generally allows recognition of a limited number of legal forms. ${ }^{139}$ Having to decide what television "is" in the first place is expensive enough; reconsidering the thingness of television every time a new suit is brought is intellectually wasteful. It generates uncertainty among commercial players, it engages legal institutions in problematic semantic exercises, and it leaves confusion and skepticism among consumers. We expect categories. At an individual level, it can be difficult to keep multiple senses of television alive in one's head. At a social level, if we cannot agree on what television is in some stable sense, how can we watch our favorite shows? Cultural

${ }^{135}$ See Nat'l Cable \& Telecomm. Ass'n v. Brand X Internet Serv., 125 S. Ct. 2688 (2005) (concluding that the Federal Communications Commission plausibly construed the Communications Act to characterize cable broadband internet service as an "information service"); MediaOne Group, Inc. v. County of Henrico, 257 F.3d 356 (4th Cir. 2001) (concluding that local "equal access" regulation applicable to Internet access provider unlawfully required provider to supply "telecommunication service" in violation of federal regulatory scheme); Rob Frieden, The FCC's Name Game: How Shifting Regulatory Classifications Affect Competition, 19 BERKELEY TECH. L.J. 1275 (2004) (urging abandonment of classification-based regulatory system). Part of the conceptual problem derives from what Orin Kerr has characterized as the problem of choosing between "internal" and "extemal" perspectives on computer technology. See Orin S. Kerr, The Problem of Perspective in Internet Law, 91 GEO. L.J. 357 (2003).

136 For discussions of the problems that ensue from different regulatory classifications of the same underlying things, see Raymond Shih Ray Ku, Irreconcilable Differences? Congressional Treatment of Internet Service Providers as Speakers, 3 VAND. J. ENT. L. \& PRAC. 70 (2001); Raymond Shih Ray Ku, Open Internet Access and Freedom of Speech: A First Amendment Catch-22, 75 TUL. L. REV. 87, 127-34 (2000).

137 See Douglas A. Kysar, Preferences for Processes: The Process/Product Distinction and the Regulation of Consumer Choice, 118 HARV. L. REV. 525 (2004) (arguing that policymakers pay insufficient attention to legitimate process-oriented consumer concerns in regulating potentially harmful or dangerous goods).

138 See Long, supra note 4, at 540 (arguing that thingness is a cognitive heuristic that reduces information processing costs).

139 See Merrill \& Smith, supra note 104, at 24-42. 
practice demands some basic agreement on what things are. The best argument in favor of an essentialist approach may be the fact that there is an irreducible and inescapable extent to which weindividuals and institutions-manage our lives and worlds in this way. ${ }^{140}$

\section{THING-BY-DESIGN}

The universality of thing-by-nature is its greatest strength. The authority of such a thing is literally irresistible and apparently indisputable. Yet legally as well as philosophically, thing-by-nature runs some major risks. A system that searches for and enforces the truth of a thing - even the truth of the idea of a thing - may get the answer wrong, with potentially catastrophic results. The unknowability of things was the centerpiece of Kant's philosophy; for lawyers, as an epistemological matter, Learned Hand may have put his finger on the problem with what is known as the "abstractions" test for distinguishing protectible expression in copyright from unprotectible idea. ${ }^{141} \mathrm{We}$ can never really know what the right level of abstraction is. Is this a thing itself, or merely a feature of a larger thing, or part of a system? What is the thing? There may be more than one. What is worse, things change, ${ }^{142}$ but thing-by-nature assumes that the world does not. And the virtues of "cognitive economy" conceal important "who" and "how" questions: who does the thing-making, and how does it get done ${ }^{143}$ Wittgensteinian "family resemblance" analysis of language

140 This conclusion forms the point of departure for the Realist and critical critique of property. See Thomas C. Grey, The Disintegration of Property, in 22 NOMOS: PROPERTY 69 (J. Roland Pennock \& John W. Chapman eds., 1980) (describing the distinction between the intuitive image of property, as absolute power over things, and the more "sophisticated," Hohfeldian, legal view of property as relationships among people (citing BRUCE ACKERMAN, PRIVATE PROPERTY AND THE CONSTITUTION 97-100, 113-67 (1977))). Grey's dichotomy is between laypeople and experts, whom he identifies as lawyers and economists. Id.; cf. Vandevelde, supra note 26 (describing the evolution of the "dominion" view of property).

141 As Judge Hand wrote:

Upon any work, and especially upon a play, a great number of patterns of increasing generality will fit equally well, as more and more of the incident is left out. The last may perhaps be no more than the most general statement of what the play is about, and at times might consist only of its title; but there is a point in this series of abstractions where they are no longer protected, since otherwise the playwright could prevent the use of his "ideas," to which, apart from their expression, his property is never extended. . . . Nobody has ever been able to fix that boundary, and nobody ever can.

Nichols v. Universal Pictures Corp., 45 F.2d 119, 121 (2d Cir. 1930).

142 See, e.g., Massachusetts v. Microsoft Corp., 373 F.3d 1199, 1239 (D.C. Cir. 2004)

(questioning the extent to which a court should intervene in product design decisions in the context of a dynamic market).

143 See Lawrence Lessig, The Architecture of Innovation, 51 DUKE L.J. 1783, 1784-85 (2002) (noting that the value of property is taken for granted, so that people ask who will control it, rather than whether to control it). 
has been challenged by cognitive linguists, who argue that language, thought, and reality are isomorphic not at the level of "true" features found in the world, but at the level of ordinary experience. The focus on the true nature of things undermines our common understanding that we really do make the world around us, that we manufacture meaning along with manufacturing things, and that creators of things are presumptively entitled to define both. ${ }^{144}$ Jed Rubenfeld suggests that copyright law and the First Amendment can be unified under a rubric that he describes as the "freedom of imagination," 145 a freedom that likely embodies not only autonomy to play inside the mind, but also autonomy to represent one's thoughts in material form. ${ }^{146} \mathrm{Phi}$ losophically, Aristotelian monism is a short step from Cartesian dualism that places cognition ahead of perception. We have the ability to create our "reality" and then to characterize it. This emphasis on a power and the right-to-design is a move toward a moral foundation for thingness and away from a foundation based on intuition. In many cases, the law presumes that our ability to create this reality justifies an entitlement to do so. Things are what we design them to be.

The shift from thing-by-nature to thing-by-design reflects evolution from the Kantian and Aristotelian traditions noted in the previous Part, on the one hand, and toward later philosophers, including and especially Hegel, on the other. Philosophically speaking, the basic framework that analyzed the world as it was in terms of the world as we perceived it, inherited from the ancient Greeks, ${ }^{147}$ remained intact, but it was liberated from a theological assumption that the perfect, true universe could only be the product of divinity (and the correspondingly measured role for individual autonomy). ${ }^{148}$ Kant, like Ar-

144 One might be tempted to draw a sharp distinction between the material flexibility that I described in Part $\Pi$ and interpretive flexibility, and so reconcile what I call thing-by-nature with our entitlement to make meaning from the world. One of my premises, following my constructivist take on the problem of materiality in the first place, is that these two sorts of flexibility are far less distinct than they appear. See also supra note 9 and accompanying text (describing Quine's critique of the analytic/synthetic distinction).

\section{L.J. 1 (2002).}

145 Jed Rubenfeld, The Freedom of Imagination: Copyright's Constitutionality, 112 YALE

146 See Jack M. Balkin, Virtual Liberty: Freedom To Design and Freedom To Play in Virtual Worlds, 90 VA. L. REV. 2043, $2079-80$ (2004). Balkin argues that the "freedom to design" of virtual worlds game developers may be worthy of constitutional significance under the First Amendment. As design edges towards commodification, it may be overridden by property and contract rules and by public regulation.

147 Aristotle and Kant stand in for a rich tradition exploring the roles of the real and ideal, material and immaterial, and subject and object. See Gary Peller, The Metaphysics of American Law, 73 CAL. L. REV. 1151, 1154, 1264, 1290 (1985).

148 See James BaRRY, JR., MEASURES OF SCIENCE: TheOlogical AND TECHNOLOGICAL IMPULSES OF EARLY MODERN THOUGHT (1996). Barry draws a distinction between knowing as appearance and perception in earlier (especially Aristotelian) frameworks, on the one hand, and the later conclusion (Descartes, Newton, and eventually Kant) that reality was instead based on 
istotle, could ask whether "things" are defined by our perceptions of them, or by what lies behind the perceptions, because he assumed that things themselves were given by God. Hegel postulated a world created by man, so that a "thing" consisted of that which was alienated from the self. An act of will was required. Given that, it was a short step to conclude that the object consisted of that which the individual had elected to alienate-and thus was definable by the individual in the first place.

For Hegel, a "thing" was the extension of the personality of the subject into the world of the object. As Radin notes, Kant and Hegel shared a basic concern with objects "separate from the self." 149 "If the person/thing distinction is to be treated as a bright line that divides the commodifiable from the inalienable, we must know exactly which items are part of the person and which not." 150 Hegel viewed "things" as external objects (contrasted with internal things) that exist without a free will ${ }^{151}$ and that can be possessed in property. ${ }^{152}$ For Kant, the difficult question was the relationship of the individual will to objects found in the world. Hegel answered this question by postulating that objects in the world are defined by the acts of will that created and defined them. The act of will that creates the thing simultaneously defines it.

knowing, and thinking, on the other hand. Aristotelian theory favored the perception of the senses, that knowledge derived ultimately from perception of things-in-the-world, that is, physical science descended from common sense. Cartesian (and eventually Newtonian and Kantian) thought granted immaterial-unobservable-things, such as forces, the status of real or natural things, favoring the role of the intellect. Newton confirmed this view: material things were theoretically shaped bodies, framed by the force of absolute space-time. Time and space, among other things, were elevated to "real" status. In Barry's formulation, however, Newtonian science still depended on "the things themselves" as recapitulations of the divine universal, i.e., as immanent theoretical structures that could be natural and therefore real only if they were ultimately produced by God. See id. at 153-55.

${ }_{149}$ Margaret Jane Radin, Contested Commodities 34 (1996).

150 Id. at 40.

151 G.W.F. HegEl, ELEMENTS OF THE PHILOSOPHY OF Right (Allen W. Wood ed., H.B. Nisbet trans., 1991) (1821) "“[T] external to my freedom, including even my body and my life. This right of things is the right of personality as such." Id. at 71 . What is an "object"?

[A]nything that is not capable of becoming a subject-that which has no will and cannot achieve self-consciousness. Objects are those things that may properly be treated as ends. ...

One implication of this is that there are no "natural" objects. An object obtains its status by its identification as such by an act of will by an individual seeking to become a subject.

Jeanne L. Schroeder, Unnatural Rights: Hegel and Intellectual Property 12 (Cardozo Law, Legal Studies Research Paper No. 80, 2004), available at http://papers.ssrn.com/ abstract $=518182$. Objects might be conceptual as well as tangible. See HEGEL, supra, at 74-75. The question is whether something can be given an external existence and disposed of. is2 See J.E. PENNER, THE IDEA OF PROPERTY IN LAW 175-80 (1997). 
I describe the Hegelian framework to point out that thing-bydesign ultimately relies on the broader intellectual construct that is personal autonomy. It has a specific and important intellectual lineage that is manifested both in American law and elsewhere in American thought and culture. For example, the history of other social sciences during the twentieth century reflects recognition of the implications of our ability both conceptually ${ }^{153}$ and physically ${ }^{154}$ to create and redefine ourselves and the world around us. Scholars as diverse as Herbert Simon $^{155}$ and Leo Marx ${ }^{156}$ have commented on the profoundly artifi-

153 There are a number of related intellectual movements that focus on truth and/or meaning as dependent on our use of language, rather than on knowledge of the world itself. Nominalism denies the objective reality of the sorts, or kinds, that define a proper ontology and asserts that naming alone produces meaning. See SAUL KRIPKE, NAMING AND NECESSITY (1980); Hilary PUTNam, The Meaning of "Meaning," in 2 Mind, Language and Reality 215 (1975); W.V.O. QUINE, Natural Kinds, in ONTOLOGICAL RELATIVITY AND OTHER ESSAYS, supra note 9, at 114-38. Intentionality locates both reality and meaning in the cognitive relationship between some belief or thing and what that belief represents. See JOHN SEARLE, INTENTIONALITY: AN ESSAY IN THE PhILOSOPHY OF MIND (1983); JoHN HAUGELAND, HAVING THOUGHT: ESSAYS IN THE PHILOSOPHY OF MIND (1998). Haugeland distinguishes theories of intentionality that locate it primarily in individual mental states, an approach associated with Jerry Fodor; those that locate it in environmentally situated agents, associated with Daniel Dennett and W.V.O. Quine; and those that locate it in the social and cognitive practices of a community, associated with Wilfred Sellars and Robert Brandom. HAUGELAND, supra. The second and third constructions overlap with social construction theory. See IAN HACKING, THE Social Construction of What? (1999); J.R. SEarle, THE CONSTRUCTION OF SOCIAL REALITY (1995); PETER L. Berger \& THOMAs LuCKMANN, THE SOCIAL. CONSTRUCTION OF REALITY (1966). Searle's and Austin's theory of speech acts is a third framework that is conceptually related to these two. See J.L. AUSTIN, How To Do THINGS WITH WORDS ( $2 \mathrm{~d}$ ed. 1975); JOHN R. SEARLE, SPEECH ACTS: AN ESSAY ON THE PHILOSOPHY OF LANGUAGE (1969) (distinguishing "propositional" from "performative" speech-utterances that do things rather than assert things).

Nominalism can be contrasted with (Frege-Russell) descriptivism, according to which a name refers to an object by virtue of the name being associated with a description that the object in turn satisfies. $C f$. Frederick Schauer, Formalism, 97 YALE L.J. 509, 530-31 \& n.85 (1988) (considering the possibility that language taken alone may itself be authoritative). Schauer distinguishes the category to which a rule applies (i.e., the predicate facts) from the consequences following from the existence of those facts or application of the rule. Id. at $534 \mathrm{n} .78$ (citing W. TwINING \& D. MIERS, How To Do THINGS WITH RulEs 136-40 (2d ed. 1982); see also Sherwin, supra note 4 (advocating the adoption of relatively hard-edged rules in formulating relatively determinate forms of property, adopting Schauer's notion of "semantic autonomy," as opposed to relying on contextual and perhaps discretionary "standards" based determination). As the discussion in Part VI infra suggests, contextual decision-making is not necessarily inconsistent with durable thingness.

154 Levi-Strauss's materialist turn-of-the-century sociology remains conceptually vigorous. See, e.g., JEAN BAUDRILlaRD, THE CONSUMER SOCIETY: MYTHS AND STRUCTURES (George Ritzer trans., 1998) (1970) (adapting and abstracting Levi-Strauss with respect to signs); MARSHALl SAHLINS, CULTURE AND PRACTICAL REASON 176-78 (1976).

155 See Herbert SimON, THE SCIENCES OF THE ARTIFICIAL (3d ed. 1996).

156 See leo MarX, The Machine IN the Garden: TeChNOlogy and the Pastoral IDEAL IN AMERICA (1964). Marx described contradictions in American culture that required the persistence of an older, pastoral idea alongside a technologically-driven society that largely conceals its mechanistic, ordered, even inevitable reality from those participating in it, the artificial and the industrial, and the natural and the pastoral, becoming one contradictory whole. He argued that American culture has strived, often without success, to meld modern machine 
cial character of twentieth century culture, particularly American culture, and on the modern American instinct to naturalize that culture, to make it appear as though what we have created were in fact merely a natural result. ${ }^{157}$

The impact of the thing-by-design argument can be seen in a variety of places in the law. We may regulate designed things on the basis of demonstrated health or safety concerns, ${ }^{158}$ but difficulties with regulating the details of designs of manufactured food and pharmaceutical products, for example, and even of obviously dangerous objects like handguns, are well known. ${ }^{159}$ In antitrust law, generally a manufacturer has no duty to make its product interoperable with products of any other firms. ${ }^{160}$ More (or perhaps less) pedestrian ex-

technology and the perfectability and divinity of the natural world. See also DAVID E. NYE, AMERICA AS SECOND CREATION: TECHNOLOGY AND NARRATIVES OF NEW BEGINNINGS (2003); DAVID E. NYE, AMERICAN TECHNOLOGICAL SuBlime (1996). For a more optimistic view of the mapping of the artificial to the natural, with naturalized machines as a source of intelligence rather than of oppression, see GEORGE B. Dyson, DARWIN AMONG THE MACHINES: ThE EVOLUTION OF GLOBAL INTELLIGENCE (1997).

157 See MARX, supra note 156, at 277-319. One might say that creators' and designers' discretion facilitates the naturalization of things, a process that reinforces their authority. The limited functionality of a DRM-enabled electronic book may seem acceptable-may be acceptable, in a cultural and/or legal sense-because it just comes that way. If you get to make the thing, you get to design the thing. If you get to design the thing, you get to design the law. What matters is not whether the words constitute the thing, see supra note 153, or the thing constitutes the words; what matters is the source of the relationship. On the transformative potential of things, see Bruno Latour, The Berlin Key or How To Do Words with Things (1993), in MATTER, MATERIALITY AND MODERN CULTURE 10 (P.M. Graves-Brown ed., 2000).

158 See, e.g., Castrignano v. E.R. Squibb \& Sons, Inc., 546 A.2d 775 (R.I. 1988) (addressing, under comment $k$ to section $402 \mathrm{~A}$ of the Restatement (Second) of Torts, the strict liability of product sellers, providing that sellers of unavoidably unsafe products are not strictly liable for harm, provided they are accompanied by proper directions and warning).

${ }_{159}$ The law of products liability is premised in part on what might be called a duty of safe design. See RESTATEMENT (SECOND) OF TORTS § 402A (1965). In many cases, however, courts have blended the questions of the manufacturer's dangerous design and its failure to provide an adequate waming, leading to what some view as inappropriate deference to design decisions. See David G. Owen, The Puzzle of Comment j, 55 HASTINGS L.J. 1377 (2004).

160 See C.R. Bard, Inc. v. M3 Sys., Inc., 157 F.3d 1340, 1372 (Fed. Cir. 1998) (Newman, J., dissenting in part):

It is without precedent to find antitrust liability premised on a theory that development of new products is illegally anticompetitive when the new product requires competing suppliers to adjust their product accordingly. Commentators who have considered the question of "whether product innovation can ever be unlawfully "predatory"" have concluded that "no administrative rule could be fashioned that would not exact an unreasonably heavy toll."

3 PHILlIP E. AREEDA \& HERBERT HOVENKAMP, ANTITRUST LAW \$ 705b (rev. ed. 1996); see also United States v. Microsoft Corp., 147 F.3d 935, 948 (D.C. Cir. 1998) (expressing skepticism over court supervision of product design); Medtronic Minimed Inc. v. Smiths Med. MD Inc., 371 F. Supp. 2d 578 (D. Del. 2005) (distinguishing C.R. Bard and holding manufacturer not liable for attempted monopolization where change to design of its infusion set connector system made it impossible for competitor to sell infusion sets).

This is a corollary of the principle that in general there is neither antitrust liability nor li- 
amples drive the argument to its conclusion. Film producers can no more be ordered to deliver copies of movies on multiplatform (or nondecaying) DVDs than authors and publishers can be required to use high quality paper. Whether something lasts or decays, or whether it works efficiently, or whether it optimizes social welfare, can be regulated only at the farthest margins.

To be clear, whether because of its abiding respect for personal autonomy or because the effects of autonomous design decisions are recharacterized as "natural" outcomes, law expresses a strong reluctance to interfere with good-faith decisions concerning the design of things. Copyright law authorizes copyright protection for works of authorship "fixed" in a tangible medium of expression "by or under the authority of the author." ${ }^{\prime 161}$ In Sony Corp. of America v. Universal Studios, ${ }^{162}$ holding that manufacturers of videocassette recorders are not liable for infringement by their users, the Supreme Court majority affirmed the presumptive design right afforded the technological innovator. ${ }^{163}$ A VCR could be used to infringe, but the Court would not order that it be designed otherwise. That principle has been affirmed

ability under intellectual property law for unilateral refusals to deal or to license with respect to intellectual property rights. See 35 U.S.C. $\$ 271(d)(4)(2000)$ (prohibiting liability for misuse for failure to use or license the patent); $I n$ re Indep. Serv. Org. Antitrust Litig., 203 F.3d 1322 (Fed. Cir. 2000) (Xerox); Miller Insituform v. Insituform of N. Am., 830 F.2d 606 (6th Cir. 1986) (holding there was no antitrust violation for exclusive patent licensee to terminate sublicense and enter the market itself); Hartford-Empire Co. v. United States, 323 U.S. 386, $432-33$ (1945) (holding that patentee has no obligation to use or license the patented invention). Antitrust law has a difficult time distinguishing (presumptively valid) unilateral refusals to deal from invalid concerted (i.e., contractual) restrictions. The issue comes to a head in tying cases, with conditional refusals to deal. There is a distinction, reaffirmed in Xerox, between simple unilateral refusals to deal and conditional (but not contractual) refusals to deal that have the same economic effects as contractual refusals, such as tying. The distinction is not perfectly clear, but there are some limits to the right to impose conditions on buyers. See infra notes 187-204 and accompanying text (describing evolution of law on restrictive notices). Compare United States v. Colgate \& Co., 250 U.S. 300 (1919) (concluding that manufacturer that refuses to deal with buyers who refuse to follow prices set by manufacturer does not engage in illegal price fixing), with Monsanto Co. v. Spray-Rite Corp., 465 U.S. 752 (1984) (holding that agreement to set resale prices constitutes illegal vertical price restraint). See also Serv. \& Training Inc. v. Data Gen., 963 F.2d 680 (4th Cir. 1992) (holding software company's refusal to license diagnostic software except to end-user customers acceptable as unilateral and not a de facto tying arrangement).

16117 U.S.C. $\$ 101$ (2000) (defining "fixed"); 17 U.S.C. $\S 102(a)$ (2000) (explaining that copyright subsists in works fixed in tangible medium of expression); see also 17 U.S.C. $\$ 1101$ (2000) (imposing liability for unauthorized fixation of live musical performance).

162464 U.S. 417 (1984).

163 See Mark A. Lemley \& R. Anthony Reese, Reducing Digital Copyright Infringement Without Restricting Innovation, 56 STAN. L. REV. 1345, 1355-56 (2004). The one particularly notable exception in copyright law is the Audio Home Recording Act of 1992, codified at 17 U.S.C. $\$ \S 1001-1010$ (2000), which not only regulates the design of things (in this case, digital audio recording technology) in precise ways, but mandates that designers incorporate certain functions into their designs. 
in the Internet context, as applied to peer-to-peer (P2P) file sharing software. Courts that have rejected the design right have done so in cases where the designer's good faith was not merely open to question, but was clearly absent. ${ }^{164}$ A similar analysis pervades the decision in United States v. Microsoft Corp. ${ }^{165}$ holding that Microsoft was not liable under American antitrust law for allegedly designing its Windows operating system software so as to disadvantage a rival Web browser. ${ }^{166}$ In the framework of this Article, thing-as-design presumptively treats the "thing" as what the creator, inventor, designer, or manufacturer says that it is. ${ }^{167}$

The best-established legal doctrine that follows this model-that a thing is a thing and is a specific sort of thing because the producer says so-lies in the area of computer software. The common law of property distinguished real property from chattels, and chattels real (connected to realty) from chattels personal (everything that was not realty or connected to realty). Blackstone could hardly have anticipated Babbage, let alone contemporary computer programs. Nonetheless, as the law has come to characterize a "computer program" as a patentable and copyrightable thing, it has also come to accept the proposition that a computer program is a distinct but different kind of chattel or "thing." Computer programs are licensable things. The law recognizes programs as chattels partly by default (a computer program is presumed to be the subject of property interests, and it is not

164 See Metro-Goldwyn-Mayer Studios, Inc. v. Grokster, Ltd., 125 S. Ct. 2764 (2005). I read the Court's opinion in Grokster, which confirmed the existence of a tort known as "inducing" copyright infringement, as preserving the basic principle described in the text. Mere design of a product capable of infringing use would not support liability; design coupled with additional evidence of intent to encourage copyright infringement would defeat the premise that the design was undertaken in good faith. See id. at $2781 \mathrm{n} .12$; see also In re Aimster Copyright Litig., 334 F.3d 643, 653 (7th Cir. 2003) (noting that the defendant distributed file sharing technology in full awareness of its use for infringement and with no credible belief as to its noninfringing use); A\&M Records, Inc. v. Napster, Inc., 239 F.3d 1004, 1020 (9th Cir. 2001) (same).

165 253 F.3d 34 (D.C. Cir. 2001).

160 Id. at 83-84. European regulators have been less deferential. See Commission of the European Communities, Commission Decision of 24.03 .04 relating to a proceeding under Article 82 of the EC Treaty (Case COMP/C-3/37.792 Microsoft), 2004 (C900), available at http://europa.eu.int/comm/competition/antitrust/cases/decisions/37792/en.pdf [hereinafter Commission Decision of 24.03.2004] (finding Microsoft liable under European antitrust law for bundling operating system and media player technology); see also infra notes 396-405 and accompanying text (discussing the Microsoft case as a question of thing-by-policy).

167 In many instances, the designs "speak" for themselves, that is, the law chooses not to regulate the design or to regulate only lightly. In others, express and implied narratives of creation are given priority over claims of competing users or regulators. Arguments in support of a right to make and control cultural meanings often have a critical dimension. See Chander, supra note 36, at 797; Madhavi Sunder, Cultural Dissent, 54 STAN. L. REv. 495 (2001). But they need not. Trademark law validates the efforts of commercial producers to use signs to define the properties of things. Trademark law can be construed as guarding against attempts to disrupt an ontology (the mark itself) that is presumptively established via the efforts of the market owner. 
connected to real property), but it has recognized their licensable character largely by accepting the assertions of software developers that this is so. ${ }^{168}$

The effectiveness of thing-by-design in software licensing is based largely on the absence of any compelling theoretical justification for the maxim that purports to prohibit equitable servitudes on chattels. ${ }^{169}$ We know, because Zechariah Chafee reminded us, ${ }^{170}$ that chattels cannot be the subjects of servitudes, that is, obligations regarding use of the object that bind not only parties in privity with the originator of the servitude but any party that encounters the object with adequate notice of the obligation. Objects can be the subjects of agreements not to use them for certain purposes, but enforcement of those agreements will be limited by principles of unfair competition and antitrust law. Mere servitudes, unilateral in origin, typically are treated differently and typically are regarded as unenforceable.

168 See, e.g., Adobe Sys. Inc. v. One Stop Micro, Inc., 84 F. Supp. 2d 1086, $1091-92$ (N.D. Cal. 2000) (accepting and relying on testimony of software licensor's expert witness regarding universality of software licensing). The few cases that reject software licensors' attempts to enforce license terms, such as Softman Products Co. v. Adobe Systems, Inc., 171 F. Supp. 2d 1075, 1083 (C.D. Cal. 2001), rely on uncommon fact patterns or otherwise do not reflect the sheer uniformity of legal and commercial practice on this point. Where industry practice does not turn an ownable thing into a licensable thing, a particular licensor may do so by repeating the license mantra frequently enough. See, e.g., Register.com, Inc. v. Verio, Inc., 356 F.3d 393 (2d Cir. 2004) (enforcing license restriction on access to electronic database); M.A. Mortenson Co. v. Timberline Software Corp., 998 P.2d 305 (Wash. 2000) (enforcing license restriction on computer program).

169 The leading American case, RCA Manufacturing Co. $v$. Whiteman, 114 F.2d 86 (2d Cir. 1940) (Hand, J.), relies on an antimonopoly sense that clearly echoes Coke. See COKE, supra note 103; see also Bus. Elec. Corp. v. Sharp Elec. Corp., 485 U.S. 717, 733 (1988) (citing Boston Store of Chi. v. Am. Gramophone Co., 246 U.S. 8, $21-22$ (1918)); Dr. Miles Med. Co. v. John D. Park \& Sons Co., 220 U.S. 373, 404 (1911) (invoking Coke explicitly in the antitrust context). Software licenses have provoked a growing literature designed to fill precisely the gap described in the text. See, e.g., Bjerre, supra note 81 (describing the conceptual problem in terms of whether a later creditor who takes a security interest in the previously encumbered property knows what the thing is that is offered as security, updating the maxim, Nemo dat quod non habet, or "No one may give what he does not have," and advocating a solution based on cognitive modeling); Jacqueline Lipton, The Law of Unintended Consequences: The Digital Millennium Copyright Act and Interoperability, 62 WASH. \& LEE L. REV. 487 (2005) (arguing that products with embedded computer software should not be protected under the DMCA); Robinson, supra note 38 (urging the enforceability of servitudes, based on the inability to distinguish between tangible and digital objects); John A. Rothchild, The Incredible Shrinking First-Sale Rule: Are Software Resale Limits Lawful?, 57 RUTGERS L. REV. 1 (2004) (concluding that resale restrictions should be unenforceable); Stewart E. Sterk, What's in a Name? The Troublesome Analogies Between Real and Intellectual Property (Cardozo Law, Legal Studies Research Paper No. 88, 2004), available at http://papers.ssrn.com/abstract=575121 (drawing distinctions between real and personal property for purposes of analyzing servitudes); Molly S. Van Houweling, Copyright Servitudes 5-10 (2005) (unpublished manuscript, on file with author) (articulating policy justifications for anti-servitude presumption).

170 See Zechariah Chafee, Jr., Equitable Servitudes on Chattels, 41 HARV. L. REV. 945 (1928). 
Computer programs, however, can be copyrighted. Copyrights (which are conceptual things) can be licensed. And over a relatively short period, the practice of licensing computer programs-the objects, not merely the copyrights-has become both standardized and legitimated under law. Use of computer programs is tightly regulated by license terms, often in ways that are far more restrictive than copyright law often would permit by default. ${ }^{171}$ Licensing software is acceptable, courts imply, because licensing copyrights is acceptable. ${ }^{172}$ Both in language and function, the license controls the program, not the copyright.

The law, in other words, treats the relevant "thing," not as the program itself in its designed or engineered form, but as the "licensed program."173 The practice of software developers is to license programs. The source of the practice is declarations by software developers that as the creators of these products, they are entitled to give the programs shape, including their legal shape. By accepting that shape as a legitimate legal form, the law has created the thing - the licensed program. $^{174}$

171 See Bowers v. Baystate Techs., Inc., 320 F.3d 1317 (Fed. Cir. 2003) (enforcing license prohibition on reverse engineering of computer software).

172 The transition from licensing the copyright to licensing the code may be an example of what sociologists refer to as institutional isomorphism, or a tendency toward homogenization among institutions and organizations in a given field. The analytic issue becomes legitimacy of the form, rather than its efficiency or effectiveness, since the pattem of organization and process that drives homogenization is not driven by efficiency considerations. See Roger Friedland \& Robert R. Alford, Bringing Society Back In: Symbols, Practices, and Institutional Contradictions, in THE NEW INSTITUTIONALISM IN ORganizational ANALYSIS 232, 242-47 (Walter W. Powell \& Paul J. DiMaggio eds., 1991); Paul J. DiMaggio \& Walter W. Powell, The Iron Cage Revisited: Institutional Isomorphism and Collective Rationality, in THE NEW INSTITUTIONALISM IN ORGANIZATIONAL ANALYSIS, supra, at 41. For an overview of arguments for and against the legitimacy of the license form, see Michael J. Madison, Reconstructing the Software License, 35 LOY. U. CHI. L.J. 275 (2003).

${ }_{173}$ E.g., Davidson \& Assocs. v. Internet Gateway Inc., 334 F. Supp. 2d 1164, 1177 (E.D. Mo. 2004), aff'd sub nom. Davidson \& Assocs. v. Jung, 422 F.3d 630 (8th Cir. 2005) (concluding that the first sale doctrine did not apply to transactions in computer program because the users did not buy the software; instead, they bought a license to the software). Proponents of proposed Article 2B of the Uniform Commercial Code, later the proposed Uniform Commercial Information Transactions Act (UCITA), took to supporting their arguments for adoption with the mantra that "the [software] license is the product," as a way of arguing that both economically and legally, the program and its license terms were indistinguishable. See Robert W. Gomulkiewicz, The License Is the Product: Comments on the Promise of Article $2 B$ for Software and Information Licensing, 13 BERKELEY TECH. L.J. 891 (1998); cf. Raymond T. Nimmer, Licensing in the Contemporary Information Economy, 8 WASH. U. J.L. \& POL'Y 99, 129 (2002) ("[A]n authorized sale of a copy [of a copyrighted work] is best viewed as a form of license.").

174 This may be the easiest way to justify application of Article 2 of the Uniform Commercial Code to transactions in software. See, e.g., Arbitron, Inc. v. Tralyn Broad., Inc., 400 F.3d $130,138 \mathrm{n} .2(2 \mathrm{~d} \mathrm{Cir} .2005)$ (recognizing a lack of clarity in the case law regarding the application of Article 2 to software licenses); Specht v. Netscape Commc'ns Corp., 306 F.3d 17, 29 n.13 (2d Cir. 2002) (noting potential application of Article 2 to software download transaction). "Progam-as-licensed-thing" may also be the best way to appreciate the proposed scope of 
Designers press further. The decomposability of the digital object means that the program and the digital file can be disaggregated and reaggregated into apparently endless, licensable sub-"things." This is so not despite the physical reality that the hallmark of the digital world appears to be the absence of conventional, stable "thingness," but because of it. Like the broomsticks of the Sorcerer's Apprentice, the digital descendants of a given computer program are automatically burdened with the same "licensed" character that the designer imposes upon the parent. This is most obviously and purposefully the case with respect to licenses for open source computer software, which have been aptly characterized as "covenants that run with the code."175

The apparent legitimacy of the license for software justifies its extension in a number of directions, under the cloak of thing-as-design. The functional equivalence of software licenses and technological limitations on access to and use of digital products yields legal validation of Digital Rights Management (DRM) technology. Technological DRM-based "access" and "copy" controls linked to digital content by authors and distributors are privileged under the Digital Millennium Copyright Act (DMCA) from interference by competitors and consumers, ${ }^{176}$ so long as the technical measure in question "in the ordinary course of its operation, requires the application of information, or a process or a treatment, with the authority of the copyright owner, to gain access to the work." 177 As a practical matter, the DMCA encourages content owners simply to design digital versions of their products so that DRM controls are inextricably intertwined with the underlying work. The result is the DVD that can be played only on an "authorized" DVD player or disk drive; ${ }^{178}$ the eBook that can be viewed only on an "authorized" eBook reader; ${ }^{179}$ and the computer printer that functions only with an ink cartridge supplied by the printer manufacturer. ${ }^{180}$ DRM in combination with the underlying

UCITA, which authorized licenses of "information." See Uniform Computer Information Transactions Act $\S 102(a)(35)(2000)$ (defining "information" as "data, text, images, sounds, mask works, or computer programs, including collections and compilations of them").

175 David W. Operbeck, The Penguin's Genome, or Coase and Open Source Biotechnology, 18 HARV. J.L. \& TECH. 167, 182 (2004); see Margaret Jane Radin, Humans, Computers, and Binding Commitment, 75 IND. L.J. 1125,1132 (1999) (proposing the term "viral contracting" for the "attempt to make commitments run with a digital object").

176 See 17 U.S.C. $\$ \$ 1201-1205$ (2000).

177 Id. $\$ 1201$ (a)(3)(B) (2000). This definition applies to "access controls." A comparable definition applies to "rights controls." See id. § 1201(b)(2)(B) (2000).

178 See Universal City Studios, Inc. v. Corley, 273 F.3d 429 (2d Cir. 2001).

179 See United States v. Elcom Ltd., 203 F. Supp. 2d 1111 (N.D. Cal. 2002).

180 See Lexmark Int'l, Inc. v. Static Control Components, Inc., 387 F.3d 522 (6th Cir. 
work results in a single new thing, rather than in two distinct things. ${ }^{181}$ The behavioral "law" that results from these combinations-the DVD that will not play on nonvalidated machines-has been matched in most cases by formal endorsement of these arrangements under the DMCA, and then by courts. As the software developer declares that its software comes only in licensed form, the digital content producer is presumptively entitled to design that content in a technological wrapper and forcibly prevent consumers from unwrapping that content without permission. DRM validated by the DMCA represents the legal priority of the designers' discretion: the legitimate restricted-use thing.

Following this reliance on the temporal priority of the designer, there is little reason for the law's continued adherence to the common law principle that forbids equitable servitudes on chattels generally. Glen Robinson, in a recent article, proposes precisely this move. ${ }^{182}$ It is a short step from this proposition to the counterpart principle that equivalent discretion should be respected when use restrictions are simply designed into the artifact. Both cases share the presumption that "first owners" determine what the thing is, whether by engineering decisions, or by legal prescriptions. Robinson's argument works equally effectively in reverse. Given our relative inability to regulate product design, there is no more compelling reason to regulate servitudes, which are the functional (and often cheaper) equivalent of design. ${ }^{183} \mathrm{~A}$ limitation on use that arises from the nature of the thing (it decays with use, for example, and physically cannot be reused) can be represented and enforced via notice of the limitation. A manufacturer might produce a single-use camera that physically decays after one use, or that might be reused but for a "single-use only" legend on its housing. There may be no principled basis for distinguishing one from the other, if, as Robinson argues, the problem compounds questions of regulatory competence and baselines. Rejecting the Aristote-

2005).

181 By using this precise argument, technology vendors deny claims that they are acting anticompetitively by engaging in unlawful tying or misuse of intellectual property interests. See Dan L. Burk, Anticircumvention Misuse, 50 UCLA L. REv. 1095, 1134-35 (2003); Michael A. Einhorn, Digitization and Its Discontents: Digital Rights Management, Access Protection, and Free Markets, 51 J. COPYRIGHT SOC'Y U.S. 279, 305-06 (2004).

182 Robinson, supra note 38 , at 1462 (" $[1]$ t isn't easy to explain why the second owner's right to unburdened use of property should trump the first owner's rights to burden the property. It also isn't easy to see why that explanation, whatever it is, should be any different for real and personal property.").

183 See id. at 1519-21 (discussing the Microsoft antitrust litigation). 
lian approach, the designer's approach—whether via engineering, or via notice-must do.

So understood, the law and practice of software licensing is less unique, and it draws support from examples of "limited use" labeling and restrictive notices from other corners of the law. Recent patent cases from the Federal Circuit have enforced "single-use only" label restrictions against defendants who found ways to recondition, remanufacture, or resell patented things, ${ }^{184}$ notably in Mallinckrodt, Inc. v. Medipart, Inc. ${ }^{185}$ Some, but not all, of these cases have been framed as claims for breach of contract (the purchaser "assenting" to an "offer" stated on a package), but in all of them the court has pointed out the role of notice as a key element in binding the user. ${ }^{186}$ In function, however, the "contract" formed in these cases has borne the same tenuous relationship to the paradigmatic bargain -or even to a paradigmatic form-based transaction-that characterizes the typical shrink-wrap license for computer software. It is not possible to use the product yet not "assent." The restriction is legally designed into the product itself.

This form of thing-by-design has a long pedigree. In a series of cases in the later nineteenth century, the American Cotton-Tie Supply Company obtained injunctions against reuse of buckles used in a patented combination to bind bales of cotton and which were reused on multiple bales. ${ }^{187}$ The company had stamped a single-use only restriction on each buckle, leading to the possible conclusion, given the Supreme Court's ruling in favor of the company in American Cotton-Tie Co. v. Simmons, ${ }^{188}$ that the restriction constituted an enforceable servitude in patent law. ${ }^{189}$ As antitrust and unfair

184 See Monsanto Co. v. McFarling, 363 F.3d 1336 (Fed. Cir. 2004); Bowers v. Baystate Techs., Inc., 320 F.3d 1317 (Fed. Cir. 2003); Mallinckrodt, Inc. v. Medipart, Inc., 976 F.2d 700 (Fed. Cir. 1992); see also B. Braun Med., Inc. v. Abbott Labs, 124 F.3d 1419 (Fed. Cir. 1997) (holding that post-sale restrictions on the use of a patented device are valid if they are contractual in character).

185 Mallinckrodt involved a claim for inducing infringement against a defendant who allegedly induced reuse of a patented medical device labeled "single use only." Mallinckrodt, 976 F.2d at 702 .

186 See Jazz Photo Corp. v. Dynatec, 264 F.3d 1094 (Fed. Cir. 2003) (finding no implied license limiting use of "single use" camera to one use, where there was no evidence that defendant had agreed to "single use" limitation).

187 American Cotton-Tie Supply Co. v. Bullard, 1 F. Cas. 625 (C.C.S.D.N.Y. 1879) (No. 294) (reviewing cases, and granting injunction).

188106 U.S. 89 (1882).

189 Because the buckles were not themselves patented but were combined with straps to form the patented combination, reuse of the buckles implicated the line between exhaustion of the patent right and reconstruction of the patented article. Not all of the early cases approving restrictive notices, however, ran up against that problem. See Henry v. A.B. Dick Co., 224 U.S. 1 (1912); Heaton-Peninsular Button-Fastener Co. v. Eureka Specialty Co., 77 F. 288 (6th Cir. 1896). 
competition concerns took hold at the Court shortly afterward, opinions in the several decades following American Cotton-Tie were decidedly hostile to restrictive notices. Bobbs-Merrill Co. v. Straus, ${ }^{190}$ generally regarded as the modern foundation of the first sale doctrine in copyright, refused to enforce a notice fixing resale prices that appeared on the inside cover of a book. The Court distinguished American Cotton-Tie and downplayed the significance of the notice in the context of that case. Restrictive notices attached to motion picture projectors and phonographs, purporting to limit their use to film and content produced by the same or related manufacturers, were struck down as being "beyond the patent grant," that is, as purporting to redefine the thing conveyed, though we would recognize them today as arguably anticompetitive. ${ }^{191}$

Through the middle part of the twentieth century, the Court's record regarding restrictive notices was mixed, as it sometimes favored antitrust considerations (discounting thing-by-design) ${ }^{192}$ and sometimes favored patent law considerations (supported by thing-bydesign). ${ }^{193}$ In General Talking Pictures Corp. v. Western Electric, ${ }^{194}$ the Court affirmed a finding of patent infringement where the patentee had used a notice that limited the patented motion picture projectors to amateur use, though it was not clear whether the limited use notice was itself the basis for the Court's holding. Although General Talking Pictures has been implicitly questioned, ${ }^{195}$ it has not been

190210 U.S. 339 (1908).

191 See Boston Store of Chi. v. Am. Graphophone Co., 246 U.S. 8 (1918) (finding reseller of patented "sound recording machines" not bound by "license notice" on machines affixed by patentee ("licensing" the machine and requiring use only with sound boxes and needles made by patentee), despite actual notice, since it was transparently a price fixing scheme); Motion Picture Patents Co. v. Universal Film Mfg. Co., 243 U.S. 502 (1917) (same); Straus v. Victor Talking Mach. Co., 243 U.S. 490 (1917) (same); Bauer \& Cie v. O'Donnell, 229 U.S. 1, 17 (1913) (rejecting restrictive notices as to price as not enforceable because they were "beyond the limits of the monopoly secured by the patent act"); $c f$. Gen. Elec. Co. v. Cont'l Lamp Works, $280 \mathrm{~F}$. 846 (2d Cir. 1922) (holding notice on unpatented lamp base sold by patentee effective to bar use of base by purchaser in manufacturing lamp patented by same patentee, where bases had noninfringing uses, and purchaser knew of the notice at the time of purchase). The "not within the patent grant" reasoning was criticized harshly by William Baxter: "A promise by the licensee to murder the patentee's mother-in-law is as much 'within the patent monopoly' as is the sum $\$ 50.00$; and it is not the patent laws which tell us that the former agreement is unenforceable and subjects the parties to criminal sanctions." William F. Baxter, Legal Restrictions on Exploitation of the Patent Monopoly: An Economic Analysis, 76 Y ALE L.J. 267, 277 (1966).

192 See United States v. Univis Lens Co., 316 U.S. 241 (1942) (rejecting the ostensible "license" character of transaction by which finisher of patented lens blanks acquired the blanks, and holding that it was free to distribute the resulting eyeglasses).

${ }^{193}$ See United States v. Gen. Elec. Co., 272 U.S. 476 (1926) (upholding resale price restrictions imposed via a manufacturing license rather than notice).

194304 U.S. 175 (1938), aff'd on reh'g, 305 U.S. 124 (1938).

195 See Automatic Radio Mfg. Co. v. Hazeltine Research, Inc., 176 F.2d 799 (1st Cir. 1949) (affirming judgment for patentee against manufacturer that unilaterally discontinued affixing limited use notices to patented goods, as required by manufacturing license), aff' $d, 339$ 
overruled, and the Federal Circuit relied on it extensively, along with American Cotton-Tie, in Mallinckrodt ${ }^{196}$ Aro Manufacturing Co. $v$. Convertible Top Replacement Co. (Aro I), ${ }^{197}$ in the course of determining that repair of the fabric of a convertible top did not infringe a patent in the top, appeared to revive the idea of restrictive notices when it distinguished American Cotton-Tie on the ground that the Court had treated the restrictive notice as significant. ${ }^{198}$ Though Aro I is otherwise conceptually based on the notion that the repairing defendant did not produce the essence of the "thing" patented, its apparent endorsement of the notice-basis of American Cotton-Tie gaveand gives-support to a thing-by-design rule.

More recent cases, then, work outward from Aro I and General Talking Pictures, drawing not only on restrictive notice cases but also on questions of exhaustion of the patentee's interests upon sale of the patented product, and on the line between repair and reconstruction of the patented thing. ${ }^{199}$ Exhaustion and repair and reconstruction cases depend in part on a premise that sale of a patented item includes an implied license to practice the invention and to repair the item. ${ }^{200} \mathrm{~A}$ natural corollary of that premise permits patentees unilaterally and expressly to negate such a license-via language as well as by design. ${ }^{201}$ The Federal Circuit drew precisely this connection in Mal-

\section{U.S. 827 (1950).}

196 Mallinckrodt, Inc. v. Medipart, Inc., 976 F.2d 700, $705-07$ (Fed. Cir. 1997).

197365 U.S. 336 (1961).

198 Id. at 343 n.9. One appellate court, writing shortly after Aro I, expressed doubt as to the enforceability of a restrictive notice. Fromberg, Inc. v. Gross Mfg. Co., 328 F.2d 803, 809 (9th Cir. 1964). On the other hand, the Court of Claims, in General Electric Co. v. United States, 572 F.2d 745, 784-85 (Ct. Cl. 1978), referred to American Cotton-Tie and Aro I as supporting the viability of conditions imposed on the sale of patented goods.

${ }_{199}$ They have been criticized richly as a result. See supra note 124, at 30-35 (criticizing Mallinckrodt as inconsistent with doctrine of exhaustion).

200 See, e.g., Carborundum Co. v. Molten Metal Equip., 72 F.3d 872 (Fed. Cir. 1995) (holding that purchasers of unpatented but custom-designed pump from patentee did not receive implied license to practice the invention, where the pump could be used only in the patented process).

201 De Forest Radio Tel. Co. v. United States, 273 U.S. 236 (1927) (holding that an implied license in favor of one who uses an invention may arise from an equitable estoppel); Wang Labs., Inc. v. Mitsubishi Elecs. Am., Inc., 103 F.3d 1571, 1578-82 (Fed. Cir. 1997) (noting that an implied license may arise from an estoppel or otherwise from the patentee's statements or conduct). A comparable problem arises in the context of copyright law. See Nimmer, supra note 173 (characterizing authorized sale of a copy of a copyrighted work as encompassing an implied license to distribute that copy). A license to reproduce a copyrighted work may be inferred from the circumstances surrounding delivery of the work, see Effects Assocs., Inc. v. Cohen, 908 F.2d 555 (9th Cir. 1990), but the copyright owner may characterize those circumstances as an express license and thus limit the scope of the user's rights. Cf. 17 U.S.C. $\$ 117$ (2000) (describing scope of rights of owner of a computer program); DSC Commc'ns Corp. v. Pulse Commc'ns, Inc., 170 F.3d 1354 (Fed. Cir. 1999) (holding that telephone companies were not "owners" of software within the meaning of $\S 117$, given acquisition of program under a license 
linckrodt. Even though the court specified that the restriction had a contractual character, it noted that the patentee could choose to sue in contract or in patent. ${ }^{202}$ Related corollaries include the notion that if the patentee's intent matters most, then that intent might encompass control over reuse of the patented item, ${ }^{203}$ and the specification that intent is manifested at the time the item is delivered to the consumer, and not later. Whether there is assent or not, notice-that is, designmatters. ${ }^{204}$

Analytically identical situations arise in a variety of contexts, including genetically engineered seeds, ${ }^{205}$ technical standards for computer and broadcast networks critiqued as "architecture,"206 and first sale and exhaustion problems in trademark law. These last problems, as defenses to a claim of infringement by a trademark owner against a reseller or reconditioner of the marked good, are cousins of similar questions in copyright and patent. As with trademark questions generally, however, they are framed less in terms of the identity of the thing resold or reconditioned and more in terms of the relationship

agreement).

${ }^{202}$ Mallinckrodt, Inc., v. Medipart, Inc., 976 F.2d 700, 707 n.6 (Fed. Cir. 1997)

${ }^{203}$ See Kendall Co. v. Progressive Med. Tech., 85 F.3d 1570 (Fed. Cir. 1996) (finding that a "single use only" limitation on patented compression device manifested patentee's awareness that users would buy replacement sleeves even before they wore out).

${ }^{204}$ See Met-Coil Sys. v. Korners Unlimited, 803 F.2d 684 (Fed. Cir. 1986) (finding that customers who purchased patented roll-forming machine received an implied license to use the machine where patentee/seller failed to include notice with sale negating presence of implied license). In light of Bowers, it is not clear whether the Federal Circuit would adhere to a substantive notice requirement today. Other courts, in cases involving related subject matter, have solved the notice problem in creative ways. See, e.g., Register.com, Inc. v. Verio, Inc., 356 F.3d 393 ( $2 \mathrm{~d}$ Cir. 2004) (finding collector of electronic data from Internet database bound by electronic notice given to computer program).

For a pointed critique of notice-based liability for unauthorized reuse of things, see Jean Braucher, Amended Article 2 and the Decision To Trust the Courts: The Case Against Enforcing Delayed Mass-Market Terms, Especially for Software, 2004 WISC. L. REV. 753, 769-72 (distinguishing warranties that accompany products on the ground that they originate with the tort regime, rather than with a contract or property model, and therefore do not depend on notice or assent by the consumer).

205 See Dan L. Burk, DNA Rules: Legal Implications of Biological "Lock-out" Systems, 92 CAL. L. REv. 1553, 1557-60 (2004); J.E.M. AG Supply, Inc. v. Pioneer Hi-Bred Int'l, Inc., 534 U.S. 124 (2001) (affirming judgment of infringement of patented seed technology where defendant violated terms of limited label license).

${ }^{206}$ Lawrence Lessig popularized the "architectural" analogy in the context of his argument that legal regulation might be designed into technical standards. See LESSIG, supra note 71 . A recent controversy, involving a Federal Communication Commission mandate that digital television signals incorporate a so-called broadcast flag in order to deter their unauthorized redistribution, shows that the normative implications of the analogy are far from clear. Compare Randal C. Picker, From Edison to the Broadcast Flag: Mechanisms of Consent and Refusal and the Propertization of Copyright, 70 U. CHI. L. REv. 281, 291-93 (2003) (suggesting virtues of embedded control technology), with Crawford, supra note 46 (arguing that embedded technology interferes with evolutionary processes connected with creativity). 
between the reseller and the thing. An authorized sale of the marked good exhausts the mark owner's rights in that good. Unlike patent law, under which a reconditioned item can be lawfully resold so long as the resold item is not the "patented item" itself, trademark law grants to the mark owner the presumptive right to say what the thing is-that is, "an object produced by a certain firm"—on resale as well as on initial sale. Resale of marked goods in their original packaging is permitted. ${ }^{207}$ Sale of refurbished goods is likewise acceptable so long as they are sold as such, and not as originals. ${ }^{208}$ Repackaging of original goods under the original mark is also acceptable, so long as the reseller informs consumers that it has done the repackaging. ${ }^{209}$ Modifying the packaging or redistributing marked goods in a way that misleads consumers about quality or distribution limitations associated with the original producer is forbidden. ${ }^{210}$ Importing gray market marked goods is lawful under trademark law so long as the goods are "genuine," that is, they are not materially different from marked goods produced by or under the authority of the mark owner. ${ }^{211}$

American legal doctrine has been no more explicitly Hegelian than it has been explicitly Aristotelian, but the power and influence of thing-by-design should not be understated as a limit on the effective range of legal regulation. This is its principle virtue, particularly as thing-by-design blends, both knowingly and unwittingly, with thingby-nature. Individual autonomy occupies a central place in the history of Western thought, and recent developments in American property law point heavily toward personal control of both movable things and thing-interests. ${ }^{212}$ Thing-by-design emphasizes the role of the per-

${ }^{207}$ Enesco Corp. v. Price/Costco Inc., 146 F.3d 1083, 1085 (9th Cir. 1998).

${ }^{208}$ E.g., Champion Spark Plug Co. v. Sanders, 331 U.S. 125 (1947) (permitting sales of refurbished spark plugs under the Champion mark, so long as they were clearly sold as such; resale of repaired goods held acceptable unless repair renders the good no longer the "thing" it once was); Nitro Leisure Prods. L.L.C. v. Acushnet Co., 341 F.3d 1356 (Fed. Cir. 2003) (finding that refurbisher of golf balls marked with original mark adequately disclosed that balls were refurbished, even though the defendant re-applied the plaintiff's mark after refurbishing complete); Rolex Watch U.S.A., Inc. v. Michel Co., 179 F.3d 704, 710 (9th Cir. 1999) (allowing seller of reconditioned "Roixes" to retain "Rolex" trademark because the alteration made by the seller resulted in new product).

${ }^{209}$ E.g., Prestonettes, Inc. v. Coty, 264 U.S. 359 (1924).

${ }^{210}$ E.g., Davidoff \& Cie, S.A. v. PLD Int'l Corp., 263 F.3d 1297, 1302 (11th Cir. 2001) (finding infringement where reseller etched off batch codes on goods intended for domestic distribution); Wamer-Lambert Co. v. Northside Dev. Corp., 86 F.3d 3, 7 (2d Cir. 1996) (finding infringement in resales of cough drops whose expiration date had passed).

${ }^{211}$ E.g., SKF USA Inc. v. Int'l Trade Comm'n, 423 F.3d 1307 (Fed. Cir. 2005); WarnerLambert Co., 86 F.3d at 7-8; Lever Bros. v. United States, 981 F.2d 1330, 1338 (D.C. Cir. 1993); Original Appalachian Artworks, Inc. v. Granada Elecs., Inc., 816 F.2d 68, 73 (2d Cir. 1987); El Greco Leather Prods. Co. v. Shoe World, Inc., 806 F.2d 392, 395-96 (2d Cir. 1986).

212 See, e.g., Margaret Jane Radin, Property and Personhood, 34 STAN. L. REv. 957 (1982) (distinguishing objects for property purposes according to the extent to which they are 
sonal autonomy of inventors, creators, and suppliers and producers, and of autonomy generally, in promoting both a democratic political system and a market economy. Both substantively and rhetorically it connects an ontology of the world to some of the central commitments of the American political and economic system.

\section{THING-BY-CONTRACT}

The strengths of thing-by-design-its consistency with themes of autonomy and the natural order of things, its relative independence from problematic baseline questions, ${ }^{213}$ and its claim to superior competence in an area of discretionary decisions-simultaneously render it susceptible to two sorts of attacks. One resembles the challenge to thing-by-nature. If we regulate the thing by regulating its properties, then there is a sizable risk that we will get the specification wrong somehow, and the implicitly perpetual character of thing-by-nature means that the error may be difficult to correct. The same is true with respect to thing-by-design. We might regulate thing-by-design by shaping the design process, but regulation may miscalculate badly here too, either by yielding too much discretion to the designer, or too little. In the former case, error correction may again be problematic. For example, producers of certain manufactured things have begun to use thing-by-design to claim that a designed thing may not be repaired without the producer's permission. ${ }^{214}$ In the latter case, failure to respect the dynamic character of design may interfere with the evolution of things and practices by freezing them in outdated forms. Debates over the legality of distributing and using file sharing software are, in an important sense, debates about the design of things. ${ }^{215}$

bound up with our personal identities in the world). One strand of takings doctrine draws heavily on the autonomy interest of the property owner in making economically viable use of his or her property. See Keystone Bituminous Coal Ass'n v. DeBenedictis, 480 U.S. 470 (1987); Penn Cent. Transp. Co. v. City of New York, 438 U.S. 104 (1978).

213 Notwithstanding ever-present concems with the extent of meaningful autonomy in any individual case, and with whether firms should be invested with privileges of autonomy comparable to those enjoyed by human beings.

${ }^{214}$ See Storage Tech. Corp. v. Custom Hardware Eng'g \& Consulting, Inc., 421 F.3d 1307 (Fed. Cir. 2005). In England, a similar analysis supported a recent judgment in favor of the vacuum cleaner manufacturer Dyson against a competitor that sold copies of spare parts for the machines. See Dyson Ltd. v. Qualtex (UK) Ltd. [2004] EWHC 2981 (Ch). The exclusive rightto-repair follows earlier cases upholding an exclusive right-to-service. See, e.g., Triad Sys. Corp. v. Southeastem Express Co., 64 F.3d 1330 (9th Cir. 1995); MAI Sys. Corp. v. Peak Computer, Inc., 991 F.2d 511, 518 (9th Cir. 1993).

215 See supra notes 162-64 and accompanying text. On the idea of the evolution of material culture, see Belinda Barnet, Technical Machines and Evolution, CTHEORY, Mar, 3, 2004, at a139, http://www.ctheory.net/text_file.asp?pick=414 (last visited March 9, 2005); Niles Eldredge, Biological and Material Cultural Evolution: Are There Any True Parallels?, 13 PERSP. 
Second, and related, is the problem of spillover or distributional effects. The design of a thing may impact individuals and communities who are not the "intended" targets of the design. ${ }^{216}$ What is worse, the apparent naturalism of the designed thing may lead affected individuals or communities systematically to understate the scope of those effects. $^{217}$

A third model of things appears to avoid the unilateralism of the design approach and not to conceal the artificiality of its objects. It does not rely on a metaphysical, ontological sense of the real. Instead, it asks, why not trust the market to deal with the issues of thingness? "The market" is obviously a manufactured thing in itself; what "the market" means in this Part is the notion that things can be defined and classified via voluntary two-party transactions. Set aside, for the moment, the oft-repeated and never completely refuted objections to market discipline of this sort-that markets offer incomplete and misleading choices (via network effects, capture of industry standards, incomplete information, and other market failures that lead to suboptimal design). ${ }^{218}$ And set aside, also, the various cognitive and other limitations on contracting decisions that limit the power of contractbased utilitarianism. The fact remains that across a broad range of legal disciplines and economic markets, things are what we agree that they are, and we value the fact that such a system appears to allow the

\section{IN ETHOLOGY 113 (2000).}

${ }^{216}$ This is the problem attacked by Julie Cohen's proposed "right to hack" a DRM system, postulated as a way of marrying copyright's preemption doctrine to the DMCA. See Julie E. Cohen, Copyright and the Jurisprudence of Self-Help, 13 BERKELEY TECH. L.J. 1089, 1141-42 (1998); see also Chander, supra note 36.

217 Modern research in cognitive psychology offers an intriguing possible explanation for why arguments that appeal to natural thingness may be persuasive, and why they should sometimes be distrusted. We may have distinct portions of our cognitive faculties specially devoted to recognizing and analyzing "things." Appeals to the naturalness of artificial things are especially useful, in law and elsewhere, precisely because we may be programmed to be receptive to them. But mistaking the artificial for the natural may prevent us from realizing certain benefits, or from avoiding certain costs. See STEVEN PINKER, HOW THE MIND WORKS 27-31 (1997) (considering the possibility that the human mind contains subsystems that are dedicated to different sorts of reasoning, about physical objects, logic, and so forth). If that is so, the research raises questions concerning the wisdom of regulation that lets producers design rules in, and take advantage of, a cognitive bias that may naturalize those design rules. Less speculatively, empirical psychology demonstrates the importance of framing to individual decision-making. See Daniel Kahneman \& Amos Tversky, Prospect Theory: An Analysis of Decision Under Risk, 47 ECONOMETRICA 263 (1979). If the design of the thing can be conceived of a part of the story of the thing, see ROSE, supra note 1, then it is clear that who is telling the story, or who controls the story, matters a great deal. See also Amos Tversky \& Daniel Kahneman, Rational Choice and the Framing of Decisions, 59 J. Bus. 251, 256-57 (1986) (describing how framing, among other cognitive biases, changes how a story is narrated).

218 These limitations, and the corresponding effects on future users of things, are the core of Joel Reidenberg's objection to the premise that the market should evaluate technical standards. Reidenberg, supra note 48. 
descriptive and normative value of things to emerge as a result of the preferences not only of their designers, but also of their consumers.

The intellectual and conceptual underpinnings of thing-by-contract should be clear enough without a detailed exposition here. There are more than faint echoes of social contract theory, running from Hobbes and Locke through Rousseau to Rawls, which argues that authority derives from the consent of those subject to it, rather than on the fiction that authority is "natural." Shubha Ghosh synthesizes both the political and economic dimensions of social contract theory in order to critique its usefulness as a policy tool, ${ }^{219}$ but his description, which is centered on Hobbes and Locke, highlights the sense in which the property dimensions of social contract theory empower individuals to frame and distinguish objects from the state of nature. Delineated things enable individual autonomy in the political sphere (thus implementing fully the sense that precontracting interests are genuinely individualistic), and it enables individuals to accumulate wealth in the economic sphere (thus implementing fully the sense that the primary motivation of the individual is self-interested and appropriative). ${ }^{220}$

Thing-by-contract is not based solely on theories of social contract, not least because social contractarians do not mean that social and economic reality really is the product of consent-based institutions. The social contract is a rationalizing device that allows us to comprehend the legitimacy of the relationships that surround us. Theoretical foundations for the concrete contractual character of our objects can be traced to formal "freedom of contract" principles associated originally with Adam Smith and today with judges and commentators grouped as legal economists, and with the original American Legal Realists.

From both perspectives, what I described in Part II as the evolving blending of "real" and "legal" things is not merely a by-product of the social and technological changes described in that Part. Blending them, via thing-by-contract, is precisely the point of both theory and practice. Felix Cohen described property as purely relational, lacking

219 See Shubha Ghosh, Patents and the Regulatory State: Rethinking the Patent Bargain Metaphor After Eldred, 19 BERKELEY TECH. L.J. 1315, 1321-28 (2004). As he observes, the fundamental problem with social contract theories generally is that they are static and bilateral. Circumstances change, but the terms of the bargain do not. They fail to acknowledge the multiplicity of interests implicated by social policy. And their legitimacy ex ante exists only with references to the alternatives presented, in context. See BRUCE ACKERMAN, SOCIAL JUSTICE IN THE LIBERAL STATE $\$ 66$ (1980).

220 See generally David Gauthier, The Social Contract as Ideology, 6 PHIL. \& PUB. AFF. 130 (1977) (describing contractarianism as supposing that bargains derive from pre-social needs). 
any object whatsoever. ${ }^{221}$ Wesley Hohfeld dismissed the very notion of rights in rem, preferring instead to characterize rights with respect to a thing (such as a copyright or a patent) as "multital" rights. ${ }^{222}$ Critical property theorists embraced the disappearance of the object and the adoption of the relational "bundle of sticks" metaphor, in order to articulate and remedy power imbalances embedded in traditional thing-oriented property jurisprudence. ${ }^{223}$ More recent scholars have noted that the Legal Realists did not discard objects entirely. ${ }^{224}$ Rather, they reconstructed things in terms of the relations they represent. This more measured view of legal history is shared by scholars known for working primarily within economic frameworks ${ }^{225}$ and by those known for working primarily in critical or other noneconomic frameworks. ${ }^{226}$ Though much of the recent discourse has been framed in terms of property interests, some have emphasized consent as the core mechanism of legitimacy even today. ${ }^{227}$ The balance of this Part describes how thing-by-contract plays a significant role in constructing both property and other kinds of things.

There is, for example, the bargain theory of patent law, manifest both at the level of the patent system as a whole ${ }^{228}$ and, more importantly and concretely, at the level of each issued patent. The invention protected by the patent, the thing itself, is the result of a deal between the inventor and the public. ${ }^{229}$ The inventor's part of the bargain is the set of exclusive rights secured by the patent. The public's part of the bargain is partly the disclosure of the invention that is mandated before the patent issues and partly the free use of the invention enabled

221 Felix S. Cohen, Dialogue on Private Property, 9 RutGers L. ReV. 357, 360-63 (1954). Cohen was inspired by twentieth century physics, which he took as rejecting the notion that physical reality required a position in space. But Cohen got his physics (and thus his metaphysics) wrong. Einstein did not deny the truth of reality, only the duality of space and time.

222 Wesley N. Hohfeld, Fundamental Legal Conceptions as Applied in Judicial Reasoning, 26 YALE L.J. 710 (1917).

223 See Grey, supra note 140; Vandevelde, supra note 26.

224 See supra note 4.

225 See Adam Mossoff, What Is Property? Putting the Pieces Back Together, 45 ARIZ. L. REV. 371, 418 (2003) (describing the core of property as "rights to acquire, use, and dispose of things").

226 See Radin \& Sunder, supra note 18.

227 See, e.g., Randy E. Barnett, The Sound of Silence: Default Rules and Contractual Consent, 78 VA. L. REV. 821 (1992).

228 See Pfaff v. Wells Elecs., Inc., 525 U.S. 55, 63 (1998) (describing the patent system as a "carefully crafted bargain that encourages both the creation and the public disclosure of new and useful advances in technology"); Ghosh, supra note 219, at 1319-21 (reviewing history of the patent system as a "quid pro quo," and urging rejection of bargain metaphor in favor of regulatory view of patent law).

229 Justice Story invoked the quid pro quo metaphor for patenting in Pennock v. Dialogue, 27 U.S. (2 Pet.) 1, 23 (1829). In Eldred v. Ashcroft, 537 U.S. 186, 215-17 (2003), the Court distinguished application of the bargain metaphor in patent law from its possible application to copyright law. 
after the patent expires. Not only does the bargain metaphor help commentators discuss and refine patent policy, ${ }^{230}$ but in practice it helps courts refine application of a variety of patent doctrines, and it helps us to appreciate the process of obtaining a patent in the first place. Patented things exist in law as claims, in which the bargain is crystallized and which in a very real sense -in light of the give-andtake between inventors and patent examiners-are products of agreements between inventors and the public. As I noted above, ${ }^{231}$ patent law vacillates between the sense that the invention is the claim itself, ${ }^{232}$ and the sense that the claim represents the invention. Thingby-contract illuminates strands of that jurisprudence that focus on the latter.

The Supreme Court's opinion in Festo Corp. v. Shoketsu Kinzoku Kogyo Kabushiki $\mathrm{Co}^{233}$ adopts the core notion that the point of the patent system is to bargain over the character of the thing itself, in the form of the claims. The case articulated circumstances under which applicant statements during patent prosecution would lead to prosecution history estoppel and limit the availability of the Doctrine of Equivalents to prove liability for infringement. Since "the nature of language makes it impossible to capture the essence of a thing in a patent application,"234 a patentee must be allowed recourse to the Doctrine of Equivalents to ensure that the scope of its legal rights corresponds to the thing invented. Equivalents liability cannot extend, however, to claim scope that the patentee has, in effect, bargained away, via representations and positions taken during the prosecution process. ${ }^{235}$ To the extent that the legitimacy of the bargain is under-

${ }^{230}$ See, e.g., Mark A. Lemley \& Kimberly A. Moore, Ending Abuse of Patent Continuations, 84 B.U. L. REV. 63, 95-96 (2004) (describing the benefits conferred or withheld under existing patent policy by deploying the bargain metaphor).

231 See supra notes $110-12$ and accompanying text.

232 See 35 U.S.C. \$112(2) (2000) ("The specification shall conclude with one or more claims particularly pointing out and distinctly claiming the subject matter which the applicant regards as his invention."); Festo Corp. v. Shoketsu Kinzoku Kogyo Kabushiki Co., 234 F.3d 558,621 (Fed. Cir. 2000) ("Inherent in our claim-based patent system is . . the principle that the protected invention is what the claims say it is, and thus that infringement can be avoided by avoiding the language of the claims." (quoting Slimfold Mfg. Co. v. Kinkead Indus., 932 F.2d 1453, 1457 (Fed. Cir. 1991))), vacated, 535 U.S. 722 (2001).

233535 U.S. $722(2001)$.

234 Festo Corp., 535 U.S. at 731; see also Autogiro Co. of Am. v. United States, 384 F.2d 391 (Ct. Cl. 1967) ("An invention exists most importantly as a tangible structure or a series of drawings. ... [The] conversion of machine to words allows for unintended idea gaps which cannot be satisfactorily filled. Often the invention is novel and words do not exist to describe it. The dictionary does not always keep abreast of the inventor. It cannot. Things are not made for the sake of words, but words for things. To overcome this lag, patent law allows the inventor to be his own lexicographer.").

${ }^{235}$ See Festo Corp., 535 U.S. at 736-38. Thing-by-contract does not explain the entirety of patent law, but it is clearly reflected in this instance. Note that the Doctrine of Equivalents may 
mined by the competence and knowledge of the parties, patent law takes an important step to resolve those problems by constructing the imaginary bargainer: the Person Having Ordinary Skill in the Art, or PHOSITA, whose perspective is critical to resolving most questions regarding the character of the bargain in a particular case. ${ }^{236}$

Trade secret and copyright law likewise rely heavily on thingness defined bilaterally. Any problem in trade secret law depends in the first place on the existence of a manufactured thing, a trade secret. As practicing lawyers know, the most effective way to create that secret, and thereby to obtain trade secret protection for some bit of information, is to ensure that all parties to the information-employees, joint venturers, contractors, and so forth-agree expressly that the material to which they are given access is and should be treated as a trade secret. $^{237}$ The formalities of contract-based trade secret protectionstipulations that the contract covers trade secret subject matter and that protection for the secrets consists of the contractual creation of a confidential relationship ${ }^{238}$ - may be collapsed by practitioners and courts into this single, practical standard: did the parties to the contract agree that some process, technique, or other information constitutes a trade secret, a thing, to be protected by law? The agreement defines the thing. Breach of the agreement constitutes appropriation of the thing. ${ }^{239}$ The technique is particularly well known in transac-

be characterized as bridging the gap between thing-by-contract and thing-by-nature, to avoid uncritical reliance on the precise language of the claims themselves, and to apply the bargain construct of patent policy to the invention itself.

236 See Dan L. Burk \& Mark A. Lemley, Policy Levers in Patent Law, 89 VA. L. REV. $1575,1648-51$ (2003).

${ }^{237}$ In some states, contractual protection for material designated as a trade secret may exceed the scope of protection available at common law. See, e.g., Richardson v. Suzuki Motor Co., 868 F.2d 1226 (Fed. Cir. 1989) (applying California law). Adam Mossoff argues that trade secrecy is grounded in possession and use, rather than in obligation, that is, thing-by-design rather than thing-by-contract. See Mossoff, supra note 225, at 415-17.

238 The Uniform Trade Secrets Act defines "trade secret" so as to encompass the possibility of contractual creation of a confidential relationship, and defines misappropriation so as to include breach of a contractual obligation of confidentiality. A trade secret is "information, including a formula, pattern, compilation, program, device, method, technique, or process, that: (i) derives independent economic value, actual or potential, from not being generally known to the public or to other persons who can obtain economic value from its disclosure or use; and (ii) is the subject of efforts that are reasonable under the circumstances to maintain its secrecy." Uniform Trade Secrets Act \& 1(4) (1985). "Misappropriation" of a trade secret includes disclosure of use of the trade secret by one who was under an obligation to maintain its secrecy. Id. $\S 1(2)(\mathrm{ii})(\mathrm{B})(\mathrm{II})$.

239 Vincent Chiappetta proposes that all contract-based trade secret cases be interpreted in precisely this way, in light of the policies of trade secret law. See Vincent Chiappetta, Myth, Chameleon or Intellectual Property Olympian? A Normative Framework Supporting Trade Secret Law, 8 GEO. MASON L. REV. 69, 96-101, 149-50 (1999) (proposing a reconstruction of trade secret law that divides breach of duty cases, and particularly contract-based cases, from "bad acts" cases). 
tions involving computer software, ${ }^{240}$ but there is no principled or practical reason explaining why this is or should be so. Firms use nondisclosure agreements to create trade secrets based on contract rather than based on common law or statutory definitions, and in many cases, courts have endorsed these agreements. ${ }^{241}$

Relying on contractual trade secret status as a foundation for a misappropriation claim is controversial in the context of software distributed under shrink-wrap or click-wrap licenses, ${ }^{242}$ given the conflict between the allegedly "secret" status of the information and the fact that it is broadly distributed under agreements that impose confidentiality obligations that are all but unenforceable. No reported decision has passed on the claim that such wide distribution of software defeats a trade secret claim brought by the developer, ${ }^{243}$ but thing-bycontract in the context of computer programs and data has moved elsewhere nonetheless, away from its original focus on trade secrecy, and toward the model of licensing the software copyright described earlier. Whereas the last Part described the software license model as a key example of thing-by-design, this Part describes it, with a slightly different emphasis, as a key example of thing-by-contract.

Software licensing is a perplexing phenomenon in the law because it relies ambiguously but simultaneously on two legal predicates. There is the traditional concept of licensing as permission granted unilaterally, perhaps (but not necessarily) in exchange for royalties or a fee. In this sense, the software license represents thing-by-design. The producer controls the thing and the terms on which it may be used. There is, in addition, a more recent concept of agreement, in which the licensor promises to provide material for some specified use by the licensee, and the licensee promises not only to pay the licensor but also to refrain from certain specified acts. The promise not

${ }^{240}$ See, e.g., Micro Data Base Sys., Inc. v. Dharma Sys., Inc., 148 F.3d 649, 654 (7th Cir. 1998) (finding that Article 2 of the U.C.C. applies to a contract for the sale of custom software).

${ }_{241}$ See, e.g., Celeritas Techs. Ltd. v. Rockwell Int'l Corp., 150 F.3d 1354, 1359-60 (Fed. Cir. 1998) (holding that issuance of patent does not extinguish trade secret status of underlying information); IDX Sys. Corp. v. Epic Sys. Corp., 285 F.3d 581, 585 (7th Cir. 2002) (upholding right to contract to protect proprietary information that is not otherwise secret); Bernier v. Merrill Air Eng'rs, 770 A.2d 97, 103 (Me. 2001) (noting that a confidentiality agreement need not be limited to information meeting definition of trade secret).

${ }^{242}$ The controversy, which involves the effectiveness of a "trade secret" label attached to a product distributed to millions of consumers, is summarized in Mark A. Lemley \& David McGowan, Legal Implications of Network Economic Effects, 86 CAL. L. REV. 479, 528 \& n.211 (1998).

243 An unreported district court decision found that mass distribution did defeat a software developer's entitlement to an injunction for misappropriation of trade secrets. See Stac Elecs. v. Microsoft Corp., CV-93-413-ER (C.D. Cal. May 13, 1994 and June 8, 1994), reported in 48 PAT. TRADEMARK \& COPYRIGHT J. (BNA) 165 (1994), appeal voluntarily dismissed, 38 F.3d 1222 (Fed. Cir. 1994). 
to engage in reverse engineering of the software is the most important of these supplemental stipulations, both because of its obvious inconsistency with the default rules of the Copyright Act, ${ }^{244}$ and because of its central importance in defining the thing that is the subject of the parties' agreement. This is the sense in which the software license represents thing-by-contract. The software user, having agreed not to reverse engineer the program, has acquired use of a different thing. The agreement transforms the program from one thing into another. A computer program delivered under the default provisions of the Copyright Act (like a computer program acquired subject to an obligation to maintain trade secrets) is subject to reverse engineering. The program has the equivalent of a soft shell. It can be opened and examined. A program acquired under a license with an enforceable "no reverse engineering" clause is akin to a program with a hard shell. No examination is allowed.

Where thing-by-design looks at software licensing as a matter of regulating the work/medium distinction and first sale interests of users and consumers, thing-by-contract focuses on the agreement as the source of the object. This permits ignoring reverse engineering and first sale "rights" as substantive concerns of intellectual property policy and makes the contract itself the relevant thing. Shrink-wrapped and click-wrapped "goods" and services become distinct things. This is the approach of shrink-wrap and click-wrap agreement jurisprudence, with ProCD, Inc. v. Zeidenberg ${ }^{245}$ at its intellectual core. In exchange for things of a certain sort, consumers pay what courts believe to be lower, or at least fair, prices. ${ }^{246}$

The district court opinion in Davidson \& Associates $v$. Internet Gateway, Inc. ${ }^{247}$ captures this perspective. A developer of an online multiplayer computer sued a group of defendants who created an unauthorized version of the game environment, reverse engineering the original in violation of an End User License Agreement: "the defendants did not purchase the [plaintiff's] Blizzard software, rather they purchased a license for the software, ${ }^{248}$ not the software, or a copy of

244 Bowers v. Baystate Techs., Inc., 320 F.3d 1317, 1335-38 (Fed. Cir. 2003) (Dyk, J., concurring in part and dissenting in part); supra note 129 and accompanying text.

24586 F.3d 1447 (7th Cir. 1996).

246 The operative principle of the case law may be summed up in the phrase, "you get what you pay for." See Adobe Sys. Inc. v. One Stop Micro, Inc., 84 F. Supp. 2d 1086, 1091-92 (N.D. Cal. 2000); I.Lan Sys., Inc. v. Netscout Serv. Level Corp., 183 F. Supp. 2d 328, 338 (D. Mass. 2002); Monsanto Co. v. McFarling, 302 F.3d 1291, 1299 (Fed. Cir. 2002); ProCD, Inc., 86 F.3d at 1453; M.A. Mortenson Co. v. Timberline Software Corp., 998 P.2d 305, 314 (Wash. 2000).

247334 F. Supp. 2d 1164 (E.D. Mo. 2004), aff'd sub nom. Davidson \& Assocs. v. Jung, 422 F.3d 630 (8th Cir. 2005).

248 Id. at 1177. 
the software. Patent cases characterized in the last Part as enforcing servitudes on chattels fit the thing-by-contract model equally well, to the extent that the Federal Circuit and lower courts have emphasized that restrictive notices on patented products are enforceable by virtue of their mimicking a formal assent model. In the words of one court discussing seeds whose use was subject to a restrictive notice derived from two patents, "The seeds were no longer simply "seeds.,"249 Though the practice is characterized as "limited label licensing," courts emphasize not only the producer/patentee's power to condition distribution of the patented thing (thing-by-design) but also the fact that in form, at least, these licenses take the form of contracts (thingby-contract). The dual basis of such restrictions has been most clear in cases involving patented seeds, ${ }^{250}$ but contractual dimensions appear to have been critical in the Federal Circuit's rejection of a restrictive notice claim involving disposable cameras in Jazz Photo $v$. International Trade Commission, ${ }^{251}$ and in the court's acceptance of a restrictive notice that accompanied a medical device in Mallinckrodt $v$. Medipart. ${ }^{252}$ The point is that the courts are concerned with the character of the relevant thing, and they locate that character in a formal agreement that creates the thing.

A final example picks up on the themes noted in Part II of this Article, which described the increasing reconfigurability of our material environment, and particularly its electronic dimensions, as a justification for exploring the meaning of thingness in the first place. That concern was not evident in descriptions of thing-by-nature, largely because the naturalness of that model assumes a fundamentally changeless world. Thing-by-design assumes a certain degree of contingency, but the tendency to naturalize and therefore conceal its workings also tends to obscure its connections with the reconfigurability premise. Thing-by-contract, however, treats virtual, social, and material worlds all explicitly as bargains. Everything is subject to negotiation. It is little surprise, then, that the context in which thing-

249 Farmland Mut. Ins. Co. v. Scruggs, 886 So. 2 d 714 (Miss. 2004).

${ }^{250}$ Limited label licenses or other licenses restricting reuse of bioengineered agricultural products have been enforced in a number of cases. See J.E.M. AG Supply, Inc. v. Pioneer HiBred Int'l, Inc., 534 U.S. 124 (2001); Pioneer Hi-Bred Int'l, Inc., v. Ottawa Plant Food, Inc., 283 F. Supp. 2d 1018 (N.D. Iowa 2003); Monsanto Co. v. Ralph, 382 F.3d 1374 (Fed. Cir. 2004); McFarling, 302 F.3d 1291; Monsanto Co. v. Good, No. Civ.A.01-5678 FLW, 2004 WL 1664013 (D.N.J. July 23, 2004); Monsanto Co. v. Swann, 308 F. Supp. 2d 937 (E.D. Mo. 2003); Monsanto Co. v. Scruggs, 249 F. Supp. 2d 746, 754 (N.D. Miss. 2001); Monsanto Co. v. Trantham, 156 F. Supp. 2d 855 (W.D. Tenn. 2001).

231264 F.3d 1094, 1108 (Fed. Cir. 2001) ("It was undisputed that no express conditions of sale, license terms or restrictions attended the sale of these cameras. There was no express contractual undertaking by the purchaser.").

252976 F.2d 700, 709 (Fed. Cir. 1992). 
by-contract is most clearly evident is electronic data itself. Individual pieces of electronic data tend to be like ideas and facts in copyright law. They are ethereal and intangible, difficult to classify and more difficult to protect. ${ }^{253}$ Agreements can thingify data. ${ }^{254}$ The plaintiff in ProCD converted the contents of telephone books from across the United States into a single electronic database. Under copyright law, each telephone number would have been treated as an unprotectible fact, and the database itself also would likely have been regarded as an unprotectible collection of facts. ${ }^{255} \mathrm{Via}$ a contract that prohibited reposting any of the contents of the database on a computer network (such as the Internet), ProCD succeeded in making each phone number a legal thing, protected by contract law. ${ }^{256}$ Equivalent protection, based directly or indirectly on assent to or knowledge of a claim of right to control the use of data, has been extended to databases and data consisting of prices of overseas trips, ${ }^{257}$ registration information for Internet domains, ${ }^{258}$ prices of items up for electronic auction, ${ }^{259}$ and real-time scores of a professional golf tournament. ${ }^{260}$ In the eyes of the law, and given the presence of various mechanisms of assent, they are all recognizable things.

The Realist premises of thing-by-contract appear clearly in recent developments in copyright law, in models of "open source"

253 See J.H. Reichman \& Pamela Samuelson, Intellectual Property Rights in Data?, 50 VAND. L. REV. 51, 64-69 (1997).

254 For different views of the data protection problem, see Gibson, supra note 48, at 23040 (describing "re-reification" solution to database protection); Maureen A. O'Rourke, Shaping Competition on the Internet: Who Owns Product and Pricing Information?, 53 VAND. L. REV. 1965 (2000) (describing implications of price ownership for competition).

255 See Feist Publ'ns, Inc. v. Rural Tel. Serv. Co., 499 U.S. 340 (1991).

${ }^{256}$ See ProCD, Inc. v. Zeidenberg, 86 F.3d 1447, 1453-55 (7th Cir. 1996).

257 See EF Cultural Travel BV v. Zefer Corp., 318 F.3d 58, 63 (1st Cir. 2003) (upholding injunction under Computer Fraud and Abuse Act for "unauthorized" access to computer database and noting that database owner may rely on Web site notice of terms of use to withdraw consent to access).

${ }^{258}$ Register.Com, Inc. v. Verio, Inc., 356 F.3d 393, 402 (2d Cir. 2004).

259 See eBay, Inc. v. Bidder's Edge, Inc., 100 F. Supp. 2d 1058, 1070 (N.D. Cal. 2000). eBay's claim that the defendant unlawfully appropriated its auction data via electronic means relied on the common law tort of trespass to chattels, not on breach of contract, but the underlying structure of the argument is the same in both cases. Bidder's Edge acted in contravention of actual and constructive (i.e., electronic) notice of eBay's objection. The court noted that granting eBay's suit was prompted at least in part by the company's desire to improve its negotiating position with Bidder's Edge, id. at 1064 n.9, and, as David McGowan argues, the result may be justifiable on the ground that it encourages bargaining over valuable but intangible things. David McGowan, Website Access: The Case for Consent, 35 LoY. U. CHI. L.J. 341, 341-42 (2003).

260 Morris Commc'ns Corp. v. PGA Tour, Inc., 364 F.3d 1288, $1295-96$ (11th Cir. 2004). The case is thematically inconsistent with National Basketball Ass' $n$ v. Motorola, Inc., 105 F.3d 841 (2d Cir. 1997) (holding that real-time scores of professional basketball games likely could not be the subject of misappropriation claim), though the latter case did not involve a contract claim. 
software licensing, sometimes known as "Free and Open Source Software," or F/OSS. "Open source" licensing refers to a license regime under which the source code of a computer program is made available to users of a program's executable form and users are free to access, modify, and redistribute that source code, so long as any redistribution remains subject to the open access and modifiability provisions that accompanied receipt and use of the earlier version.

Whether the license terms are enforceable legally is unclear. What does seem certain is that the license form coordinates relationships among users and developers of a computer program, who may not be part of a traditional firm and may otherwise be separated significantly in time and space. ${ }^{261}$

To the critical commentator, an open source community and program are relation-based responses to an oppressive scheme of default intellectual property rights. To the Coasean commentator, they are alternatives to the firm as solutions to transaction costs obstacles in a complex market environment. In either case, or in both, an open source program is a dynamic and relational thing, or thing-bycontract. The open source example demonstrates vividly how thingby-contract redresses inequitable concentrations of power and authority implicit in a traditional and static view of things. Thingness suffers from the weaknesses inherent in systems that concentrate knowledge and power at the center, rather than distributing it. ${ }^{262}$ Thing-by-nature and thing-by-design each implies that the thing-maker knows best, when a properly distributed system may know better. The physical reality of technological artifacts, literally and metaphorically, both software and hardware, is inescapable. So is the fact that technology allows us to encode "relationships" relatively purely and precisely into those artifacts. Under a thing-by-contract model, F/OSS takes the conditions of the world and cures the inequities of thing-by-nature and thing-by-design by taking the material and legal reconfigurability of things to its logical extreme. An open source program is literally what its users agree that it is.

The respectable Legal Realist pedigree of thing-by-contract comes with an equally respectable Legal Realist critique. Thing-by-contract takes the state of the pre-assent world for granted. In many cases, if not all, the recognition and allocation of things worth bargaining over

261 See Yochai Benkler, Coase's Penguin, or Linux and The Nature of the Firm, 112 YALE L.J. 369 (2002) (analyzing distributed production processes).

262 See JAMES C. SCOTT, SEEING LIKE A STATE (1998) (noting, following Hayek and von Mises, the governance problem inherent in ex ante arguments for concentrations of knowledge, authority, and decision-making power in the state). 
is an inescapable problem. ${ }^{263}$ Assent implies choice, knowledge of choices, and capacity to bargain, or at least to choose. Some or all of these may be lacking, particularly to the extent that the model fails to fit our intuitions about the world. In many cases where the model is particularly powerful, as in shrink-wrap and click-wrap agreements and notice-and-acknowledgement frameworks that turn data into things, thing-by-contract implies that we are making choices when we are not aware of doing so. Those making choices may thingify too much, if they undervalue negative distributive and downstream consequences of their bargains, an especially difficult problem if thingbargains with authoritative implications are durable. They may thingify too little, if they undervalue positive consequences. ${ }^{264} \mathrm{Bar}-$ gaining to create things has the effect of commodifying objects and concepts that ought not to be commodified under any circumstances, as matters of public policy. ${ }^{265}$ We may end up, in short, with a surplus of bad thing-bargains and an insufficient number of good thingbargains. ${ }^{266}$ In the context of thing-by-contract, regulators can deal with these problems on a bargain-by-bargain basis, and make productive use of the thing-by-contract model, by addressing the salience and the significance of the practice of assent.

Perhaps the most troubling dimension of thing-by-contract is not its implicitly one-dimensional model of the process of bargaining itself, but its failure to articulate a connection between the single bargain or "private ordering" that constitutes the thing itself, and the market in things that supposedly results. As Mark Lemley recently argued in connection with economic justifications for intellectual property rights, the "private ordering" model is incomplete without the discipline of the market as a whole. ${ }^{267}$ Things exist not only in a bilateral, static sense, between two people, but also in an aggregate, dynamic sense, in the world at large. ${ }^{268}$ Thing-by-contract in isolation

${ }^{263}$ See Mark A. Lemley, Ex Ante Versus Ex Post Justifications for Intellectual Property, 71 U. CHI. L. REV. 129 (2004); Margaret Jane Radin \& R. Polk Wagner, The Myth of Private Ordering: Rediscovering Legal Realism in Cyberspace, 73 CHI.-KENT L. REV. 1295 (1998).

${ }^{264}$ See Brett M. Frischmann, An Economic Theory of Infrastructure and Sustainable Infrastructure Commons, 89 MiNN. L. REv. 917 (2005).

265 Radin \& Sunder, supra note 18, at 19-20. Davis Baird argues that commodification and thingness ought to be distinguished. Things are knowledge-bearing objects; commodities are not. The difference lies in the extent to which thingness supports sharing and the gift economy. Commoditization undermines that dimension of things. See BAIRD, supra note 18, at 211-37.

${ }^{266}$ And who is to say which is which? Thing-by-contract as a descriptive model is often coupled, implicitly or explicitly, with a normative framework that justifies bargains as welfareenhancing or even maximizing.

${ }^{267}$ Lemley, supra note 263 , at $148-49$.

${ }^{268}$ At the extreme, post-structuralist literary theory suggests that literary things (i.e., texts) have no static meaning even in a bilateral author/reader relationship. The difficulty of translating that perspective to law shows just how important the text itself remains. See Robert H. 
is risky if it produces a world in which a single object is represented as multiple sorts of legal things, depending on the kinds of bargains to which it is subject, without a method for reconciling them. In its best form then, thing-by-contract cannot exist in a vacuum. One must appreciate the broader context of the bargain.

\section{THING-BY-PRACTICE}

In this contextual form, however, thing-by-contract becomes a different model, which I call thing-by-practice. ${ }^{269}$ A patented technology may not be the subject of trade secret protection, but a patentee might use a contract to try to capture a technology that has passed into the public domain-for example, by requiring a patent licensee to pay royalties even after the patent expires. Doctrinally, preemption keeps thing-by-contract within its proper limits. The patent bargain takes precedence over a private bargain. Under Brulotte v. Thys Co. ${ }^{270}$ the patented thing cannot be resurrected under the guise of a contract, and the patented thing disappears along with the patent. Preemption, in this example, comes from somewhere; in this case, it comes from the public domain, which is the broader context of the bargain. Thing-by-practice, then, does more than sand the rough edges of thing-by-contract by contextualizing the practice of assent. Thing-by-practice takes the question of aggregating individual preferences and frames it explicitly as the question of social practices, rather than as an individual choice. It looks directly at things as how they are used, rather than as how they are given or created. Thingness is treated as based not merely on context (in an

Rotstein, Beyond Metaphor: Copyright Infringement and the Fiction of the Work, 68 CHI.-KENT L. REv. 725 (1993) (arguing that post-structuralist literary theory suggests revisions to copyright law's traditional focus on the "work of authorship," such as expanding application of the idea/expression distinction to address use of code and convention by alleged infringers).

${ }^{269}$ New Historicist critics allege a dynamic relationship among the authority of the text or thing itself, of the author or designer of the thing, of the individual reader, and of the larger social processes engaged in the production, use, and interpretation of the thing. The poststructuralist and postmodern argument that the aesthetic (read: the relationship) is everything, see Jean Baudrillard, Simulacra and Simulation (Sheila Faria Glaser trans., 1994), is supplemented by recognition of the ongoing and simultaneous role of the material (read: the thing). See, e.g., STEPHEN GReENBlatt, RenaisSANCE SElf-Fashioning: From MORE to SHAKESPEARE (1980). Literary criticism and cultural critique are integrated, with the critic's role being to investigate "both the social presence to the world of the literary text and the social presence of the world in the literary text." Id. at 5 .

270379 U.S. 29 (1964); Scheiber v. Dolby Labs., Inc., 293 F.3d 1014 (7th Cir. 2002) (following but criticizing Brulotte); see also Aronson v. Quick Point Pencil Co., 440 U.S. 257 (1979) (upholding a royalty agreement on an invention for which patent protection was sought, but not granted). 
important sense, property rights have always been contextual ${ }^{271}$ ) but explicitly on norms governing distribution and consumption regarding a particular referent in that context. Thingness is not defined by the producer, but by the audience, or by consumers, whether via "the market" or some other or additional mechanism. Meaning-making is a cultural practice. ${ }^{272}$ One might even make the argument that meaningmaking is a matter of unilateral decision-making by consumers, rather than by designers, ${ }^{273}$ but the question of thing-making by individual consumers is better regarded as another instantiation of thing-bydesign. ${ }^{274}$ This is thing-by-practice.

How is one to know whether and when a practice exists that defines a thing? It should be evident already that the modern edges of discrete models of thing-by-nature, thing-by-design, and thing-bycontract begin to blend not only toward one another, but toward this particular result. Things are defined by context, and the question is to define and describe that context more or less broadly. ${ }^{275}$ Viewed purely from the standpoint of the model's potential as a regulatory resource, thing-by-practice (whether viewed as an evolution from earlier models, or as a discrete model of its own) suggests a greater variety of particular tools, given the dynamic character of practices in the world. But there have to be limits of some sort. Otherwise, both practices and things devolve into formless, unstable blobs.

Defining those limits, that is, understanding what thing-by-practice actually means, is one of the central questions of twentieth century philosophy and social science. Even a brief review of those disciplines demonstrates just how difficult it is to confine thing-bypractice at any level, general or specific. From one perspective, the question most closely resembles the concerns of philosophical subjec-

${ }^{271}$ See Thomas W. Merrill, The Landscape of Constitutional Property, 86 VA. L. REV. $885,979-80$ (2000) (arguing that formal legal definitions of property cannot diverge too far from social practice without losing all semblance of legitimacy).

${ }^{272}$ See, e.g., Michael Madow, Private Ownership of Public Image: Popular Culture and Publicity Rights, 81 CAL. L. REv. 127 (1993) (arguing for limits on right of publicity based on communitarian sense of the "meaning-making" inherent in the fame that underlies the right).

${ }^{273}$ See F. Gregory Lastowka \& Dan Hunter, The Laws of the Virtual Worlds, 92 CAL. L.

REV. 1, 51-54 (2004) (considering the scope of the authority of avatars-representations of players-in online multiplayer game environments).

274 The idea that the individual consumer has the authority unilaterally to decide what the thing "is" has been rejected, in copyright cases at least. See N.Y. Times Co. v. Tasini, 533 U.S. 483 (2001) (finding implicitly that a print newspaper retains its character as a newspaper notwithstanding the consumer's ability to extract individual articles via an electronic database); UMG Recordings v. mp3.com, Inc., 92 F. Supp. 2d 349 (S.D.N.Y. 2000) (finding implicitly that consumers are not permitted to convert album recordings to digital singles via an Internet storage system).

275 See Bernstein, supra note 4, at 351-52 (arguing that images or representations of objects are necessary to law, in contrast to mere abstractions; the basics of human cognition dictate that images of objects are necessary constituents of our understanding). 
tivism, most often associated in the twentieth century with the later work of Wittgenstein. Wittgenstein argued that a thing should be understood in terms of having a concept of the thing, and that concepts, in turn, should be understood in terms of practical abilities: the ability to classify things or to recognize things or to make inferences, in a "language-game." 276 Wittgenstein distinguished the (Kantian and Cartesian) Realist theory that ideas or concepts are objectively "real," such that having an idea is fundamentally a matter of contemplating or viewing an "object," in other words, that ideas are mental particulars or objects in the mind, to be distinguished from particular instances or objects in the world. ${ }^{277}$

Words and language serve as authoritative symbols not of an underlying reality; instead, they derive their meaning and authority from their use in context (Wittgenstein thus offered a pragmatic account of semantics). Symbols refer to concepts, which are patterns of relations, rather than to things or to objects. A word "means" the role it is employed to perform, and things are defined by our ability to sort things, not by their correspondence to a concept of a certain kind of thing. Wittgenstein used the phrase "family resemblances" to refer to these patterns. ${ }^{278}$ There is no such thing as pure symbol and no such thing as pure thing. There is only meaning via symbol plus use. In a related Wittgensteinian vein are pragmatist philosophers, ${ }^{279}$ institutional so-

276 WITTGENSTEIN, supra note $82, \S \S 6-17$.

${ }^{277}$ See id. $\S \S 1-3,15$.

The philosophic debate over the merits of concepts is intense. Defenses of objectivism include JERRY A. FODOR, CONCEPTS: WHERE COGNITIVE SCIENCE WENT WRONG (1998); Jerry Fodor, Having Concepts: A Brief Refutation of the Twentieth Century, 19 MIND \& LANGUAGE 29 (2004); BARRY STROUD, THE QUEST FOR REALITY: SUBJECTIVISM AND THE METAPHYSICS OF COLOUR (2000). Perhaps the most sophisticated contemporary advocate of subjectivist theory is Daniel Dennett, Real Patterns, 88 J. PHIL. 27 (1991), reprinted in DANIEL DENNETT, BRAINCHILDREN: ESSAYS ON DESIGNING MINDS (1998) (finding a middle ground in "real patterns" between the binary positions of ontology-reality is real (realism or naturalism, i.e., some things are real or naturally independent of and prior to our conception of them), or is illusory (instrumentalism)-in considering mental states). In this sense, Dennett argues that beliefs are "real." Id.

278 WITTGENSTEIN, supra note $82, \S \S 66-67$. Legal scholars have located Wittgenstein's influence in a wide range of legal issues, so that legal terms (such as "corporation," "negotiable instrument," or "privacy") are the products of institutional conventions that constitute legal discourse. Cf. H.L.A. Hart, Definition and Theory in Jurisprudence, 70 L.Q. REV. 37 (1954) (noting that concepts, such as "corporation," are really bundles of relationships that represent complex functions but do not describe or define anything).

279 See, e.g., BRANDOM, supra note 15, at 166-85 (following and extending Quine, by making reference to the central semantic concept, rather than meaning, and defining reference in terms of its pragmatic social and communicative role). On the relevance of this view to law, see Dennis M. Patterson, Law's Pragmatism: Law as Practice and Narrative, 76 VA. L. ReV. 937 (1990) (outlining a pragmatist theory of legal discourse, based on narrative; describing law as an activity, rather than a thing). But see Michael Steven Green, Dworkin's Fallacy, or What the Philosophy of Language Can't Teach Us About the Law, 89 VA. L. REV. 1897 (2003) (arguing that the philosophy of language has no jurisprudential consequences; i.e., that talking about or 
cial scientists, ${ }^{280}$ and some contemporary sociologists, anthropologists, and linguists, ${ }^{281}$ all of whom, in one way or another, argue that

recognizing something as law does not make it law).

In Part III supra, I distinguished practice that describes an objective thing (thing-bynature) from practice that constitutes a thing (thing-by-practice). It may be better to put the two perspectives on a philosophical continuum. See HAUGELAND, supra note 153, at 325-54 (distinguishing between science and games as metaphorical resources for thinking about different things, depending on the character of their authority); PUTNAM, supra note 153 (arguing that though meaning is usage, words have referents and offering his famous aphorism, "meaning just ain't in the head!"); QUINE, Ontological Relativity, supra note 9; Ronald J. Allen \& Brian Leiter, Naturalized Epistemology and the Law of Evidence, 87 VA. L. REV. 1491, 1493-99 (2001) (summarizing "naturalized" epistemology as based on empiricism about perceptions of human experience). Something "counts" as knowledge, in other words, if it is based on reliable cognitive processing, situated in social practices and processes that produce beliefs. Id. (citing and following Quine, Epistemology Naturalized, in QUINE, ONTOLOGICAL RELATIVITY AND OTHER EsSAYS, supra note 9, and ALVIN I. GOLDMAN, EPISTEMOLOGY AND COGNITION (1986)).

In a related spirit is Jeremy Bentham's distinction between "real" entities (objects existing in the material world) and "fictitious" entities (abstractions, which require language for their existence), see Jeremy Bentham, A Fragment on Ontology and Essay on Language, in 8 THE WORKS OF JEREMY BENTHAM (John Bowring ed., 1838-1843), a precursor to Hart, and later to Foucault. See H.L.A. Hart, The Ascription of Responsibility and Rights, 49 PROC. OF THE ARISTOTELIAN SOCIETY 171 (1948-1949), reprinted in LOGIC AND LANGUAGE 151 (Anthony Flew ed., 1965) (arguing that there are concepts with antecedents in the "world of facts," and concepts without, so that the questions, "what is a concept?" and "what is its authority?" ought to be separated); MiChel FouCAULT, The ARChaEOLOGY OF KNOWLEDGE 21-49 (A.M. Sheridan Smith trans., 1972) (1969) (distinguishing between discursive objects, which are interpretable, and material objects, which are not). Bentham's epistemology, however, was more pragmatic than ideal. Bentham "sought a method by the use of which the human mind could learn from, and build on, observation and experience. The task of such a logic, in his view, is to define strategies for the best use of the rational faculties, where 'best use' is defined in terms, ultimately, of successfully advancing human purposes and satisfying human needs and interests." Gerald Postema, BeNTHAM AND THE COMMON LAW TRADITION 60 (1986).

280 See Roger Friedland \& Robert Alford, Bringing Society Back In: Symbols, Practices, and Institutional Contradictions, in THE NEW INSTITUTIONALISM IN ORGANIZATIONAL ANALYSIS, supra note 172, at 232; Ronald L. Jepperson, Institutions, Institutional Effects, and Institutionalism, in THE NEW INSTITUTIONALISM IN ORGANIZATIONAL ANALYSIS, supra note 172 , at 143.

281 See, e.g., WIEBE E. BuKer, Of BiCyCles, BaKeltTES, AND BULbS: TOWARD A THEORY OF SOCIOTECHNICAL CHANGE (1995); Brown, supra note 1; GEORGE LAKOFF \& MARK JOHNSON, PHILOSOPHY IN THE FLESH: THE EMBODIED MIND AND ITS CHALLENGE TO WESTERN THOUGHT (1998); LATOUR, PANDORA's HOPE, supra note 39, at 304.

Social or conventional frameworks for things may support the naturalization phenomena (thing-by-practice or thing-by-design becomes thing-by-nature) described earlier. See supra notes $156-57$ and accompanying text. This process is inevitably practice-based, though precisely how it works - or how it might be interrupted-is not well understood. See Kathleen M. Carley, On the Evolution of Social and Organizational Networks, in 16 RES. IN THE SOC. OF ORG. 3-30 (David Knoke \& Steven B. Andrew eds., 1999) (describing model of socio-cognition in which knowledge networks (who knows what information, and what information is related to what), cognitive social structures (who knows whom), and individual cognitive networks (what each individual knows) coevolve); EDWIN HUTCHINS, COGNITION IN THE WILD (1995) (describing model of "distributed cognition"); Edwin Hutchins, Material Anchors for Conceptual Blends, 37 J. PRAGMATICS 1555 (2005) (describing "distributed cognition" as human thought grounded in material practice, rather than mental processes or structures, so that things are "cognitive artifacts"); Rajiv C. Shah \& Jay P. Kesan, The Recursive Regulatory Model (2004) (unpublished manuscript, on file with author) (postulating a theory of recursive engagement among individu- 
we use our shared experiences of the world, including our language, to construct the existence, meaning, and authority of things. ${ }^{282}$ From different traditions, Davis Baird (philosophy) ${ }^{283}$ and Etienne Wenger (cognitive psychology) ${ }^{284}$ generalize: "Things" are efficient bearers of knowledge and learning that are created by and bind social groups. Where twentieth century Realists draw a sharp distinction between what the philosopher Rudolf Carnap termed "synthetic truths" (mere "rules of language") and "analytic truths" ("matters of fact," known by experience), subjectivists and pragmatists reject that distinction. ${ }^{285}$ Truth follows from practice. ${ }^{286}$

Thing-by-practice is clearly pragmatic in this last sense, but there are those who are both convinced of the need to incorporate practice into a model of things, yet reject subjectivism. (Interestingly, recent research in cognitive neuroscience makes a related point: things may exist in our brains, not just in our minds. ${ }^{287}$ Their speculations offer an approach that, if successful, would marry the real and pragmatic theories of concepts to a pragmatic theory of material objects. A grand unified theory of things, in other words.) This is Martin Heidegger's approach, to center a philosophy not on the person (who

als, institutions, and objects, combining Latour's actor/network theory and the structuration theories of Giddens and Orlinkowski).

${ }^{282}$ Perhaps the most prominent contemporary legal philosopher working in this tradition is Frederick Schauer. See Frederick Schauer, Statutory Construction and the Coordinating Function of Plain Meaning, 1990 SUP. CT. REV. 231; Schauer, supra note 153.

${ }_{283}$ See BAIRD, supra note 18, at 118-65 (advocating a "materialist epistemology," or understanding things as forms of knowledge, even (or especially) when those things are not transparent).

284 See Etienne Wenger, Communities of Practice: Learning, Meaning, and IDENTITY 58-102 (1998) (describing how the authority of things derives from their social context, the complex social practices and conventions that mediate within and among communities).

285 See HIl.ary Putnam, The Collapse of the Fact/Value Dichotomy and Other ESSAYS (2002) (describing how modern philosophy and some modern economics recognize that description and evaluation infect each other, so that practice influences categories); QUINE, Ontological Relativity, supra note 9 (putting these phenomena on a single continuum).

286 See, e.g., Appadurai, supra note 18, at 5 (describing "the human transactions and calculations that enliven things," or "things-in-motion," that illuminate their human and social context); Aafke Komter, Heirlooms, Nikes and Bribes: Toward a Sociology of Things, 35 Soc. 59 (2001) (borrowing a taxonomy from Fiske to distinguish four ways in which people may relate to one another and to things, and noting that where parties to a transaction do not share the same frame, a thing may have conflicting social lives).

287 The economy of concepts emphasized by the discipline of concept learning, see Palmieri \& Noelle, supra note 1 , exists not merely as a mental or social convenience. It may exist at a psychological level. Concepts may constitute shared cognitive phenomena that permit generalization, inference, and different levels of abstraction. Concepts establish references, describe referents, and establish domains of reference. Meaning and communication proceed from that point. See Lawrence W. Barsalou \& Katja Wiemer-Hastings, Situating Abstract Concepts, in GROUNDING COGNITION: THE ROLE OF PERCEPTION AND ACTION IN MEMORY, LANGUAGE, AND Thought (Diane Pecheer \& Rolf A. Zwaan eds., 2005). 
interprets the world of things), ${ }^{288}$ but on things themselves. ${ }^{289} \mathrm{Hei}$ degger rejected theory altogether; when he asked, explicitly and bluntly, what is a thing? ${ }^{290}$ he answered that question directly in the form of experience, rather than by referring to artifacts or concepts. Heidegger distinguished between "present-at-hand" "objects" (Vorhandenhut), alienated from the self and available for detached examination, and "ready-to-hand" "things" (Zuhandenhut), as we use and experience them through time and space, ${ }^{291}$ or what modern sociologists might refer to as "situated" or "embedded" objects. Heideggerian "things" have no meaning in our lives apart from our practical experience of them, other than as objects of study. Thingness per se

288 The shared communicative dimension of thing-by-practice means that it retains the derivative weakness that language is itself colored by experience. See Edward L. Rubin, The Practice and Discourse of Legal Scholarship, 86 MICH. L. REV. 1835, 1840-41 (1988); cf. Oliver Wendell Holmes, Law in Science and Science in Law, 12 HARV. L. REV. 443, 460 (1899) ("We must think things not words, or at least we must constantly translate our words into the facts for which they stand, if we are to keep to the real and true."). Because of my own effort to categorize techniques of thing-making, I dodge the important question of the inevitability of our reliance on linguistic structures to access our experience, known generally as the "linguistic tum" in twentieth century theory. See John E. Toews, Intellectual History After the Linguistic Turn: The Autonomy of Meaning and the Irreducibility of Experience, 92 AM. HIST. REV. 879, 881 (1987) (book review).

${ }^{289}$ Heidegger regarded language as metaphysical, but in other respects his argument anticipated the work of contemporary cognitive linguists, who suggest that language is embodied experience. See GeOrge LakofF, WomEN, Fire \& Dangerous Things: What Categories REVEAL ABOUT THE MIND 5 (1987); Mark Johnson, Law Incarnate, 67 BROOK. L. REV. 949 , 957-59 (2002) (emphasizing the "embodied, situated" nature of concepts and rules, rather than the givenness of background assumptions regarding context).

290 See Martin Heidegger, What Is a Thing? (W.B. Barton, Jr. \& Vera Deutsch trans., 1967) (1935) [hereinafter HEIDEGGER, WHAT IS A THING?]. A thing is the existing (vorhanden) bearer of many existing yet changeable properties, i.e., systems of "something else." Heidegger earlier staked out "the thing" in practical terms to distinguish his theory from Kant's thing-assuch, or noumenon, referring to the thing (das Ding) in experiential terms, denoting a gathering of people, or an event. See Martin HeIDEgGER, The Thing, in POETRY, LANGuage, Thought 161 (Albert Hofstadter trans., 1971).

Heidegger's method followed the phenomenological philosophy of Edmund Husserl, which also inspired the hermeneutics of Gadamer and his followers. See EDMUND HUSSERL, IdEAs: General INTROduction to PURE PhenOMENOlogy 96, 105-20, 220-26 (W.R. Boyce Gibson trans., Collier Books 1969) (1931) (arguing that the world as an experienced thing precedes any questions about its metaphysical reality; to interpret an object is to make sense of the world and create meaning for ourselves). The creation of meaning via this "intersubjective" process-individual construction of the world, and sharing of that construction with others-is methodologically individualistic. Only individuals are intentional actors, and institutional behavior is accounted for only in terms of individual action. The hermeneutic tradition tries to capture the situated social dimension of interpretation. See HANS-GEORG GADAMER, The Nature of Things and the Language of Things, in PHILOSOPHICAL HERMENEUTICS, at 69-71 (David E. Linge ed. \& trans., 1976). For an application of the hermeneutic tradition to law, see George H. Taylor, Critical Hermeneutics: The Intertwining of Explanation and Understanding as Exemplified in Legal Analysis, 76 CHI.-KENT L. REV. 1101 (2000).

291 See MARTIN HeIDEgGER, BEING AND TIME 98-101 (John Macquarrie \& Edward Robinson trans., 1962) (1927). 
fails to represent the true character of the world as a dynamic negotiation between and among all of us living in it:

It now becomes clear that we understand the term "thing" in both a narrower and a broader sense. The narrower or limited meaning of "thing" is that which can be touched, reached, or seen, i.e., what is present-at-hand (das Vorhandene). In the wider meaning of the term, the "thing" is every affair or transaction, something that is in this or that condition, the things that happen in the world-occurrences, events. $^{292}$

"Things" in this sense do not occupy a distinct place in the Heideggerian universe. They become part of the ongoing interpretive state of Being that Heidegger called Dasein. ${ }^{293}$ Things are revealed via the Greek mode of techne, and the revealing itself draws out things. Being in the world is ontologically prior as a mode of revealing. Essence is not the unchanging stuff of Aristotle. It changes as we encounter things. ${ }^{294}$

Heideggerian "seeing that produces things" is complex enough in philosophical terms, even on the premise that it rejects theoretical construction in favor of the practical. Yet it is precisely in rejecting theory that the critique abandons the pretense that a common coherent framework could be worked out to identify a "thing" in any given legal context. ${ }^{295}$ Perhaps patent law, with its explicit concern for technical "things" and its Person Having Ordinary Skill in the Art (PHOSITA) construct for evaluating patent validity, comes closest to developing a mechanism for processing the kinds of experiential questions that Heidegger anticipated. ${ }^{296}$ In any other application, a theory of thing-by-practice requires a somewhat messy blending of Heidegger and Wittgenstein, with a dose of David Hume's conviction

292 HeIDEGGER, WHAT Is A THING?, supra note 290, at 5; see MARTIN HEIDEGGER, The Question Concerning Technology (1954), in BASIC WRITINGS 287 (David Farrell Krell ed., 1977) (relating things to the Greek techne, appreciating technological artifacts as we experience them, without reducing them to mere instruments).

293 See generally HEIDEGGER, supra note 291 (describing the structure of "everydayness," or "Being-in-the-world," an interconnected system of equipment, social roles, and purposes).

294 See MARTIN HeIDEgGer, BASIC Questions OF PHILOSOPHY 76-77 (Richard Rojcewicz \& Andre Schuwer trans., Indiana Univ. Press 1994) (1938).

295 Compare Linda Ross Meyer, Is Practical Reason Mindless?, 86 GEO. L.J. 647 (1998) (celebrating the openness to practical reason that Heidegger invites), with Brian Leiter, Heidegger and the Theory of Adjudication, 106 YALE L.J. 253 (1996) (attempting a theory of practical reasoning for adjudication, based on the Heideggerian critique).

296 See John R. Thomas, Of Text, Technique, and the Tangible: Drafting Patent Claims Around Patent Rules, 17 J. MARSHALL J. COMPUTER \& INFO. L. 219 (1998); see also Nard, supra note 82. 
that convention, rather than reason, was the source of knowledge, ${ }^{297}$ and empirical approaches from a variety of domains. ${ }^{298}$ In all, thingby-practice reflects a pragmatism that seems best to approximate the messiness of the world as we find it, but that some may reject as too complex and insufficiently precise.

Despite these practical difficulties, thing-by-practice is often effective in rebutting Realist criticism that the reification of legal concepts wrongly confuses the social and the natural. ${ }^{299}$ Part II of this Article built its premise largely out of an unarticulated thing-bypractice foundation, illustrating how the adaptability and flexibility of thing-by-practice means that it is both inevitable and at times beneficial, particularly when spillover or distributional issues can be addressed by broadening the community that defines "things." In property law, for example, Hanoch Dagan argues that the Realist conception of property as forms or relations can be recharacterized profitably along institutional, or practical, lines. ${ }^{300}$ In social terms, Dagan's thesis uses thing-by-practice to consolidate the expectations and forms of ideal relationship within a social group. ${ }^{301}$ Michael Carrier, Jacqueline Lipton, and Adam Mossoff have each reframed

297 See David Hume, A Treatise of Human Nature 484-513 (L.A. Selby-Bigge ed., 1978) (1739) (expressing skepticism regarding the power of positive law and noting the degree to which it should track social conventions); Henry E. Smith, The Language of Property: Form, Context, and Audience, 55 STAN. L. REv. 1105, 1128-30 (2003) (discussing Hume and the role of convention, rather than agreement, as answering questions regarding how objects become property).

298 See, e.g., Michael J. Madison, A Pattern-Oriented Approach to Fair Use, 45 WM. \& MARY L. REv. 1525 (2004) (advocating a practice-based or pattern-oriented approach to questions of fair use in copyright law).

${ }^{299}$ See Catherine L. Fisk, Removing the "Fuel of Interest" from the "Fire of Genius": Law and the Employee-Inventor, 1830-1930, 5 U. CHI. L. REV. 1127, 1135-36 (1998) (characterizing patents as reified legal things, fixing a particular social order); Douglas Litowitcz, Reification in Law and Law Theory, 9 S. CAL. INTERDISC. L.J. 401 (2000) (characterizing reification as the confusion of the natural and the social, and discussing reification theory of Georg Lukács and tracing it to the commodity fetishism described by Marx); Gary Peller, The Metaphysics of American Law, 73 CAL. L. REV. 1151 (1985) (taking a critical view of reification as fixing dynamic social relations in artificially "natural" arrangements); Steven L. Winter, Transcendental Nonsense, Metaphoric Reasoning, and the Cognitive Stakes for Law, 137 U. PA. L. REV. 1105,1108 (1989) (rejecting "objectivist" theories of cognitive processing, which treats the world as filled with "objects" that exist independent of human interaction).

300 See Hanoch Dagan, The Craft of Property, 91 CAL. L. REV. 1517 (2003).

${ }^{301}$ The conceptual link here is to Davis Baird's materialist epistemology of things, which holds that tangible things embody social knowledge in much the same sense that Dagan applies to institutions. See BAIRD, supra note 18. This mirrors the external perspective of Thomas Merrill and Henry Smith, see supra note 139 and accompanying text, and of Clarisa Long, see supra note 138 and accompanying text, that thingness offers information cost advantages, but combines it with an internal perspective that emphasizes the coherence of the thing itself. Dagan disagrees with the Merrill and Smith thesis that modern property rules are bounded by a numerus clausus principle, on the ground that the numerus clausus principle does not account for the internal governance function of institutions. See Dagan, supra note 300 , at 1567-68. But I suspect that the institutional model is elastic enough to account for his concern. 
intellectual property doctrines along property lines to emphasize the advantages of a thing-oriented approach from the standpoint of access to information. ${ }^{302}$ In economic terms, classical property rules on chattels $^{303}$ imply that the law expects the beneficiaries of thingness to internalize the costs of thing-formation. When there are barriers to fully internalizing those costs (and generating those benefits) via private transactions (for example, coordination costs or other cultural or social limitations prevent members of a group from expressing their preferences in a transactional setting), it makes sense to follow an approach to thingness that defines the thing (and absorbs its costs) in terms of shared practices.

Thing-by-practice encompasses intangible and conceptual things in the law as well as (and perhaps even more than) physical things. Property rights are at times the products not of what an "owner" claims as property, but as what some relevant community treats as property. This was ultimately the point of classic property cases such as Pierson v. Post ${ }^{304}$ and Ghen v. Rich, ${ }^{305}$ and it comes to us in cases such as G.S. Rasmussen \& Associates, Inc. v. Kalitta Flying Service, Inc., ${ }^{306}$ recognizing a property interest in an FAA airworthiness certificate for a particular aircraft design. Carol Rose notes that the question of property in things in these cases depends on the possibility of possession, not because of the inherent characteristics of the thing itself, but because of the communicative function of possession in the context of the symbolic practices of the group. ${ }^{307}$

302 See Michael A. Carrier, Cabining Intellectual Property Through a Property Paradigm, 54 DuKe L.J. 1 (2004); Jacqueline Lipton, Information Property: Rights and Responsibilities, 56 FLA. L. REV. 135 (2004); Adam Mosoff, What Is Property? Putting the Pieces Back Together, 45 ARIZ. L. REV. 371, 372-74 (2003) (describing intangible, intellectual property as not conceptually distinct from tangible property); $c f$. James Boyle, The Second Enclosure Movement and the Construction of the Public Domain, 66 LAW \& CONTEMP. PROBS. 33, 67-68 (2003) (analogizing the several forms of the public domain in intellectual property law to the several conceptions of "property"); Hope M. Babcock, Should Lucas v. South Carolina Coastal Council Protect Where the Wild Things Are? Of Beavers, Bob-o-Links, and Other Things That Go Bump in the Night, 85 IOWA L. REV. 849, 900-01 (2000) (describing "public trust" idea in environmental law as a reification of property's communal norms).

303 See supra notes 104-09 and accompanying text.

${ }^{304} 3$ Cai. 175 (N.Y. Sup. Ct. 1805) (holding that a property right in a fox does not arise via the chase).

3058 F. 159 (D. Mass. 1881) (holding that a property right in a whale may arise via harpooning it).

306958 F.2d 896, 902-03 (9th Cir. 1992) ("[T]hree criteria must be met before the law will recognize a property right: First, there must be an interest capable of precise definition; second, it must be capable of exclusive possession or control; and third, the putative owner must have established a legitimate claim to exclusivity." (footnote omitted)).

${ }^{307}$ Carol M. Rose, Possession as the Origin of Property, 52 U. CHI. L. REv. 73, 79-85 (1985). A "commonly understood and shared set of symbols ... gives significance and form to what might seem the quintessentially individualistic act: the claim that one has, by 'possession,' separated for oneself property from the great commons of unowned things." Id. at 88. 
Thingness is recognized as such not merely because of the value associated with the resulting property right, ${ }^{308}$ but because the community explicitly or implicitly acknowledges thingness in its context. Robert Ellickson's study of the social norms of California cattle ranchers is a justly famous example of social practices creating a legal institution with little "reality" behind it except the behavior of its participants. ${ }^{309}$ A para-legal regime based on social norms may be a conceptual thing-by-practice without a concrete referent. But comparable arguments have been made regarding tangible things, including books ${ }^{310}$ and automobiles. ${ }^{311}$

The relevant response of the community may be purely cultural, or commercial, or both. Copyright law specifically rejects thingness (and copyrightability) in certain cases under the doctrine of scenes à faire, on the ground that certain characters and settings are effectively generic to the type of expressive work involved. ${ }^{312}$ The rule exists to protect readers and other consumers in their ability to enjoy cultural traditions of certain sorts. A related doctrine in trademark law, that distinctive marks may lose legal protection if they become generic via use, ${ }^{313}$ exists to protect consumer and competitor access to that term in order to communicate about products of that class. The "staple item of commerce" doctrine in patent and copyright law limits application of doctrines of secondary liability for infringement when liability is premised solely on the defendant's sales of an item that may be used to infringe the plaintiff"s right. ${ }^{314}$ Copyright law borrowed the "staple item" concept from patent law but added the gloss that the item must be "capable" of "substantial noninfringing uses" or "commercially significant noninfringing uses,"315 a twist that highlights the role of

308 See Cohen, supra note 66.

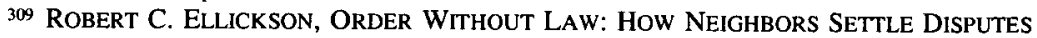
(1991).

310 See Random House, Inc. v. Rosetta Books L.L.C., 150 F. Supp. 2d 613, 621-22 (S.D.N.Y. 2001) (relying on industry practice to determine the meaning of the phrase "in book form" in publishing agreement), aff'd, 283 F.3d 490 (2d Cir. 2002).

${ }^{31}$ See Automatic Radio Mfg. Co. v. Ford Motor Co., 272 F. Supp. 744, 748 (D. Mass. 1967) (discussing Ford's argument that the design features of its dashboard, which disadvantaged after-market suppliers of automobile radios, were "important and essential components of an automobile in today's style-minded market"), aff'd, 390 F.2d 113 (1st Cir. 1968). The district court did not rely on Ford's argument in refusing to enjoin Ford's behavior.

${ }^{312}$ E.g., Murray Hill Publ'ns, Inc. v. Twentieth Century Fox Film Corp., 361 F.3d 312 (6th Cir. 2004).

${ }^{313}$ E.g., Yellow Cab Co. of Sacramento v. Yellow Cab of Elk Grove, Inc., 419 F.3d 925 (9th Cir. 2005); Ty Inc. v. Perryman, 306 F.3d 509 (7th Cir. 2002).

314 See 35 U.S.C. $\$ 271$ (c) (2000) (exempting sale of "staple article or commodity or commerce suitable for substantial noninfringing use" from patent liability); Sony Corp. of Am. v. Universal City Studios, Inc., 464 U.S. 417, 434-42 (1984) (borrowing patent rule for application to copyright law).

315 Sony, 464 U.S. at 442. 
commercial and cultural practice in defining the existence of the "staple item" in question. ${ }^{316}$

Thing-by-practice appears to have the greatest application in what are primarily commercial contexts. The question of distinctiveness in trademark law, for example, has traditionally been largely a function of how the mark is perceived in the relevant market. ${ }^{317}$ Barton Beebe concludes, "The trademark, then, is not an irreducible, indivisible thing, but rather a set of relations, specifically of semiotic relations of reference. It is more wave than particle." ${ }^{18}$ Cases questioning the legal thingness of FAA certifications do not arise frequently, but cases questioning the legal status of Internet domain names have become more common. For some purposes, and when there is some relevant commercial market, domain names are legal things. Kremen v. Cohen ${ }^{319}$ following G.S. Rasmussen, holds that domain names may be the subject of claims for conversion. They may be the object of in rem legal proceedings. ${ }^{320}$ They may be the objects of security transactions. ${ }^{31}$ When no relevant commercial practice is involved, domain names may not be things. They may not be garnished to satisfy a debt. $^{322}$

Similarly, whether a given transaction amounts to a security interest in personal property under the Uniform Commercial Code depends not on the characterization of the transaction by the parties, or even on the parties' intent, but on the economic characteristics of the transaction in the context of the market. ${ }^{323}$ Transactions in computer programs that involve distribution of a complete copy of a noncustomized program in exchange for payment of a one-time fee have been held to be subject to the rules of Article 2 of the U.C.C. ${ }^{324}$ The

316 See Madison, supra note 298, at 1662-77 (framing file sharing cases in terms of consumer practice).

317 See Steven Wilf, Who Authors Trademarks?, 17 CARDOZO ARTS \& ENT. L.J. 1, 10 (1999) (describing the public as an "interpretive community").

318 Beebe, supra note 24 , at 648 .

319337 F.3d 1024, 1030 (9th Cir. 2003).

320 The Anti-Cybersquatting Consumer Protection Act, 15 U.S.C. $\$ 1125$ (d) (2000), authorizes relief under certain circumstances based on an in rem filing against the offending domain name. See 15 U.S.C. $\$ 1125$ (d)(2)(A) (2000).

321 See Xuan-Thao N. Nguyen, Commercial Law Collides with Cyberspace: The Trouble with Perfection-Insecurity Interests in the New Corporate Asset, 59 WASH. \& LEE L. REV. 37 (2002) (evaluating two scenarios for perfecting security interests in domain names).

${ }_{322}$ Network Solutions, Inc. v. Umbro Int'l, Inc., 529 S.E.2d 80 (Va. 2000). The result in Umbro is criticized in Juliet M. Moringiello, Seizing Domain Names To Enforce Judgments: Looking Back to Look To the Future, 72 U. CIN. L. REV. 95 (2003) (noting commercial importance of treating domain names as property-like assets).

${ }^{323}$ U.C.C. § 1-201(37) (2001); see PSINet, Inc. v. Cisco Sys. Capital Corp. (In re PSINet, Inc.), 271 B.R. 1, $43-46$ (Bankr. S.D.N.Y. 2001); C.F. Garcia Enters., Inc. v. Enter. Ford Tractor, Inc., 480 S.E.2d 497, 499 (Va. 1997).

324 See, e.g., Micro Data Base Sys., Inc. v. Dharma Sys., Inc., 148 F.3d 649, 654 (7th Cir. 
product is a "good" rather than a "service," despite the intangibility of the program and the fact that the economic value of the deal lies in that intangible "thing," rather than in any tangible medium, such as a disk or tape, because commercial and consumer markets have come to treat it as such. The now-failed enterprise to encode the license-asthing principle ${ }^{325}$ in a new Article of the U.C.C. and later in the Uniform Commercial Information Transactions Act (UCITA) was premised on the idea that the licensing model was so well established as a market and cognitive phenomenon that it satisfied a Llewellyn-ish standard for statutory codification. ${ }^{326}$ The failure of the codification movement was not so much a failure of the thing-by-practice model as it was a failure to show that both producers and users of computer programs recognized the practice.

In many respects, the patent doctrines of repair and reconstruction, first sale, and implied license and exhaustion, discussed earlier in connection with thing-by-nature and thing-by-contract, dovetail with the thing-by-practice approach. One important early strand of first sale reasoning in patent and copyright cases concerned whether the patentee or the copyright owner had received a fair "reward" in exchange for the patented or copyrighted item. ${ }^{327}$ If so, the item passed into the stream of commerce, and the rights holder was not entitled to make any further claims regarding reuse or resale of that item. The thingness of the item in these cases, that is, the line between what belonged in a sense to the rights holder and what belonged to the consumer, was determined by the market as a whole, regardless of the nominal form of the transaction, and regardless of whether or not the transfer was voluntary. The Court wrote in 1942:

[T]his Court has quite consistently refused to allow the form into which the parties chose to cast the transaction to govern. The test has been whether or

1998); Advent Sys. Ltd. v. Unisys Corp., 925 F.2d 670, 675 (3d Cir. 1991); ePresence, Inc. v. Evolve Software, Inc., 190 F. Supp. 2d 159, 163 (D. Mass. 2002); Olcott Int'l \& Co. v. Micro Data Base Sys., Inc., 793 N.E.2d 1063, 1071 (Ind. Ct. App. 2003).

325 See supra notes 247-48 and accompanying text.

326 See Lorin Brennan, Why Article 2 Cannot Apply to Software Transactions, 38 DUQ. L. REV. 459 (2000); Nimmer, supra note 173.

${ }^{327}$ See, e.g., United States v. Masonite Corp., 316 U.S. 265, 278 (1942); Adams v. Burke, 84 U.S. (17 Wall.) 453, 456 (1873); Mitchell v. Hawley, 83 U.S. (16 Wall.) 544, 547 (1872); Keeler v. Standard Folding Bed Co., 157 U.S. 659, 663 (1895); United States v. Univis Lens Co., 316 U.S. 241, 251 (1942). A similar justification has been offered for copyright's first sale principle. See, e.g., Platt \& Munk Co. v. Republic Graphics, Inc., 315 F.2d 847, 854 (2d Cir. 1963); Lantern Press, Inc. v. Am. Publishers Co., 419 F. Supp. 1267, 1272-73 (E.D.N.Y. 1976); Burke \& Van Heusen, Inc. v. Arrow Drug, Inc., 233 F. Supp. 881, 884 (E.D. Pa. 1964). 
not there has been such a disposition of the article that it may fairly be said that the patentee has received his reward for the use of the article. ${ }^{328}$

The mere existence of the reward does not govern, but rather whether it was "fair"- a primitive reading of market processes. ${ }^{329}$

More recently, "fair reward" arguments have given way to different justifications, still based on thing-by-practice. In copyright law, for example, there is the doctrine of first sale, codified in 17 U.S.C. $\S 109,{ }^{330}$ which immunizes owners of lawfully made copies of copyrighted works from claims that they distributed or redistributed those copies without the copyright owner's permission. The doctrine may be said to deal with anticompetitive concerns and consumer interests, ${ }^{331}$ but it has been defended recently by the Copyright Office on the ground that it exists merely to give effect to the traditional distinction between copyrighted works and objects that embody them. ${ }^{332}$ There is the notion of implied license, which enables the use of things that we receive on the ordinary understanding that use is intended. ${ }^{333}$ "Useful articles" receive special treatment when questions of copyrightability arise; tangible dimensions of expressive objects are not foreclosed from copyright protection entirely, but the rules are set up to limit the scope of copyright to expression that can somehow be "separated"-either physically or conceptually-from objects. ${ }^{334}$ The

328 Masonite, 316 U.S. at 278.

329 The role of the market as an aggregator and provider of "justice" for things overlaps here with the place of the market as defined by the "normal" consumption and use of objects. See supra notes 104-09 and accompanying text (describing role of "normal" commercial activity in constructing rule against restraints on alienation).

33017 U.S.C. $\$ 109$ (a) (2000). The first sale "right," in truth a defense to a claim of infringement of the distribution right, does not extend to rentals of computer programs or phonorecords. See id. $\$ 109$ (b). Codification of the distinction between the work of authorship and its tangible form is a closely related cousin. See id. $\S 202$.

331 See R. Anthony Reese, The First Sale Doctrine in the Era of Digital Networks, 44 B.C. L. REV. 577 (2003) (focusing on affordability and availability policies underlying the doctrine).

332 See UNITED STATES COPYRIGHT OFFICE, DMCA SECTION 104 REPORT 78-92 (2001) (concluding, among other thing, that changes to the information landscape did not mandate development of a right of "digital first sale" to protect consumer expectations in electronic settings). On the wisdom of borrowing a digital first sale right from the analog world, compare Ann Bartow, Electrifying Copyright Norms and Making Cyberspace More Like a Book, 48 VILL. L. REV. 13 (2003) (urging emulation of offline norms in rules for online behavior), with Mark A. Lemley \& R. Anthony Reese, Reducing Digital Copyright Without Restricting Innovation, 56 STAN. L. REV. 1345, 1374 n.112 (2004) (questioning wisdom of that approach).

333 The paradigmatic implied license decision is Effects Associates, Inc. v. Cohen, 908 F.2d 555 (9th Cir. 1990). In isolation, the doctrine has the flavor of thing-by-contract. As some have attempted to extend it, however, its thing-by-practice character becomes clear. See Robert W. Gomulkiewicz, De-Bugging Open Source Software Licensing, 64 U. PITT. L. REV. 75,85 n.73 (2002) ("It may not be a first sale when someone simply gives a copyrighted work for free with no explanation: the recipient may simply receive an implied license.").

334 See Brandir Int'l, Inc. v. Cascade Pac. Lumber Co., 834 F.2d 1142 (2d Cir. 1987); Kar- 
substance of the distinction may be based on how works and objects are perceived by the marketplace ${ }^{335}$ or on how they are used, ${ }^{336}$ but in either case, copyright reaches limits imposed by economic or social practice rather than by nature or design. ${ }^{337}$

First sale and exhaustion cases also demonstrate that the thing-aspractice model is weakest where the practice is poorly understood or is changing. Express limitations on repair and disposal of the thing, and copyright-style protection for the form of the thing rather than merely the expression, are controversial precisely because they conflict so clearly with apparently settled expectations regarding thingness. Litigation over so-called tethered products embodying intellectual property interests (so called because they are designed to be experienced only in conjunction with specified counterpart devices) has focused precisely on the extent to which their use is governed by existing consumer expectations, or by the dictates of the manufacturer. In Universal City Studios v. Corley, ${ }^{338}$ the Second Circuit upheld application of the anticircumvention provisions of the Digital Millennium Copyright Act (DMCA) to a defendant who "trafficked" in software that enabled owners of DVDs to watch their discs (including lawfully purchased discs) on machines other than DVD players licensed by film producers. By contrast, in Chamberlain Group v. Skylink Technologies, ${ }^{339}$ the Federal Circuit refused to interpret the DMCA so as to forbid a consumer from making unfettered use of a software-equipped garage door opener that the consumer had bought and paid for. Notwithstanding that the consumer's use of an aftermarket remote control necessitated a form of electronic access to the original door system's computer code, the court wrote: "Consumers who purchase a product containing a copy of embedded software have the inherent legal right to use that copy of the software. What the law authorizes, Chamberlain cannot revoke. ${ }^{340}$ The manufacturer and plaintiff, Chamberlain, was not

jala, supra note 128 , at $448-49,452$.

335 See Alfred C. Yen, Copyright Opinions and Aesthetic Theory, 71 S. CAL. L. REV. 247, 252-53 (1998) (outlining different approaches to defining art).

336 See Karjala, supra note 128 , at $448-58$.

337 Brandir International, which adopted Robert Denicola's "perspective of the artist" standard for the conceptual separability of aesthetic from utilitarian dimensions of useful objects, is the exception that proves the rule, since it necessarily anticipates that artists seeking protection for aesthetics in useful objects must prove that their design choices were themselves artistic, measured against some relevant artistic or design community. Brandir Int'l, 834 F.2d at $1145-46$.

338273 F.3d 429 (2d Cir. 2001).

339381 F.3d 1178 (Fed. Cir. 2004).

340 Id. at 1202. 
permitted to change the character of a thing already subject to an established set of consumer expectations.

The precise source of those expectations, however, remains unarticulated. It is difficult to imagine that universal garage door openers or DVDs have been available and in use for so long that all of American society shares a cognizable sense of what we ought to be able to do with them. We are left with the intuitive importance of the physical thing. ${ }^{341}$ Joseph Liu notes that the copyright rules dealing with tangibility in copyright have an important salutary effect, balancing producer, consumer, and reuser interests. ${ }^{342}$ In conception and design, however, the rules simply reflect traditional understandings of the law. Things are special in copyright, as they are elsewhere in law, because of how we experience them. But we do not know precisely why. $^{343}$

${ }^{341}$ See Joseph P. Liu, Owning Digital Copies: Copyright Law and the Incidents of Copy Ownership, 42 WM. \& MARY L. REV. 1245, 1301 (2001) ("Copyright law structures itself around ... understandings about the physical environment and physical property ownership.").

${ }^{342}$ See id. at 1336-37. Carla Hesse's intellectual history of copyright points out that what we now recognize as the basis for the consumer's right in the lawful copy originated as a distinction between the form of the author's work and the work itself, as a basis for the author's right. Carla Hesse, The Rise of Intellectual Property, 700 B.C.-A.D. 2000: An Idea in the Balance, 131 DaEDALus 26, 35 (2002); see also Martha Woodmansee, The Genius and the Copyright: Economic and Legal Conditions of the Emergence of the 'Author,' 17 EIGHTEENTH CENTURY STUD. 425 (1984) (tracing the form/expression distinction to Fichte and from Fichte back to Kant). What we experience today as thing-by-practice had its philosophical origins in thing-by-nature.

343 American Studies scholars have argued that "the book" constitutes a distinctive, even exceptional, physical and economic commodity, though without really explaining why this is so. This view treats the expansion of intellectual property interests in American law during the nineteenth century as vindication of interests in the physical, rather than as vindication of interests in the intangible. See JOSEPH LOEWENSTEIN, THE AUTHOR'S DUE: PRINTING AND THE PREHISTORY OF COPYRIGHT (2002) (arguing that the culture of books and the idea of the author are intimately tied to the physical act of publishing); JOSEPH LOEWENSTEIN, BEN JONSON AND POSSESSIVE AUTHORSHIP (2002) (finding that possessive ownership was tied historically to printing and the accountability that it brought to authorship); MEREDITH L. MCGILL, AMERICAN LITERATURE AND THE CULTURE OF REPRINTING, 1834-1853 (2003) (describing going-into-print in America as the beginning of the struggle between individual rights and social demands). "In the American debate over literary property, both sides define the text as an extraordinary commodity, an exception to the laws that govern ordinary things." Meredith L. McGill, The Matter of the Text: Commerce, Print Culture and the Authority of the State in American Copyright Law, 9 AM. LITERARY Hist. 21, 22 (1997). Wheaton v. Peters, as McGill points out, firmly established in American copyright law the distinction between the "thing" that consisted of the author's original work and that remained his property under the common law, on the one hand, and the printed versions of that work, on the other hand, "things" whose publication triggered the interest of the civic sphere and the application of statutory copyright. Id. at $41-42$. On the counterpart English context of book manufacturing, see ADRIAN JOHNS, THE NATURE OF THE BOOK: PRINT \& KNOWLEDGE IN THE MAKING 2-5 (1998) (arguing that the development of the printed book was not inevitable; rather, the printed book is the product of a "complex set of social and technological processes").

Putting "the book" front and center in American copyright contrasts with the critical view of copyright as the story of the "romantic author" whose interest happens to be vindicated via commodified texts. The canonical version of the theory is MARK ROSE, AUTHORS AND 
Much as these examples illustrate how thing-by-practice can serve as a useful and broadly accepted mediator of conflicts between social evolution and overly rigid legal forms, both the forms and practices of modern technology challenge the model. Form offers a clear challenge. Despite the application of Article 2 to transactions in computer software, computer programs and other digital products cannot be appreciated readily as "things" like books, machines, or anything else.

To what extent does it really make sense to evaluate and rely on social or cultural practices, or even markets, with respect to such rapidly changing technology? Metaphors may be helpful here, in encouraging courts to recognize the consumer-created thingness of digital objects. ${ }^{344}$ Metaphors that are poorly applied, however, may mislead. ${ }^{345}$ It is not clear that thing-by-practice is sufficiently robust to handle the complexity and dynamism of modern things. ${ }^{346}$

Instability and manipulability of markets and practices creates a second challenge. Thing-by-practice raises difficult empirical questions concerning knowing what practices are and knowing what practices count. For example, in the software developer community and perhaps beyond, the configurability of business practices has created a contest over the proper source of practice for the thing-model. Software developers have spent the last thirty years trying to persuade consumers to accept the inevitability (as well as the wisdom) of the licensing paradigm for computer software. Glen Robinson has argued that enough time has passed to dispel any lingering notion that consumer expectations might justify a presumption that software is in fact being sold. ${ }^{347}$ I have disagreed, ${ }^{348}$ though we frame the question in different terms. ${ }^{349}$ Does the modern marketplace permit producers to capture thing-by-practice and recast it as thing-by-design? Perhaps. ${ }^{350}$ A similar conflict may be at work in differing perspectives on how to analyze peer-to-peer software applications for file sharing.

OWNERS: THE INVENTION OF COPYRIGHT (1993).

344 See Michael J. Madison, Rights of Access and the Shape of the Internet, 44 B.C. L. REV. 433, 437 (2003) (arguing that "[t]he Internet-as-place metaphor should be interpreted doctrinally in ways that are consistent with user experience of Internet, rather than via formal, abstract, and absolutist notions of 'property"').

345 See Hunter, supra note 10 (critiquing the cyberspace-as-place metaphor); Lemley, supra note 10 (same).

346 See supra notes 41-66 and accompanying text.

347 See Robinson, supra note 38 , at 1467.

348 See Madison, supra note 172, at 308-16.

${ }^{349}$ Robinson looks at the individual consumer; I look at the social practice.

350 The merchandising right cases in trademark law are another example of this sort of recasting. See supra note 24 and accompanying text. 
Should the law focus on social practices that treat this software itself as a "thing" comparable to the thingness of the Sony Betamax? ? $^{351}$ Or should the law focus on the practices that surround the copyrighted things-works of authorship - that flow through file sharing networks without the permission of copyright owners? $?^{352}$

\section{THING-BY-POLICY}

The fifth and final alternative, then, avoids these conflicts, preferring to use thingness simply and explicitly as a proxy for policy goals, rather than as a starting point for an inquiry into the thingness of the thing. This model returns explicitly to the Realist and relational premise that this Article promised initially to distinguish. We may like to think in terms of a world of things, whether or not the world initially presents itself to us that way, ${ }^{353}$ but the legal system may not allow thingness simply to be. Law regulates, and as regulator the law is pleased to take advantage of our intuitive thing-making cognitive apparatus. But in the end, legal things may be nothing more (or less) than constructs of values, individual and communal. Lloyd Weinreb has criticized the call for identifying "what sort of thing something is" as inferior to dealing with the relevant interests as stake. ${ }^{354}$ Felix Cohen called legal things metaphors that were "transcendental nonsense" when taken seriously in themselves. ${ }^{355}$ Outside of law, and speaking not of legal fictions but of material things themselves, cultural critics of the same era lamented (and others celebrated) the disappearance of the authenticity of the material wrought by modern technology. ${ }^{356}$ Contemporary critical theory descends from the same position, both in $\mathrm{law}^{357}$ and otherwise. ${ }^{358}$ It has been adopted whole-

351 See, e.g., supra note 30 and accompanying text.

352 See supra note 316 and accompanying text.

353 Moreover, we may prefer to think in terms of things that we have, rather than in terms of things that we do not have. See Russell Korobkin, The Endowment Effect and Legal Analysis, 97 Nw. U. L. REV. 1227, 1261-62, 1268 (2003) (noting that what psychologists term the "endowment effect"-that we value what we have over objectively equivalent things that we do not have-derives partly from physical possession and partly from constructed preferences for things); Rose, supra note 307 (exploring the common law maxim, "first possession is the root of title").

354 Weinreb, supra note 126 , at 1254 . He notes that much of copyright is founded on an uncritical, conventional account of "the nature of things."

355 Cohen, supra note 66 , at 812 .

356 See BENJAMIN, supra note 13.

357 See Grey, supra note 140; Vandevelde, supra note 26.

358 See FOUCAULT, supra note 279, at 47-49 (describing the disappearance of things entirely, in favor discourse); JEAN BAUDRILLARD, From the System to the Destiny of Objects, in THE ECSTASY OF COMMUNICATION (Sylvere Lotringer ed., Bernard Schutzee \& Caroline Schutzee trans., 1988) (1987) (asserting the totalizing dominance of the subject and the disappearance of the object). 
sale by much of the discipline of law and economics. ${ }^{359}$ I call this final model "thing-by-policy."

The three core intellectual property doctrines-copyright, patent, and trademark law-are the first and easiest places to see this regulatory perspective at work. ${ }^{360}$ All three doctrines have as their essential concern the intangible thingness of the copyrighted work, the patented invention, and the distinctive "mark." Their boundaries are determined in a variety of ways, many of which are unambiguously constructs of relevant policies. In copyright, this is done typically only ex post, during litigation to enforce the copyright, but the scope of the work - the thing created by the author-is defined by the law nonetheless, by the distinction between unprotectible "idea" and protectable "expression,", by the doctrine of "substantial similarity,",362 and by the concept that authorial works must be protected in a "tangible medium of expression" before protection will attach. ${ }^{363}$ In patent law, the law supplies definitions both ex ante and ex post (rules defining patentable subject matter and patentability in the particular case-

359 Entitlements are conventionally defined in relational terms, in that they might be characterized by liability rules, property rules, or inalienability rules. See Jules L. Coleman \& Jody Kraus, Rethinking the Theory of Legal Rights, 95 YALE L.J. 1335 (1986); Guido Calabresi \& A. Douglas Melamed, Property Rules, Liability Rules, and Inalienability: One View of the Cathedral, 85 HARV. L. REV. 1089 (1972).

${ }^{360}$ Calling patents, copyrights, and trademarks "regulatory" deliberately evokes the extensive literature debating the nature of the doctrines as regulatory or proprietary. See, e.g., JESSICA LITMAN, DIGITAL COPYRIGHT 171-82 (2001) (arguing that copyright is properly conceptualized as an unfair competition regime); Joseph P. Liu, Regulatory Copyright, 83 N.C. L. REV. 87 (2004) (arguing that copyright law manifests a trend away from a property rights model, toward a regulatory model).

36117 U.S.C. $\$ 102(a)$, (b) (2000) (distinguishing original works of authorship from processes and methods of operation); Baker v. Selden, 101 U.S. 99 (1879) (seminal case understood as distinguishing idea from expression). Some courts have been particularly explicit in recognizing this character of the inquiry:

What is basically at stake is the extent of the copyright owner's monopoly-from how large an area of activity did Congress intend to allow the copyright owner to exclude others? We think the production of jeweled bee pins is a larger private preserve than Congress intended to be set aside in the public market without a patent. A jeweled bee pin is therefore an "idea" that defendants were free to copy.

Herbert Rosenthal Jewelry Corp. v. Kalpakian, 446 F.2d 738, 742 (9th Cir. 1971).

Thing-by-policy is not exclusively a modern device. Under the 1790 Copyright Act, which extended copyright protection to books, a district court determined that a market (price) circular was not the subject of copyright protection because according to copyright policy, it was not a book: "The term 'science' cannot, with any propriety, be applied to a work of so fluctuating and fugitive a form as that of a newspaper or price current, the subject-matter of which is daily changing, and is of mere temporary use." Clayton v. Stone, 5 F. Cas. 999, 1003 (S.D.N.Y. 1829) (No. 2,872).

362 See Computer Assocs. Int'l, Inc. v. Altai, Inc., 982 F.2d 693 (2d Cir. 1992) (applying an "abstraction-filtration-analysis" framework to substantial similarity questions involving computer programs, in order to give proper scope to role of the public domain).

363 See Williams Elecs., Inc. v. Artic Int'l, Inc., 685 F.2d 870 (3d Cir. 1982) (holding that video game display was "fixed" for copyright purposes because it meets the statutory standard of being perceptible for more than a transitory period of time). 
novelty, nonobviousness, enablement, written description, and so forth $^{364}$ ) and solely ex post, during infringement litigation (the process of claim construction, the "all elements" rule for infringement, and the doctrine of equivalents). ${ }^{365}$ The structuring of the legal thingness of trademarks is similar. What "is" the mark is defined ex ante by limiting protection to "distinctive" marks and ex post by the "likelihood of confusion" standard for infringement.

The core structures of intellectual property law, in other words, can be recharacterized in terms of the search for things, ${ }^{366}$ not because things themselves are the true foci of the law, but because the law expresses its policies-legal exclusivity that creates incentives to be creative and innovative; protection of fair competition in the marketplace-through things. Two points bear extra emphasis. One is that the search for the relevant thing consists of the search for the underlying phenomena-in-fact (the "work," the "invention," and the "mark") rather than the search for the legal phenomena (the copyright, the patent, the trademark). At the end of the analysis, "factual" and "legal" things are identical; once rules governing protection and infringement are applied, the legal right is coextensive with what the right owner in fact created, invented, or made distinctive. ${ }^{367}$ Two is that this process of identifying the thing, which is intuitively a proprietary concept, is itself regulatory. Any conflict between propertybased and regulatory constructions of intellectual property systems may be overstated. Copyright, patent, and trademark inescapably share characteristics of both.

Intellectual property doctrines that raise different problems of scope, because they implicate competition concerns that surround tangible things themselves, likewise can be understood in the thingby-policy framework. Courts have held that copying a copyrighted

364 The requirement that the patent claim be supported by a written description of the invention has been enhanced precisely in areas, such as bioscience inventions, where public policy concerns are especially pronounced. See Univ. of Rochester v. G.D. Searle \& Co., 358 F.3d 916 (Fed. Cir.), cert. denied, 543 U.S. 1015 (2004); see also Univ. of Rochester v. G.D. Searle \& Co., 375 F.3d 1303, 1304-05 (Fed. Cir. 2004) (Newman, J., dissenting from denial of rehearing en banc) (arguing that Federal Circuit should address general applicability of written description requirement en banc because of general policy concerns).

365 See Wamer-Jenkinson Co. v. Hilton Davis Chem. Co., 520 U.S. 17, 29 (1997) (confirming applicability of all-elements rule to doctrine of equivalents analysis, as a balance between notice function of patent claims and the interest of the patentee).

${ }^{366} C f$. Long, supra note 4, at 471-95 (arguing that information costs represent the right metric for determining optimal thingness in intellectual property doctrines).

367 Wendy Gordon therefore characterizes copyright and patent rights as in rem rights. Wendy J. Gordon, An Inquiry into the Merits of Copyright: The Challenges of Consistency, Consent, and Encouragement Theory, 41 STAN. L. REV. 1343, 1378-84 (1989). But see Jessica Litman, The Public Domain, 39 EMORY L.J. 965, $971-72$ (1990) (expressing skepticism at the capacity of copyright law to cabin thingness). 
computer program in order to "reverse engineer" it is permitted in order to identify its non-protected "ideas," and they point to policy justifications as reasons for not respecting the found thingness of the work. As the court noted in Sega Enterprises Ltd. v. Accolade, Inc. ${ }^{368}$ affirming that such reverse engineering constitutes fair use, "[A]n attempt to monopolize the market by making it impossible for others to compete runs counter to the statutory purpose of promoting creative expression and cannot constitute a strong equitable basis for resisting the invocation of the fair use doctrine." commerce" doctrine discussed in terms of thing-by-practice ${ }^{370}$ is equally a manifestation of policy arguments. Sale of the "staple item" is treated as sale of a thing that lies beyond the reach of copyright, because of the harm to competition in markets for things that would follow from the opposite result. "The staple article of commerce doctrine must strike a balance between a copyright holder's legitimate demand for effective - not merely symbolic - protection of the statutory monopoly, and the rights of others freely to engage in substantially unrelated areas of commerce."371

That balance, in other words, gives us the thing that we know as the VCR. Cases arising under the DMCA addressing tethered goods $^{372}$ (DVDs linked to DVD players, computer sound files linked to specified media players, print cartridges linked to computer printers, video games linked to specified virtual game environments) test the policy justifications for the tethers by framing disputes in terms of the things being made and used. In Lexmark International $v$. Static Control Components, ${ }^{373}$ the court's ruling for the defendant, a manufacturer of computer chips that were used ultimately by consumers to bypass technology that prevented consumers from using nonLexmark print cartridges with Lexmark printers, was reinforced by the court's sense that Congress, expressing its concern for consumer protection in the context of the DMCA, could not have intended this result. For policy reasons, in other words, a printer remains a printer. It cannot be converted to a limited use printer via software sleight-ofhand.

Patent law offers the same insight, but it does so in cases that reverse the sensibility about tangible and the intangible that informs the copyright and DMCA cases. Is a computer program sufficiently

\footnotetext{
${ }^{368} 977$ F.2d 1510 (9th Cir. 1992).

${ }^{369} \mathrm{Id}$. at $1523-24$.

370 See supra notes 314-16 and accompanying text.

${ }^{371}$ Sony Corp. of Am. v. Universal City Studios, Inc., 464 U.S. 417, 442 (1984).

372 See supra notes 31-53 and accompanying text.

373387 F.3d 522, 549 (6th Cir. 2004) (quoting the statement of Rep. Bliley).
} 
concrete to qualify as a patentable thing? Patenting the abstract mathematics that characterize a program might be disallowed because exclusive control over what today might be called a "platform" resource-a foundational technology, on which later inventions depend-would interfere with later innovation. "Phenomena of nature, though just discovered, mental processes, and abstract intellectual concepts are not patentable, as they are the basic tools of scientific and technological work." 374 Or the competitive implications of patenting abstractions may be less severe. The invention is thus a "thing" rather than an abstraction, and a patent may be acceptable. ${ }^{375}$

Trademark law presents some of the most difficult doctrinal questions, since trademarks are not supposed to be "things" at all. ${ }^{376}$ There is, formally, no such thing as a trademark right "in gross," divorced from the sale of a good or provision of a service ${ }^{377}$ and "merchandising right" cases, in which the plaintiff's mark and the plaintiff's merchandise are effectively one and the same (such as a t-shirt with a Nike logo), have been heavily criticized by scholars. ${ }^{378}$ Firms may attempt to protect products themselves using trademark law, efforts that are limited on policy grounds by concerns for competitive markets and on doctrinal grounds, expressing that policy, by trademark's functionality doctrine. Design features of a product may be (intangible) trademark things, unless competitive concerns dictate that they be treated as (tangible) nontrademark things. ${ }^{379}$ Trademark-as-thing in

374 Gottschalk v. Benson, 409 U.S. 63, 67 (1972).

375 See State St. Bank \& Trust Co. v. Signature Fin. Group, Inc., 149 F.3d 1368, 1376-77 (Fed. Cir. 1998) (rejecting district court's concern for competition in the marketplace as a basis for the business method exception to patentable subject matter).

376 But see Stephen L. Carter, Does It Matter Whether Intellectual Property Is Property?, 68 CHI.-KENT L. REV. 715, 720-21 (1993) (considering the benefits of treating trademarks as property).

377 See Vittoria N. Am. L.L.C. v. Euro-Asia Imps., Inc., 278 F.3d 1076 (10th Cir. 2001). Courts will often find ways around the formal rule, particularly when trademarks are used as collateral. This is thing-by-practice as much as thing-by-policy. See, e.g., Patterson Labs., Inc. v. Roman Cleanser Co. (In re Roman Cleanser Co.), 802 F.2d 207, 208-09 (6th Cir. 1986); Money Store v. Harriscorp Fin., Inc., 689 F.2d 666, 676-78 (7th Cir. 1982).

378 See Dogan \& Lemley, supra note 24; Litman, supra note 24.

379 Kellogg Co. v. Nat'l Biscuit Co., 305 U.S. 111 , 120-22 (1938) (articulating early form of trademark law's "functionality" doctrine by linking it to the right to copy an article that is the subject of an expired patent). The modern form of the functionality doctrine depends largely on thing-by-nature, see supra note 95, and partly on thing-by-policy. See Qualitex Co. v. Jacobson Prods. Co., Inc., 514 U.S. 159, 164 (1995) ("The functionality doctrine prevents trademark law, which seeks to promote competition by protecting a firm's reputation, from instead inhibiting legitimate competition by allowing a producer to control a useful product feature."); TrafFix Devices, Inc. v. Mktg. Displays, Inc., 532 U.S. 23, 29 (2001) ("[C]opying is not always discouraged or disfavored by the laws which preserve our competitive economy."); Abercrombie \& Fitch Stores, Inc. v. Am. Eagle Outfitters, Inc., 280 F.3d 619, 630-31 (6th Cir. 2002) (noting that the kind of "thing" that can constitute trade dress must depend, ultimately, on trademark law's goal of protecting distinctiveness and avoiding consumer confusion). 
these contexts is comprehensible in policy terms even if the line here is, at times, almost impossibly imprecise. ${ }^{380}$

Thing-by-policy is hardly limited to intellectual property cases. The question of thingness has been consciously manipulated by courts in order to police subject matter boundaries in other areas. The law of rescission of contracts for mutual mistake depends in part on whether the contracting parties correctly perceived the character of the "thing" that was the subject of the deal, a standard that courts once took literally $^{381}$ but today treat metaphorically, as a proxy for the allocation of risk. ${ }^{382}$ Products liability doctrine based on defective design is framed today around a policy-driven risk/utility calculus, rather than the traditional consumer expectations principle. ${ }^{383}$

Elsewhere, thingness mediates policy concerns where traditional doctrine otherwise leaves courts without good tools. In People v. $K w o k,{ }^{384}$ a California appellate court upheld a burglary conviction where the defendant had a key made to fit the door of the victim's house. The homeowner's interest in exclusive control over access to the home justified treating the defendant's actions as "theft" of property, even though the defendant only temporarily dispossessed the victim of the lock to her door so that the key could be made. ${ }^{385}$ In State v. Nelson, ${ }^{386}$ the defendant borrowed photographs of the victim, copied them, and returned the photographs. The Supreme Court of New Hampshire upheld a conviction for theft. The court's reasoning was similar to that of the court in Kwok; the victim was not permanently deprived of any physical thing, but was treated as if she were. According to the court, she had been deprived of that which is "[i]ntegral to ownership, ... the right to exclude others from possessing, using and enjoying a particular item of property." 387 An insurance

380 Graeme Dinwoodie criticizes ontological approaches to trademarks and urges an approach that more explicitly grounds trademark thingness in policy objectives. Graeme B. Dinwoodie, The Death of Ontology: A Teleological Approach to Trademark Law, 84 lowA L. REV. 611 (1999).

381 See Sherwood v. Walker, 33 N.W. 919, 923 (Mich. 1887) (conceming a seller who desired to rescind a contract for sale of the pregnant cow Rose $2 \mathrm{~d}$ of Aberlone, "the mistake [as to her pregnancy] was not of the mere quality of the animal, but went to the very nature of the thing").

382 See John D. Calamari \& Joseph M. Perillo, Calamari and Perillo on CONTRACTS (5th ed. 2003) $\$ 9.26$, at 365-66.

383 E.g., Jay M. Feinman, Un-Making Law: The Classical Revival in the Common Law, 28 SEATTLE U. L. REV. 1, 37-38 (2004) (describing the move away from consumer expectations as the basis of design defect liability, and toward the risk/utility approach); John W. Wade, On the Nature of Strict Tort Liability for Products, 44 MiSS. L.J. 825, 837-38 (1973).

38475 Cal. Rptr. 2d 40 (Cal. App. 1998).

385 Id. at 49.

386842 A.2d 83 (N.H. 2004).

${ }^{387}$ Id. at 86. 
company was relieved of its duty of defense under a general liability policy when computer software distributed by the insured, America Online, was alleged by consumers to have damaged their computers. The policy covered "physical damage to tangible property." After a lengthy and largely unnecessary recitation of the differences between "hardware" and "software," the court got to the heart of the matter. Damage to the operating systems of consumer computers did not constitute damage to relevant tangible "things" because under the opposite interpretation, "St. Paul's risk would have been much greater and the premiums for such a policy undoubtedly would have been more expensive."388 Whether a computer server constitutes a thing-like "chattel" for legal purposes may depend entirely on the underlying policy concerns at stake in the litigation. An Internet Service Provider (ISP) was held not liable for "negligent entrustment of chattels" when one of its customers used ISP resources to spy on naked athletes in locker rooms, because the ISP's services are used lawfully by the vast majority of its customers. ${ }^{389}$ "[T] $[$ hese are lawful commodities whose uses overwhelmingly are socially productive. That Web hosting services likewise may be used to carry out illegal activities does not justify condemning their provision whenever a given customer turns out to be crooked. ${ }^{390}$ A computer server is a chattel, however, when someone is trying to access data stored on that server, without the permission of the server's owner. In that case, there is liability for "trespass to chattel," though the real harm, as the court acknowledged in $e$ Bay $v$. Bidder's Edge, ${ }^{391}$ is policy-based. "If BE's activity is allowed to continue unchecked, it would encourage other auction aggregators to engage in similar recursive searching of the eBay system such that eBay would suffer irreparable harm from reduced system performance, system unavailability, or data losses." 392

The final and perhaps most elaborate illustration of thing-bypolicy comes from the antitrust area. What is an operating system for a computer? The answer turns out to depend on economics and public policy, not computer science. In the opinion that has become known

388 Am. Online, Inc. v. St. Paul Mercury Ins. Co., 347 F.3d 89, 98 (4th Cir. 2003). A strongly worded dissent noted that other courts have divided on the issue and that the tenuous distinction between "data" and "hardware" did not justify dismissing the duty to defend claim at the pleading stage. Id. at 99-103 (Traxler, J., dissenting). The majority, in other words, justified a policy-based distinction by resorting to its construction of thingness. The dissent relied on a different construction of thingness.

389 See Doe v. GTE Corp., 347 F.3d 655, 660-62 (7th Cir. 2003).

390 Id. at 659.

391100 F. Supp. 2d 1058 (N.D. Cal. 2000).

392 Id. at 1066. 
as "Microsoft III,"393 the Court of Appeals for the District of Columbia Circuit analyzed whether Microsoft Corporation violated the Sherman Act by, among other things, "bundling" its Internet Explorer browser software with its Windows operating system-distributing what had previously been believed to be two computer programs as a single, integrated program. The established law of "tying" holds that tying two products together in a single transaction, so that consumers who want to buy one product are forced to accept a second, is per se unlawful. ${ }^{394}$ The definition of "product" is given in economic terms, primarily by consumer demand. "[A] tying arrangement cannot exist unless two separate product markets have been linked." 395 An unlawful tie occurs when purchases of product $A$, as measured by consumer demand, are tied to product $B$.

Did Microsoft unlawfully force purchasers of Windows to accept copies of Internet Explorer, when the natural result of the combination would be induce some substantial number of computer users to rely on Internet Explorer to the exclusion of what was then its principal competition-the Netscape Navigator browser? The answer depended on whether the Windows operating system, excluding Web browser functionality, constituted an independent product. Alternatively, perhaps the "operating system" included browser functionality, in which case no tying claim would lie. More concisely, what is an operating system?

Rather than approach the question purely as a technological matter, or purely as an economic matter, the court fashioned a rule that was explicitly designed to balance Microsoft's legitimate interest in technological innovation, the fact that in many contexts consumers benefit from innovation and from software development processes that integrate formerly disparate functionalities into single products, and the public's interest in markets free from anticompetitive behavior. ${ }^{396}$ The court concluded, therefore, that a rule of reason approach would apply, rather than the per se rule against tying derived from Supreme Court precedent. It held that in a software tying case such as this one, the government bears the burden of showing that the harm to competition from integration of the programs outweighs its efficiency

393 United States v. Microsoft Corp. (Microsoft III), 253 F.3d 34 (D.C. Cir. 2001). Microsoft $I I$ is the name given to United States v. Microsofi Corp. (Microsoft II), 147 F.3d 935 (D.C. Cir. 1998), interpreting an earlier consent decree. Microsoft $I$ involved judicial review and approval of the consent decree. See United States v. Microsoft (Microsoft I), 56 F.3d 1448 (D.C. Cir. 1995).

394 See Jefferson Parish Hosp. Dist. v. Hyde, 466 U.S. 2 (1984); Eastman Kodak Co. v. Image Technical Servs., 504 U.S. 451 (1992).

395 Jefferson Parish, 466 U.S. at 21.

396 See Microsoft III, 253 F.3d at 84-95. 
benefits. ${ }^{397}$ What "is" an operating system is the product of a policy balance, taking into account both the designer's interest, consumers' interests, and broader public policy concerns. ${ }^{398}$

The flaws in the court's approach (in particular, its failure to consider the timing of the inquiry) should not overshadow the fact that the test fits comfortably alongside other policy-based standards for evaluating "predatory design," in which manufacturers allegedly design products specifically for anticompetitive purposes. In Microsoft $I I$, which involved a contempt proceeding against Microsoft for an alleged violation of an earlier antibundling consent decree, the Court of Appeals concluded that Microsoft, as the designer, was entitled to a presumption in its favor to the extent that Windows and Internet Explorer were combined as a result of "genuine technological integration." 399 "Genuine" integration meant that the result should be treated as one product, "regardless of whether elements of the integrated package are marketed separately." technological integration as any "product that combines functionalities ... in a way that offers advantages unavailable if the functionalities are bought separately and combined by the purchaser. ${ }^{, 401}$ The court set an extremely low bar for determining whether a product meets this test. All the defendant has to show is "a plausible claim" that the combination "brings some advantage."

In a related vein, the Areeda antitrust treatise would ask whether the practice of bundling is universal in the market? ? $^{403}$ If so, the bundle should be considered one product, not two. Universal or predominant bundling indicates that the bundle is, on balance, beneficial, since consumers prefer either the cost or the quality of the bundle over the freedom to choose independent products that unbundling provides.

397 Id. at $95-97$.

398 The court's reasoning can be compared with essentialist approaches of different sorts. Instead of suggesting that the court should identify "the" product, Mark Patterson argues that conflicts between intellectual property laws (which permit certain activities that could be characterized as anticompetitive) and antitrust law (which seeks to deter and punish anticompetitive behavior) can be managed by distinguishing between the intellectual property right itself and the product in which the right is embodied. Mark R. Patterson, When Is Property Intellectual? The Leveraging Problem, 73 S. CAL. L. REV. 1133, 1134-35 (2000). By contrast, Andrew Chin argues for a functionalist definition of "software product" based on the user's perspective. Andrew Chin, Decoding Microsoft: A First Principles Approach, 40 WAKE FOREST L. REV. 1, 16-17 (2005) (arguing that Microsoft should have been found liable for illegal tying, based on a "first principles" approach to what constitutes a software product, based on software engineering principles and antitnust market analysis).

399 Microsoft II, 147 F.3d at 948.

400 Id.

401 Id.

402 Id. at 950.

40310 Phillip E. AREeda \& Herbert Hovenkamp, ANTtTrust law: AN ANALysis of ANTITRUST PRINCIPLES \& THEIR APPLICATION II 1744 (2d ed. 2000). 
Judge Wald, dissenting in Microsoft II, would assign consumer interests greater weight in the policy balance than the rule of reason test of Microsoft III, making an "operating system" even more transparently a creature of the law than the Microsoft III panel admitted. ${ }^{404}$

In the European Union's (EU) subsequent investigation of Microsoft for the allegedly anticompetitive practice of bundling the Windows Media Player with the Windows operating system, the EU decision nominally identified the thingness of the operating system itself according to conventional economic measures-consumer demand $^{405}$ - though its remedy (requiring that Microsoft offer versions of Windows without the Media Player) shows clearly that the demand measure is explicitly a policy construct. ${ }^{406}$

Using thingness to balance technological innovation and consumer or public protection has been a frequent problem for computer system developers, ${ }^{407}$ but it is hardly limited to that environment. The point

404 Microsoft Il, 147 F.3d at 956-64 (Wald, J., dissenting). On mixing/matching "products" tests in bundling cases, see In re Data General Corp. Antitrust Litigation, 490 F. Supp. 1089 (N.D. Cal. 1980) (blending the manufacturer perspective, the consumer perspective, and other manufacturers' perspective).

405 See Commission Decision of 24.03.2004, supra note 166 (on appeal to the European Court of First Instance).

${ }^{406}$ See Picker, supra note 36; Ian Ayres \& Barry Nalebuff, Going Soft on Microsoft? The EU's Antitrust Case and Remedy, 2 THE ECONOMISTS' VOICE No. 2, Art. 4 (2005), available at http://www.bepress.com/ev/vol2/iss $2 /$ art 4 (arguing as a matter of competition policy that the EU antitrust remedy should have included not only an unbundling requirement (as it did) but also a must-carry provision, such that the Windows-plus-Windows Media Player combination must also include some rival media players). The EU approach is doctrinally closer to the traditional Jefferson Parish test for identifying separate products, focusing on how the market treats the products. See, e.g., United States v. Jerrold Elecs. Corp., 187 F. Supp. 545 (E.D. Pa. 1960) (noting additional factors relevant to determining consumer demand), aff'd, 365 U.S. 567 (1961). The fact that this inquiry is subordinate to competition policy is clear from refusal to deal cases such as Aspen Skiing Co. v. Aspen Highlands Skiing Corp., 472 U.S. 585 (1985) (finding that the "bundle" had to include access to the plaintiff's mountain; the product "thing" is constructed by law to include something that the defendant does not sell) and Verizon Commications, Inc. v. Law Offices of Curtis V. Trinko, L.L.P., 540 U.S. 398, 410 (2004) (holding that the plaintiff had no remedy under antitrust law for an incumbent local telephone exchange's violation of Telecommunications Act of 1996, which creates a duty to provide access to telephone network elements on an "unbundled" basis; the court found that the products here are unbundled by operation of law, and there was no antitnst violation in refusing to sell a thing that the defendant does not sell, but that is constructed by law for policy reasons).

407 See generally United States v. Microsoft Corp., No. CIV. A. 98-1232 (TPJ), CIV. A. 98-1233 (TPJ), 1998 WL 614485, at *8 (D.D.C. Sept. 14, 1998) (discussing litigation against IBM's retying CPUs of mainframe computers to peripheral devices). Cal. Computer Prods. v. Int'l Bus. Machs. Corp., 613 F.2d 727, 744 (9th Cir. 1979) (affirming IBM's right to integrate disk functions into CPUs). Cf. Berkey Photo, Inc. v. Eastman Kodak Co., 603 F.2d 263 (2d Cir. 1979) (refusing to impose duty on monopolist in camera market to disclose format changes to competitors). Predatory product design has also been referred to as "anticompetitive" product design, "predatory product innovation," or "technological predation." 3A AREEDA \& HOVENKAMP, supra note 403, II 776-781. For skepticism regarding predatory product design claims, see Joseph Gregory Sidak, Debunking Predatory Innovation, 83 COLUM. L. REv. 1121, 1142 (1983) (arguing that due to the difficulty of measuring the variables in predatory product design claims, courts and litigators risk "turn[ing] the courtroom into a colloquium on applied 
of ex post regulation of things is to account for public concerns that the design process presumably omits. Consumer protection is a cost that the producer does not internalize; regulation spreads that cost across society as a whole, enabling decision-makers to make discretionary judgments on society's behalf about the costs and benefits of regulation in the particular case. Thing-by-policy denaturalizes the thing. Automobile manufacturers have been accused of predation in failing to accommodate aftermarket sales of sound systems. In one early case, the court did not rule on the merits, holding that the plaintiff, who sought to hold Ford liable for its failure to design the dashboard of its cars so that the dash would accommodate aftermarket radios, had not proved that it was entitled to injunctive relief. ${ }^{408}$ The court in Town Sound and Custom Tops, Inc. v. Chrysler Motors Corp. ${ }^{409}$ addressed the situation directly, holding that Chrysler could not be held liable for "bundling" substandard car stereos with its cars. Consumers were not harmed by predatory behavior by the manufacturer, but by their own disinterest in choosing better sound systems: "The response of the antitrust laws is caveat emptor: if car purchasers do not comparison shop, that is their problem, so long as Chrysler is doing nothing to stop them." 410

The on-sale bar of patent law, under which inventors are prohibited from obtaining a patent on an invention that has been available for sale to the public for more than a year before the patent application is filed, raises a related concern. If the inventor offered a product for sale earlier than a year before filing, the public may be prejudiced because the inventor is allowed practically to profit from market exclusivity for a period that is longer than the statutory patent term. Was the "thing" offered the same as the "thing" patented? The question does not hinge on the metaphysics of the sale, since a "sale" of the thing may occur before the "thing" itself exists. As the Supreme Court noted in Pfaff $v$. Wells Electronics, ${ }^{411}$ which established that the one-year bar period begins to run when the invention is "ready for

econometrics"). See also supra note 160 and accompanying text (discussing product design).

408 Automatic Radio Mfg. Co. v. Ford Motor Co., 390 F.2d 113 (1st Cir. 1969). The lower court noted that plaintiff had plausibly argued that radios and automobiles continued to be distinct products, unlike "bumpers, hang-on fender lights, outside auto trunks and luggage racks which were in vogue decades ago," which "became parts of automobiles and lost their identities as accessories. Radios have retained their identity as separate products." Automatic Radio Mfg. Co. v. Ford Motor Co., 272 F. Supp. 744, 748 (D. Mass. 1967).

409959 F.2d 468 (3d Cir. 1992).

410 Id. at 489.

411525 U.S. 55 (1998) (explaining various types of information costs). 
patenting," 412 the question is primarily one of policy. Did the inventor appear to have been acting unfairly with regard to the legitimate interests of the public? $?^{413}$

Thing-by-policy is, therefore, the most comprehensive and flexible of the thing frameworks that the law uses. It can handle both enduring things and idiosyncratic things, things that touch all of us or things that concern only a few. Policy-makers can legitimately manipulate thingness to serve all or any of a range of policies, and can work the process in reverse, manipulating policy arguments to create or undermine thingness as the policy winds demand. That breadth, of course, is precisely the weakness of the model; despite their authoritative character in practice, that authority is no more legitimate than the conceptual policy apparatus that thingness serves at any given moment. Things are of the law, not of our lives. Thingness devolves into case-by-case examinations of relevant policies, from broad concerns over information, transaction, and/or fragmentation costs, ${ }^{414}$ to narrower concerns with incentives and attribution, to consumer concerns with price, quality, and autonomy, or to cultural interests in stability and cultural meaning. ${ }^{415}$ All of these concerns can be lumped into a policy-based theory of things, as Henry Smith does when he argues that the forms of property embody trade-offs between different communicative dimensions of property-ish things. ${ }^{416}$ Broad, lay audiences for things demand more formally defined property rights, which are easier to comprehend. Narrower, relatively expert audiences are better able to process more nuanced, contextual property rights, which take more time to comprehend. ${ }^{417}$ First sale in copyright and exhaustion in patent are manifestations of the former, for example; "what is a book"

412 Id. at 67.

413 Id. at 63-65.

414 See Merrill \& Smith, supra note 104, at 24-42 (discussing information costs); Heller, supra note 4, at 1187-1202 (discussing fragmentation).

415 On the policy benefits of durable thingness as such in the intellectual property realm, compare Keith Aoki, Adrift in the Intertext: Authorship and Audience "Recoding" RightsComment on Rober H. Rotstein, "Beyond Metaphor: Copyright Infringement and the Fiction of the Work," 68 CHI.-KENT L. REV. 805 (1993); Justin Hughes, "Recoding " Intellectual Property and Overlooked Audience Interests, 77 TEX. L. REv. 923 (1999); William M. Landes \& Richard A. Posner, Indefinitely Renewable Copyright, 70 CHI. L. REV. 471, 486-88 (2003) (all making policy-based arguments in favor of more durable thingness of copyrighted works), with Carter, supra note 376, at 723; Charlotte Hess \& Elinor Ostrom, Ideas, Artifacts, and Facilities: Information as a Common-Pool Resource, 66 LAW \& CONTEMP. PROBS. 111 (2003); David Rice, Copyright as Talisman: Expanding 'Property' in Digital Works, 16 INT'L REV. L. COMP. TECH. 113 (2002); Pamela Samuelson, Information as Property: Do Ruckelshaus and Carpenter Signal a Changing Direction in Intellectual Property Law?, 38 CATH. U. L. REV. 365 (1989) (all suggesting policy-based reasons for reducing thingness of intellectual property rights).

416 Smith, supra note 297.

417 See id. at 1111. 
is a function of what the law constructs as consumer needs, not what the law observes as consumer practices. ${ }^{418}$

With thing-by-policy, law simply makes up things as it goes along. But there is no prior reason why things should be cheap or easy, and our intuition may be precisely the opposite-that things are valuable precisely in proportion to their complexity or expense. Thing-bypolicy thrives as the kind of ex post descriptive exercise that pervades the law, strengthened by its flexibility and adaptability across domains and across time. But it is weakened necessarily by its failure to demand a connection to common experience.

\section{CONCLUSION}

The book is the paradigmatic thing in law and in culture. It exercises a unique authority, combining text and heft, concept and materiality. ${ }^{419}$ Taking things seriously means recognizing that authority in other material and conceptual forms, and searching for its sources. This is not Ahab's pursuing the white whale, only to find it and be destroyed. This is appreciation and respect for new forms of authority, and understanding its sources and its limitations. My argument can be summed up in the following three steps.

First, the law does not go far enough to recognize that things are important. The conventional account holds that people are important, and what people do with things are important, but things are not. But that is not so. There are debates in a variety of places in the law about "things"- how to define them, classify them, and define their legal implications-but the debates are often seen as proxies for debates about relationships and interests and policies. What interests me is the sense that the debates may really, in fact, be about things. Things play important roles in our lives but are underappreciated in the law, by virtue of Realist and post-Realist jurisprudence and scholarship. The literal and figurative reconfigurability of the world teaches us to appreciate the role of things in creating and exercising authority in law. We know this when we consider high technology and particularly computer technology. "Code" regulates much as law does. But this is more generally true of things, and we should look for and understand

418 See id. at 1175.

419 See supra note 343 . Scholars of text argue that books, as artifacts, cannot be understood independently of the institutions and communities, such as libraries, that interpret and ultimately order them. Books as material objects are therefore both critical and provisional, since their existence depends not on constructs of authors or texts, but on institutions and communities that surround them and are bound by them. See Geoffrey Nunberg, The Places of Books in the Age of Electronic Reproduction, 42 REPRESENTATIONS 13 (1993), reprinted in FUTURE LIBRARIES (Howard Bloch \& Carla Hesse eds., 1994). 
regulation-by-thing in all areas of thingness, rather than focusing our energy exclusively or largely on the artifacts of computer science.

Second, the law does not appreciate sufficiently that things do not just exist. Things come from somewhere, and after they arrive they change, and the law has a meaningful role to play in constructing things and managing their evolution. Thingness in the law is not simply given. It does not fall neatly into traditional legal categories such as "property" or "contract," or nonlegal categories such as "technology" or "the market." The law creates and enforces thingness, and creates and enforces the authoritative character of thingness, and it does so in a variety of ways. Exposing that variety takes some effort, as it requires crossing disciplinary boundaries both in law and elsewhere. But if the results enable us more clearly to see the character of authority in our lives, and both the virtues and drawbacks of that authority, then the effort is worthwhile.

Third, bringing transparency to the processes of thing-making and thing-changing yields a wealth of possibilities in terms of both conventional and unconventional legal regulation. Once we see that there are several different ways in which things are made, we see the possibility of different alternative regulatory universes in which things are given and then regulated, or regulated in various ways during the process of their construction. The very notion of thingness suggests the existence of a dividing line between what is unregulable and regulable. Interposing the legal construction of thingness suggests that this line can be moved depending on regulatory interests. Critiques of thingness, and policy analyses of problems that concern things in any sense, can and should draw on the multiple senses of created thingness in developing both theoretical and practical arguments. The literature contains arguments addressing the choice between "law or code" as regulatory substitutes, ${ }^{420}$ and arguments addressing "law and code" as complements. ${ }^{421}$ By taking things apart, we see that the tools for appreciating and using (or rejecting) thingness in any regulatory context are far richer than one might initially suppose. The five models reviewed here represent only a rough taxonomy. As I note at several points, the models overlap with one another and in some areas blend together. For analytic purposes, they are useful starting points. Any policy-maker may pick and choose, accept or reject, all or parts of each model or some of them, hopefully taking account of their respective strengths and weaknesses in the context of the regulatory

420 See Lawrence Lessig, The Law of the Horse: What Cyberlaw Might Teach, 113 HARV. L. REV. 501 (1999).

${ }^{421}$ See R. Polk Wagner, On Software Regulation, 78 S. CAL. L. REV. 457 (2005). 
question at hand. Distinguishing the models suggests different kinds of questions to ask and highlights the merits of different answers.

A failure to appreciate the thingness of things undervalues the benefits of thing-based authority. Thingness can be a good thing. ${ }^{422}$ It also undervalues the benefits of challenging thingness. Things are authority, and authority is power. The insistence on thingness and the refusal to enable the disassembly of things may have important distributive consequences, not only in intellectual property domains, ${ }^{423}$ but elsewhere, even in the processes of democracy. ${ }^{424}$ If things are embodied culture, then they should be subjected to all of the pressures that keep cultures vibrant. We need to value them and re-create them, take them apart and improve them, preserve them and share them. Excessive deference to "nature" or to "design," even if we challenge the identity and authority of the designers, does not do enough to assure that things themselves are part and parcel of the messiness of human existence. To focus too narrowly on producer interests, too narrowly on individual interests, or too abstractly on markets or on efficiency or "social welfare" misses the inevitably human, and humanistic, character of the problem. ${ }^{425}$

Modern materialism forces an integrated account of things that can and things that cannot be "physically and permanently" possessed. ${ }^{426}$ We have a universe of malleable cultural forms, some of which descend from accepted antecedents, many of which can be modified by practice and by law. The question for things is a broader form of the

${ }_{422}$ For example, in a recent article, Robert Merges proposed that Congress amend the Copyright Act to provide for enforcement of "limited copyright" notices of the sort promoted by the Creative Commons project. See Robert P. Merges, A New Dynamism in the Public Domain, 71 U. CHI. L. REV. 183, 201-02 (2004). Carol Rose argues that the material and interpretive flexibility of modern things means that law might affirmatively choose to create complex "things," in explicit contravention of an "information costs" principle that privileges simplicity, in order to distinguish things from mere commodities. See Carol M. Rose, Afterword: Whither Commodification?, in RETHINKING COMMODIFICATION, supra note 18, at 402-20.

${ }^{423}$ See Rubenfeld, supra note 145 at 3-5 (describing conflicts between copyright law and First Amendment principles); see also Joseph P. Liu, The DMCA and the Regulation of Scientific Research, 18 BERKELEY TECH. L.J. 501, 509-16 (2003) (describing scientists' criticism of the DMCA and its effect on certain computer science research).

424 See Online Policy Group v. Diebold, 337 F. Supp. 2d 1195 (N.D. Cal. 2004) (holding that developer of voting machine software misrepresented copyright claim under the DMCA as part of effort to discourage public posting of criticism of its technology).

${ }^{425}$ As Annelise Riles writes:

[I] $\mathrm{t}$ is the mundane technocratic dimensions of law, precisely those dimensions that fail to engage humanists' theoretical, critical, or reformist passions, that are the most interesting artifacts of lawyerly work. Hence it is time humanists take on the technical dimension of legal knowledge as a cultural practice of its own. ... [W] can do something other than ignore or critique the technocrats and the technologists in our midst: we can study them.

Riles, supra note 39, at 1029, 1033.

426 See William BlaCKSTONE, 2 COMMENTARIES * 14. 
narrow question raised by copyright and patent: what is the role of the law in preserving and shaping the forms that our "creative" institutions produce? That role is inevitable and essential. The answer cannot be found in critical or Realist arguments that the law must focus entirely on relationships and values in order to mitigate the concealed influence of power, ${ }^{427}$ or in economics arguments that the law should devise mechanisms so that the allocation of resources maximizes social welfare. ${ }^{428}$ There are contexts and methods for creating and legitimating thingness that do and should go unchallenged, so long as we fairly appreciate what they are. But abandonment of thingbased descriptions in favor of rights- and rules-based descriptions leaves us without a vocabulary adequate to capture actual human experience. Pragmatism cautions us to test propositions by their consequences in terms of human wants and needs rather than according to an ex ante ontology. The fluidity of things both conceptual and material challenges the pragmatist's premise, since we can no longer take assurance from modern law's relative distrust of the conceptual and trust of the material. ${ }^{429}$ The natural law tradition, which measures universal principles of truth and morality against "inherent characteristics in human beings and other animate things as well as in the physical word and in social structures, ${ }^{, 430}$ comes in for similar questioning. We cannot assume the truth of what is "inherent" and what is manufactured. Adjudication, legislation, and scholarship should make the bases of thingness more transparent, so that the sources and weight of authority can be better evaluated, and so that the tools thus discovered can be put to more effective use.

${ }^{427}$ See Morris R. Cohen, Property and Sovereignty, 13 CORNELL L.Q. 8, 12 (1927) (describing property as delegated sovereignty over others).

${ }_{428}$ See, e.g., RichaRd A. POSNER, ECONOMIC ANALYSIS OF LAW 14 (5th ed. 1998) (describing Pareto-optimality).

${ }^{429}$ See Riles, supra note 39, at 1022-23 (describing the transformation of legal form, in which a metaphor-law as a tool, or as a machine-is literalized in order to become a further tool) (citing ROY WAGNER, THE INVENTION OF CULTURE 42-44 (1975), on the "obviation" of symbolic practices, in which symbols come to stand for themselves, that is, actual material objects, and MARILYN STRATHERN, AFTER NATURE: ENGLISH KINSHIP IN THE LATE TWENTIETH CENTURY 194-95 (1992), who describes the literalization of previously metaphorical conceptual relations - the process of making explicit the implicit).

430 W. MichaEl REISMAN \& AaRON M. SCHREIBER, JURISPRUdENCE, UNDERSTANDING AND SHAPING LAW 170 (1987); see GEORGE WHITECHOSS PATON, JURISPRUDENCE 80 (2d ed. 1951) (referring to rules based on nature as beyond the power of man); see also LLOYD L. WEINREB, NATURAL LAW AND JUSTICE 1-7 (1987) (describing natural law as a theory about the nature of being, the human condition in particular). 